\title{
Platonism and Christian Thought in Late Antiquity
}

Platonism and Christian Thought in Late Antiquity examines the various ways in which Christian intellectuals engaged with Platonism both as a pagan competitor and as a source of philosophical material useful to the Christian faith. The chapters are united in their goal to explore transformations that took place in the reception and interaction process between Platonism and Christianity in this period.

The contributions in this volume explore the reception of Platonic material in Christian thought, showing that the transmission of cultural content is always mediated, and ought to be studied as a transformative process by way of selection and interpretation. Some chapters also deal with various aspects of the wider discussion on how Platonic, and Hellenic, philosophy and early Christian thought related to each other, examining the differences and common ground between these traditions.

Platonism and Christian Thought in Late Antiquity offers an insightful and broadranging study on the subject, which will be of interest to students of both philosophy and theology in the Late Antique period, as well as anyone working on the reception and history of Platonic thought, and the development of Christian thought.

Panagiotis G. Pavlos is Research Fellow at the Department of Philosophy, University of Oslo, Norway. His main interests are Late Antique metaphysics, cosmology and the early Christian philosophical tradition, with an emphasis on their interaction. His doctoral dissertation examines the concept of aptitude (epitêdeiotês) in Late Antique and Early Christian thought.

Lars Fredrik Janby holds a Ph.D. in the History of Ideas from the University of Oslo, Norway, where he defended a thesis on Augustine's encyclopedic project. His research focuses on Christian receptions of classical material in Late Antiquity.

Eyjólfur Kjalar Emilsson is Professor of Philosophy at the University of Oslo, Norway. His research interests include topics in metaphysics and ethics in the ancient and late ancient classical philosophical tradition. He is the author of four monographs and numerous articles on ancient philosophy, focusing on Plotinus in particular.

Torstein Theodor Tollefsen is Professor of Philosophy at the University of Oslo, Norway. His main interests are metaphysics and cosmology in late antiquity and early Byzantium, and the tensions and interactions between pagan and Christian thought in that period. 


\section{Studies in Philosophy and Theology in Late Antiquity}

Series editors: Mark Edwards

Christ Church College, University of Oxford, UK

Lewis Ayres

Durham University, UK

The Studies in Philosophy and Theology in Late Antiquity series focuses on major theologians, not as representatives of a 'tradition', whether Christian or classical, but as individuals immersed in the intellectual culture of their day. Each book concentrates on the arguments, not merely the opinions, of a single Christian writer or group of writers from the period AD 100-600 and compares and contrasts these arguments with those of pagan contemporaries who addressed similar questions.

By study of political, social, and cultural milieu, contributors to the series show what external factors led to the convergence or divergence of Christianity and pagan thought in particular localities or periods. Pagan and Christian teachings are set out in a clear and systematic form, making it possible to bring to light the true originality of the author's thought and to estimate the value of his work for modern times.

This high-profile research series offers an important contribution to areas of contemporary research in the patristic period, as well as providing new links into later periods, particularly the Medieval and Reformation.

\section{Clothed in the Body}

Asceticism, the Body and the Spiritual in the Late Antique Era

Hannah Hunt

Individuality in Late Antiquity

Edited by Alexis Torrance and Johannes Zachhuber

\section{Porphyry in Fragments}

Reception of an Anti-Christian Text in Late Antiquity

Ariane Magny

\section{Aristotle and Early Christian Thought}

Mark Edwards

\section{Platonism and Christian Thought in Late Antiquity}

Edited by Panagiotis G. Pavlos, Lars Fredrik Janby, Eyjólfur Kjalar Emilsson, and Torstein Theodor Tollefsen

For more information on this series, please visit: www.routledge.com/classicalstudies/ series/PTLATEANTIQUITY 


\section{Platonism and Christian Thought in Late Antiquity}

Edited by Panagiotis G. Pavlos, Lars Fredrik Janby, Eyjólfur Kjalar Emilsson, and Torstein Theodor Tollefsen 
First published 2019

by Routledge

2 Park Square, Milton Park, Abingdon, Oxon OX14 4RN

and by Routledge

52 Vanderbilt Avenue, New York, NY 10017

Routledge is an imprint of the Taylor \& Francis Group, an informa business

(C) 2019 selection and editorial matter, Panagiotis G. Pavlos, Lars Fredrik Janby, Eyjólfur Kjalar Emilsson, and Torstein Theodor Tollefsen; individual chapters, the contributors

The right of Panagiotis G. Pavlos, Lars Fredrik Janby, Eyjólfur Kjalar Emilsson, and Torstein Theodor Tollefsen to be identified as the authors of the editorial material, and of the authors for their individual chapters, has been asserted in accordance with sections 77 and 78 of the Copyright, Designs and Patents Act 1988.

All rights reserved. No part of this book may be reprinted or reproduced or utilised in any form or by any electronic, mechanical, or other means, now known or hereafter invented, including photocopying and recording, or in any information storage or retrieval system, without permission in writing from the publishers.

Trademark notice: Product or corporate names may be trademarks or registered trademarks, and are used only for identification and explanation without intent to infringe.

British Library Cataloguing-in-Publication Data

A catalogue record for this book is available from the British Library

Library of Congress Cataloging-in-Publication Data

Names: Pavlos, Panagiotis G., editor.

Title: Platonism and Christian thought in late antiquity / edited by Panagiotis G. Pavlos, Lars Fredrik Janby, Eyjólfur Kjalar Emilsson, and Torstein Theodor Tollefsen.

Description: First [edition]. | New York : Routledge, 2019. | Series: Studies in philosophy and theology in late antiquity | Includes bibliographical references and indexes.

Identifiers: LCCN 2019009051 (print) | LCCN 2019019524 (ebook) | ISBN 9780429440465 (ebook) | ISBN 9780429803109 (web pdf) | ISBN 9780429803086 (mobi/kindle) | ISBN 9780429803093 (epub) | ISBN 9781138340954 (hardback : alk. paper)

Subjects: LCSH: Platonists. | Christian philosophy—History—Early church, ca. 30-600.

Classification: LCC B517 (ebook) | LCC B517 P55 2019 (print) | DDC $184-\mathrm{dc} 23$

LC record available at https://lccn.loc.gov/2019009051

ISBN: 978-1-138-34095-4 (hbk)

ISBN: 978-0-429-44046-5 (ebk)

Typeset in Times New Roman by Apex CoVantage, LLC 


\section{Contents}

Acknowledgements vii

List of contributors viii

List of abbreviations $\quad \mathrm{xi}$

Introduction 1

LARS FREDRIK JANBY, EYJÓLFUR KJALAR EMILSSON, TORSTEIN

THEODOR TOLLEFSEN, AND PANAGIOTIS G. PAVLOS

\section{PART I}

Methodologies

1 The agreement of Christianity and Platonic philosophy from Justin Martyr to Eusebius

SÉBASTIEN MORLET

2 Augustine and the "prophecy" of Plato, Tim. 29c3

CHRISTINA HOENIG

3 Porphyry's daemons as a threat for the Christians

\section{PART II}

Cosmology

4 Patristic reflections on formless matter ENRICO MORO

5 Plotinus' doctrine of badness as matter in Ennead I.8 [51] 
vi Contents

6 Proclus, Philoponus, and Maximus: the paradigm of the world and temporal beginning

TORSTEIN THEODOR TOLLEFSEN

\section{PART III}

Metaphysics

7 Christ and Pythagoras: Augustine's early philosophy of number LARS FREDRIK JANBY

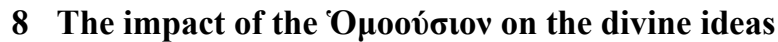
DANIEL J. TOLAN

9 Theurgy in Dionysius the Areopagite PANAGIOTIS G. PAVLOS

10 On the meaning of hierarchy in Dionysius the Areopagite DIMITRIOS A. VASILAKIS

11 The doctrine of immanent realism in Maximus the Confessor SEBASTIAN MATEIESCU

12 That and how perichōrēsis differs from participation: the case of Maximus the Confessor

JORDAN DANIEL WOOD

\section{PART IV}

Ethics

13 Apophaticism in the search for knowledge: love as a key difference in Neoplatonic and Christian epistemology

E. BROWN DEWHURST

14 The origin of passions in Neoplatonic and early Christian thought: Porphyry of Tyre and Evagrius Ponticus

ADRIAN PIRTEA

15 Augustine on eudaimonia as life project and object of desire TOMAS EKENBERG 


\section{Acknowledgements}

The idea of this volume was conceived in the aftermath of the International Workshop on the Philosophy of Late Antiquity held at the Department of Philosophy, Classics, History of Art and Ideas at the University of Oslo in December 2016, where some of the contributors presented papers. The aim of that project was to bring together scholars to discuss key issues on the encounter between Platonism and Christian thought in Late Antiquity. We would like to thank the Society for Ancient Philosophy at the University of Oslo, for their support.

We would like to extend our thanks to the Department of Philosophy, Classics, History of Art and Ideas at the University of Oslo for its generous support throughout the process of preparing this book. We are grateful also to the editors of the series 'Studies in Philosophy and Theology in Late Antiquity', Professors Lewis Ayres and Mark Edwards, for their faith in the volume and their valuable suggestions in the preparation of the manuscript and to the external reviewers for their warm welcome of the book and their comments.

Finally, we wish to express our gratitude to our Routledge editors, Amy DavisPoynter and Elizabeth Risch. They deserve special thanks for embracing this volume from the very first moment, securing its production, and working with us tirelessly to bring it into life. 


\section{Contributors}

E. Brown Dewhurst is currently an Adjunct Lecturer at Ludwig-Maximilians Universität München, Germany. Their research specialism is the relevance of Greek Patristics for contemporary ethical issues. They received their doctorate from Durham University on the topic of Maximus the Confessor, virtue ethics, and contemporary critiques of the nation state.

Tomas Ekenberg is a Docent of theoretical philosophy at Uppsala University, Sweden. He specialises in early medieval ethics, action theory, and moral psychology and their late ancient precursors. He has published several articles on Anselm of Canterbury's and Augustine's thought and co-edited the anthology Subjectivity and Selfhood in Medieval and Early Modern Philosophy (2016).

Eyjólfur Kjalar Emilsson is Professor of Philosophy at the University of Oslo, Norway. His research interests include topics in metaphysics and ethics in the ancient and late ancient classical philosophical tradition. He is the author of four monographs and numerous articles on ancient philosophy, focusing on Plotinus in particular.

Christine Hecht is working on Porphyry's Philosophia ex oraculis in the Collaborative Research Center 923 "Threatened Order - Societies under Stress" at the University of Tübingen, Germany (Department of Classics). Her research focuses on the interaction between Christians and pagan philosophers in the third and fourth century CE. She received her PhD from Tübingen in 2015.

Christina Hoenig is an Assistant Professor in Classics at the University of Pittsburgh, Pennsylvania, USA. Her research focuses on the Roman and Greek philosophical writers from the first century BC to Late Antiquity. One of her central themes of interest is the translation of Greek philosophical vocabulary into Latin. The larger part of her current research concentrates on the Latin Platonic tradition, especially on topics in natural philosophy and metaphysics.

Lars Fredrik Janby holds a Ph.D. in History of Ideas from the University of Oslo, Norway, where he defended a thesis on Augustine's encyclopedic project. His research focuses on Christian receptions of classical material in Late Antiquity. 
Sebastian Mateiescu is Associate Researcher at the Research Centre for Philosophy and Religious Studies-Institute of Ecumenical Studies (IÖFH) at the Lucian Blaga University of Sibiu, Romania. He has held research positions in philosophy in Bucharest and Lausanne. His interest centers around the reception of ancient philosophy and logic in Byzantine thought. Several of his publications highlight various philosophical aspects in the work of Maximus the Confessor.

Sébastien Morlet is Maître de Conférences at Sorbonne Université (Paris), France. His research interests include patristics, Late antique literature and history of ideas. His main publications are: La Démonstration évangélique d'Eusèbe de Césarée. Étude sur l'apologétique chrétienne à l'époque de Constantin, 2009; Christianisme et philosophie. Les premières confrontations (I ${ }^{e r}$ - VI $I^{e}$ siècle), 2014; Les chrétiens et la culture (Ier-VIe siècle), Paris, 2016; Symphonia. La concorde des textes et des doctrines dans la littérature grecque jusqu'à Origène, 2019.

Enrico Moro, Ph.D., is Research Fellow in Medieval Philosophy at the Department FiSSPa, University of Padua, Italy. Among his recent publications are: $I l$ concetto di materia in Agostino (2017) and Agostino, Commenti alla Genesi (2018, with Giovanni Catapano).

Panagiotis G. Pavlos is Research Fellow at the Department of Philosophy, University of Oslo, Norway. His main interests are Late Antique metaphysics, cosmology and the early Christian philosophical tradition, with an emphasis on their interaction. His doctoral dissertation examines the concept of aptitude (epitédeiotēs) in Late Antique and Early Christian thought.

Adrian Pirtea (Ph.D. 2017) is a Postdoctoral Researcher at the Chair of Byzantine Studies (Freie Universität Berlin, Germany) and at the Berlin-Brandenburg Academy of Sciences. His main area of interest is Late Antique, Byzantine, and Syriac Christianity. He is currently preparing his Ph.D. thesis for publication: The Spiritual Senses in East Syriac Mysticism and the Legacy of Evagrius Ponticus.

Daniel J. Tolan is the Academic Secretary to the Cambridge Centre for the Study of Platonism, UK, where he is writing up his doctoral thesis in the Cambridge Faculty of Divinity. He is a member of Clare College, University of Cambridge, UK.

Torstein Theodor Tollefsen is Professor of Philosophy at the University of Oslo, Norway. His main interests are metaphysics and cosmology in late antiquity and early Byzantium, and the tensions and interactions between pagan and Christian thought in that period.

Dimitrios A. Vasilakis received his Ph.D. from King's College London, UK (Neoplatonic Love: the Metaphysics of Eros in Plotinus, Proclus and the pseudoDionysius, 2014). He completed a post-doc in Ludwig-Maximilians-Universität, 
Munich, Germany (DFG-Project "Natur in politischen Ordnungsentwürfen"). As an independent scholar he writes articles on ancient Greek philosophy, especially Neoplatonism, and its reception in the Orthodox East.

Jordan Daniel Wood received his Ph.D. in Historical Theology from Boston College, USA (2018), where he wrote on the Christological metaphysics of Maximus the Confessor. He also conducts research in nineteenth-century German Idealism and its theological legacy among Catholics. He currently serves as Visiting Assistant Professor of Theology at Providence College, USA. 


\section{Abbreviations}

\section{Series and editions}

ANF The Anti-Nicene Fathers

CAG Commentaria in Aristotelem Graeca

CCSG Corpus Christianorum, Series Graeca

CCSL Corpus Christianorum, Series Latina

CSEL Corpus scriptorum ecclesiasticorum latinorum

GCS Die griechischen christlichen Schriftsteller der ersten Jahrhunderte.

GNO Gregorii Nysseni opera. Ed. Werner W. Jaeger et al. 10 Vols. Leiden: Brill, 1921-2009

LCL Loeb Classical Library

LSJ A Greek-English Lexicon. Ed. Henry G. Liddell and Robert Scott.

Revised by Sir Henry S. Jones. With a Revised Supplement. Oxford:

Clarendon Press, 1996

PG Patrologiae cursus completus: Series graeca. Ed. Jacques-Paul Migne. 162 vols. Paris: Imprimerie Catholique, 1857-1886

PL Patrologiae cursus completus: Series latina. Ed. Jacques-Paul Migne.

217 vols. Paris: Imprimerie Catholique, 1844-1864

PTS Patristische Texte und Studien

SBLGNT Greek New Testament. Society of Biblical Literarure

SC Sources chrétiennes

TLG Thesaurus linguae grecae

\section{Texts}

(Only authors whose works appear frequently are abbreviated.)

\section{AMBROSE}

Exam.

Exameron

ARISTOTLE

Cat. 
xii Abbreviations

Met.

Metaphysica (Metaphysics)

Phys.

Physica (Physics)

Pol.

Politica (Politics)

\section{ATHANASIUS OF ALEXANDRIA}

C. $A r$.

C. Gent.

Decr.

Inc.

Syn.

\section{ATHENAGORAS}

Leg.

\section{AUGUSTINE}

C. Faust.

Civ. Dei

Conf.

Cons. ev.

Doctr. Chr.

Lib. arb.

Retr.

Trin.

\section{BASIL THE GREAT}

Ep.

Hex.
Contra Arianos (Against the Arians)

Contra Gentes (Against the Heathen)

De decretis (Defense of the Nicene Definition)

De incarnatione Verbi Dei (On the Incarnation)

De synodis (On the Synods)

Legatio pro Christianis (Embassy for the Christians)
Contra Faustum Manichaeum (Against Faustus the Manichean)

De civitate Dei (The City of God)

Confessiones (Confessions)

De consensu evangelistarum (On the Agreement of the Evangelists)

De doctrina christiana (On Christian Doctrine)

De libero arbitrio (On Free Will)

Retractationes (Revisions)

De Trinitate (On the Trinity)
Epistles

Homiliae in Hexaëmeron (Homilies on the Six Days of Creation)

\section{CLEMENT OF ALEXANDRIA}

Paed.

Pr.

Str.
Paedagogus (Christ the Educator)

Protrepticus (Exhortation to the Greeks)

Stromateis (Stromata or Miscellanies)

DIONYSIUS THE AREOPAGITE

$C D$

$D N$

$\mathrm{CH}$

EH

MT

Ep.
Corpus Dionysiacum Areopagiticum

De divinis nominibus (On the Divine Names)

De caelesti hierarchia (On the Celestial Hierarchy)

De ecclesiastica hierarchia (On the Ecclesiastical Hierarchy)

De mystica theologia (On Mystical Theology)

Epistulae (Letters) 


\section{EUSEBIUS OF CAESAREA}

$P E$

\section{EVAGRIUS}

Cogit.

Disc.

Eulog.

Gnost.

$K G$

Oct. Spir.

Or.

Pract.

Schol. Iob

Schol. Prov.

Schol. Ps.

\section{GREGORY OF NYSSA}

In Hex.

\section{IAMBLICHUS}

De Myst.

\section{JOHN PHILOPONUS}

Arbit.

Contra Proclum

In Cat.

In Phys.

Praeparatio evangelica (Preparation for the Gospel)

De malignis cogitationibus (On Thoughts)

Capita cic auctoribus discipulis Euagrii (Chapters of the Disciples of Evagrius)

Tractatus ad Eulogium (Treatise to Eulogius)

Gnosticus (The Gnostic or The One Worthy of Knowledge)

Kephalaia Gnostica (Chapters on Knowledge)

De octo spiritibus malitiae (On the Eight Spirits of Wickedness)

De oratione (Chapters on Prayer)

Practicus (Treatise on the Practical Life)

Scholia in Iob (Scholia on Job)

Scholia in Prouerbia (Scholia on Proverbs)

Scholia in Psalmos (Scholia on Psalms)

Apologia in Hexaemeron (Apology to the Six Days of Creation)

De mysteriis Aegyptiorum (On the Egyptian Mysteries)

Arbitrator (Arbiter or Umpire)

De aeternitate mundi contra Proclum (Against Proclus' On the Eternity of the World)

In Aristotelis categorias commentarium (Commentary on Aristotle's Categories)

In Aristotelis physicorum octo libros commentaria (Commentary on Aristotle's Physics)

\section{JUSTIN MARTYR}

Ap.

Dial.
Apologia (Apology)

Dialogus cum Tryphone (Dialogue with Tryphone)

\section{MAXIMUS THE CONFESSOR}

Amb. Io.

Amb. Th.
Ambigua ad Iohannem (Difficult Passages Addressed to John)

Ambigua ad Thomam (Difficult Passages Addressed to Thomas) 
xiv Abbreviations

Car.

$D P$

Ep.

Myst.

Opusc.

Or. dom.

Q. Thal.

Th. oec.
Capita de caritate (Centuries on Love)

Disputatio cum Pyrrho (Dispute with Pyrrhus)

Epistulae (Letters)

Mystagogia (Mystagogy)

Opuscula theologica et polemica (Small Theological and Polemical Works)

Expositio orationis dominicae (Commentary on the Lord's Prayer)

Quaestiones ad Thalassium (Questions Addressed to Thalassius)

Capita theologica et oeconomica (Chapters on Theology and the Economy)

\section{ORIGEN}

C. Cels.

Contra Celsum (Against Celsus)

Comm. in Io.

Commentarium in Iohannem (Commentary on John)

Comm. in Matt.

Commentarium in Evangelium Matthaei (Commentary on Matthew)

Dial. Her.

Dialogus cum Heraclide (Dialogue with Heraclides)

Hom. In Gen.

Homiliae in Genesim (Genesis Homilies)

Princ.

De principiis (First Principles)

\section{PHILO OF ALEXANDRIA (JUDEAUS)}

Immut.

Leg. All.

Migr.

Opif.
Quod Deus sit immutabilis (On the Unchangeableness of God)

Legum allegoriae (Allegorical Interpretation)

De migratione Abrahae (On the Migration of Abraham)

De opificio mundi (On the Creation)

PLATO

$\begin{array}{ll}\text { Gorg. } & \text { Gorgias } \\ \text { Leg. } & \text { Leges (The Laws) } \\ \text { Parm. } & \text { Parmenides } \\ \text { Phaed. } & \text { Phaedo } \\ \text { Phaedr. } & \text { Phaedrus } \\ \text { Phileb. } & \text { Philebus } \\ \text { Pol. } & \text { Politicus (Statesman) } \\ \text { Rep. } & \text { De Republica (The Republic) } \\ \text { Soph. } & \text { Sophista (Sophist) } \\ \text { Symp. } & \text { Symposium } \\ \text { Theaet. } & \text { Theaetetus } \\ \text { Tim. } & \text { Timaeus }\end{array}$




\section{PLOTINUS}

Enn.

PORPHYRY

Ad Marc.

Comm. in Ptol. Harm. In Harmonica (Commentary on Ptolemy's Harmonics) De abst.

In Cat.

Isag.

Phil. ex orac.

Sent.

Vit. Pl.

\section{PROCLUS}

De mal. subs.

El. theol.

In Alcib.

In Parm.

In Remp.

In Tim.

Theol. Plat.
Enneads

De abstinentia (On Abstinence from Killing Animals) In Categorias (Commentary in Aristotle's Categories) Isagoge (Introduction)

De philosophia ex oraculis haurienda (Philosophy from the Oracles)

Sententiae ad intelligibilia ducentes (Starting-points leading to the Intelligibles)

Vita Plotini (The Life of Plotinus)
De malorum subsistentia (On the Existence of Evils) Institutio theologica (The Elements of Theology) In Alcibiadem (Commentary on [Plato's] Alciviades I) In Parmenidem (Commentary on Plato's Parmenides) In rem publicam (Commentary on Plato's Republic) In Timaeum (Commentary on Plato's Timaeus) Theologia Platonica (Platonic Theology)

\section{THEOPHILUS}

Aut. 
$\Longrightarrow$ Taylor \& Francis

Taylor \& Francis Group

http://taylorandfrancis.com 


\title{
Introduction
}

\author{
Lars Fredrik Janby, Eyjólfur Kjalar Emilsson, \\ Torstein Theodor Tollefsen, and Panagiotis G. Pavlos
}

This volume is about the complex relationship between Platonism and Christian thought in Late Antiquity. Rooted in the pagan world, Platonism was perceived by Christian intellectuals as a competitor to the faith in the religious and intellectual market, while also representing a rich source of philosophical material that could be appropriated in their own rational inquiries. Christian receptions of Platonism therefore oscillated between rejection and appropriation, and it is the inner workings of that multifaceted relationship which is the subject of this book. The chapters are united in their goal to explore transformations that took place in the reception and interaction process and to discuss aspects of the relationship between Platonism and Christianity in Late Antiquity. In dealing with cases of reception of Platonic material in Christian thought, the contributions of this volume show that transmission of cultural content is always mediated, and ought to be studied as transformations that occur by way of selections and interpretations. Exploring the transformations that took place in the reception of Platonism in early Christian thought, these chapters study various ways in which Christian intellectuals engaged with Platonism both as pagan competitors and as a source of philosophical material useful to the Christian faith. The contributions also deal with various aspects concerning the general discussion on how Platonic/Hellenic philosophy and early Christian thought related to each other, examining the differences and common ground between these traditions.

With the rise of Christianity in the Greco-Roman world and its increasing worldly success, it was perhaps inevitable that Christian intellectuals would engage with the schools of ancient philosophy. In fact, Christianity was from its very beginning embedded in the intellectual discourse of the Greco-Roman world. The use of philosophical terms and conceptions in Christian literature that originated with Hellenic culture is as old as the Christian movement itself. Beginning with the New Testament, early Christians used philosophical language to communicate their beliefs. Paul's speech on the Areopagus was for example an intervention into the discourse of the hegemonic intellectual milieu of the time, using philosophical discourse in order to make himself understood and to appear convincing to his audience of pagan intellectuals. Here we encounter for the first time the idea that the message of the faith could be translated 


\section{Lars Fredrik Janby et al.}

into a language, which until then had been the exclusive property of pagan intellectuals. If Paul's appeal was addressed to intellectuals outside the faith, later Christians would also engage with ancient philosophy for the sake of rational inquiries in their own right.

Among the philosophical schools of Antiquity, it was however with Platonism that early Christianity would experience its most creative and enduring intellectual encounters. The Christian receptions of Platonism were facilitated by their shared fortunes, as the formation of early Christian thought coincided with the revival of Plato's dogmatic philosophy in the first centuries CE. As Christianity gained a foothold in late ancient society, it also increasingly started to engage with the intellectual discourses of the Greco-Roman world - a world in which the late Platonic movement was becoming a leading intellectual force. While the Platonic movement interpreted and systematised the teachings of Plato, the Christian thought was intent on interpreting and systematising the faith. Both movements showed themselves to be open to appropriating material from other systems. Just as the Platonic movement integrated material from Stoic and Peripatetic philosophy, the intellectual inquiries of the Christian movement engaged with the philosophical traditions of the Greco-Roman world, in various ways. Christian receptions of Platonic philosophy were multifaceted, spanning from complete rejection to conditional approval. This complex relationship was not specific to Platonism, but reflects the attitudes of early Christian culture to Hellenic philosophy in general. We can therefore not speak of a uniform transmission from Platonism to Christianity, only a wide range of strategies employed when material was transported from one context to another. The chapters of this volume are case studies of this process. If our introduction lines up some of the methodological principles, case studies are required to explore the phenomenon in detail.

The concepts "influence" and "legacy" have been subjected to much criticism over the past few decades. This is because they may conceal the agency that necessarily is involved in appropriation. Whatever the intellectual legacy of ancient philosophy, reception necessarily includes an active interpretation of the appropriated material. There can have been no direct transmissions of that material, only transfers which necessarily involved selection and mediation from one context to another. In our view, Christian intellectuals ought therefore to be seen as agents of transmission in the reception process - an aspect which may become obscured when we speak about "influence" or "legacy." If the philosophical material that we discover in Christian texts can be identified as having a Platonic provenance, that material may appear in response to questions foreign to the Platonic tradition, for example situated in contexts that pertain to intellectual inquiries into the Christian faith or other issues motivated by a human, rational curiosity. Reception is therefore always already mediated since it is molded by the horizon of the receiver, bestowing a meaning upon the material determined by contexts. When used as a response to Christian questions, the Platonic material was re-situated and transformed in accordance with Christian values and purposes. To study the transfer of philosophical concepts and theories from 
a pagan to a Christian context is to study how that material was transformed. Therefore, a number of contributions in this volume examine the creative aspects in which Christian thinkers engaged with Platonic material, exploring how the Platonic legacy was transformed in Christian contexts. In tracing this transmission, these contributions examine how a certain concept or doctrine changed meaning in the course of transmission, as it was uprooted from one context and placed into another - from the problems related to the Platonic worldview to the questions relevant to the Christian tradition. This methodology, analyzing the movement of material from one context to another (from a pagan to a Christian context), enables us to assess Christianity in relationship to Platonism. What did Christian intellectuals in Late Antiquity find useful in the Platonic tradition? Which changes did the material undergo with the swap of contexts? In turn, this approach also makes visible what Christian writers did not find to be of value in Platonism. What did Christians ignore or reject in the Platonic tradition? Reception studies are therefore expedient for inquiring into the dividing lines between paganism and Christianity.

Transformations aside, could the Christian appropriations of Platonic philosophy meaningfully be said to constitute a development of the Platonic tradition? In a famous essay, Heinrich Dörrie contended that Christian appropriation of Platonic material amounted to a de-platonisation. ${ }^{1}$ According to Dörrie, in the cases where material was uprooted from a Platonic context and inserted into a Christian one, the essentials of Platonism were eo ipso purged, effectively accomplishing a de-platonisation in the process. We think, however, that Dörrie's claim rests on a somewhat narrow definition of what tradition is. Examining how Platonic material was continued and transformed in Christian contexts, we submit that this volume can also meaningfully be said to be a contribution to studies on the development of the Platonic tradition. It has occasionally been discussed in scholarly literature whether Platonic philosophers were receptive to influences from the Christian movement. It is however not development in that sense which we here refer to. Rather, we claim that Christian transformations of Platonic material itself amount to a development of the Platonic tradition. Tracing the "afterlife" of Platonic material in Christian writers is to explore how Platonism continued to be used in intellectual inquiries into subjects that were unknown to the Platonic philosophers. In several cases, Christians developed the Platonic tradition in new and unexpected ways, asking new questions to the tradition that they engaged with and using it for problem-solving that was unknown to the Platonists themselves. From this point of view, it can meaningfully be said that the Platonic tradition was subject to development from the Christians. In this way, Christian intellectuals contributed to transform and disseminate the Platonic tradition, transporting its material into new areas of intellectual thought. The appropriations would therefore be a development of the Platonic tradition, albeit within a Christian frame that could not identify itself with pagan philosophy. The receptions of Platonic material in Christian thought are therefore relevant to the studies of the development of both the Platonic and the Christian tradition. 


\section{Christian methodologies}

Some observations on Christian intellectuals' own methodologies might also be in order here. First, there was no lack of endorsements of Platonic philosophy among early Christians, including acknowledgements that the Platonists had come close to the truth. Even the mature Augustine, for example, could claim that no other philosophical school had come closer to the Christian doctrine than the Platonists. ${ }^{2}$ With such statements, the usefulness of Platonic doctrines and concepts were given an explicit endorsement. Based on the perceived similarities between Platonism and Christianity, Christian intellectuals also willingly appropriated Platonic material for their own purposes. But which methodological principles did they themselves use when engaging with the Platonic material; how did they reason about their appropriation of material from Platonic philosophers? This is the subject of Part I of this volume, which deals with Christian methodologies and rhetorical strategies in the encounters with Platonic material.

There was a long-standing Christian discourse on Hellenic culture that had established some methodological principles for how Christians rightfully could engage with pagan material and use it for their own ends. The arguably most famous expression of this methodology is found in the application of the verse in Exod 12:35-36, in which the Israelites were asked to plunder the silver, gold, and clothing of the Egyptians on their way to the promised land. According to these methodological principles, the truth necessarily belonged to Christianity, and therefore all truth rightfully had to be considered Christian truth. From the viewpoint of Christian intellectuals, the use of Platonic material was therefore not seen as appropriation, but was justified and explained as re-appropriation. Based on the principle of "fair use" (usus iustus), the intellectual heritage of Hellenic culture could be integrated into Christian culture with only small modifications. ${ }^{3}$ From this perspective, Hellenic philosophy was still considered as lacking or false, but nonetheless, it justified the practice of using in their own rational inquiries elements from Hellenic philosophy that was perceived to be in agreement with Christian teachings. If something true was found in Plato or in the later Platonic tradition, then it had to be reckoned as a truth belonging to Christianity. Acknowledgement of Platonism was thus not an acknowledgement of intellectual debt, but a purification of truth from the falsehood of paganism. To appropriate material from a pagan context to a Christian one, was equal to removing any disturbing or false elements from the truth; to engage with Plato was to purify the unclean and put it into its appropriate context. In the first chapter of this volume, Sébastien Morlet inquires into this methodology of early Christian intellectuals, examining how key figures like Origen, Clement of Alexandria and Eusebius viewed the agreements and disagreements between Platonism and Christianity. This reveals the rich discourse established in early Christianity for how to deal with the apparent truths, which could be found in Platonic writings.

Another methodological strategy was that of casting Plato and his philosophy, which arguably had anteceded Christianity in the chronological order, as a "preparation" for the Gospels. Clement of Alexandria was one of the first writers to view 
Hellenic philosophy as preparation for Christianity - the Greek philosophers had anteceded the Gospels, but only with Christ, the incarnated Word, did the truths of Hellenic philosophy find their fulfillment. This methodology effectively offered an intellectual resolution to the dual relationship toward the philosophical tradition: by being assigned a preparatory role, Hellenic philosophy was conceded a certain part in the truth, while at the same time being kept at a distance from the truth itself because it did not take part in Revelation. As preparation, Hellenic philosophy was never sufficient in itself, but would need Christianity for its partial truths to find their fulfillment. Christians could in this way acknowledge the achievements of rational analysis and the relative merits of Plato and the later Platonic tradition without conceding to Platonism knowledge of the essential truths, which only had been communicated to human beings with Revelation. In accordance with this strategy, Hellenic philosophy was incorporated within history, and Platonism could be given a position in preparing the ground for the Christian faith. Relegated to preparation and introduction, Hellenic philosophy would always remain outside of salvific knowledge. This methodology was suitable to justify the appropriation of philosophical material in a selective way, whenever something was found that was in accordance with the faith. In her chapter, Christina Hoenig explores the strategy employed by Augustine in using Plato as a pseudo-prophet against later Platonists. By reference to metaphysical and epistemological language from the Timaeus, Augustine argues that Plato anticipated the human-divine relationship that was revealed through the Gospel - a strategy by which, as Hoenig shows, Augustine pits Plato against the current-day Platonists who refuse to acknowledge the incarnated Word. Plato had perhaps not grasped the role of the mediator, but he evidently understood a lot more than his arrogant inheritors, Augustine argues.

We ought not to forget that there existed a relationship of competition between Platonism and Christianity in Late Antiquity - Platonism was not only perceived as a rival in intellectual matters that sometimes erred in its rational inquiries, but as a movement that itself had religious qualities (or at any rate was perceived to have such qualities in the religious landscape of the period). Platonic philosophy was committed to inquire by rational means into the principles of reality, but it also held these highest principles to be divine. Plotinus added an element of spiritual mysticism to his interpretation of Plato's philosophy, and later Neoplatonists only reinforced this vein of spiritual or religious sentiment to the Platonic tradition in Late Antiquity. Any modern bifurcation between philosophy and religion was non-existent, and hence Christians naturally perceived Platonism as a religious competitor. The Platonism of Late Antiquity must have been seen by Christians as a religion on its own, committed to a philosophy that offered salvation. Platonism might even have competed with Christianity on the universal salvation of human beings, as seen for example in the works of Porphyry. ${ }^{4}$ The philosopher from Tyre remained a perennial foe to the Christian faith. In her chapter, Christine Hecht explores Eusebius' reception of Porphyry's daemonology. The daemons were a part of the inventory of the classical world that caused much distress to the Christian system - Christ had of course come to break the chains 
of the daemons and free human beings from their evil influence. Hecht shows the rhetorical aims involved in Eusebius' representation of Porphyry's daemonology, which often distorted what seem to have been the philosopher's original claims about the daemons.

\section{What did Christians find useful in Platonism?}

In general terms, Platonism had an enabling effect on the early Christian tradition. It was enabling in the sense that it provided Christians with an intellectual apparatus that allowed for new and advanced interpretations of beliefs and doctrines, providing a philosophical system consisting of terms and conceptions that could be integrated as means to interpretations and problem-solving within the faith. This claim is of course, to some degree or another, valid for all ancient schools of philosophy, and there were certainly also other philosophical traditions that made their influence on early Christian thought, such as Stoicism, for example. However, it is likely correct to say that among the philosophical schools of Antiquity, it was with the Platonic tradition that Christian intellectuals enjoyed the most creative and enduring relationship. A correspondence between Plato's philosophy and the Christian religion was observed by several Christian thinkers in Late Antiquity. Augustine could even claim that the extent of agreement between two movements was so large that the difference mainly was a matter of words. ${ }^{5}$ Sympathetic reading of Plato's writings could extend further than expected, surprisingly even into areas of Christian doctrine in which there was widespread acknowledgement that Platonic philosophy diverged from the faith: in his Stromateis, for example, Clement of Alexandria speculated that the myth of Er in Plato's The Republic is an allusion to the resurrection of the body; ${ }^{6}$ Justin Martyr was even willing to believe that the letter chi (X) which Plato in the Timaeus held to be the shape of the world soul, was a reference to the cross of Christ. $^{7}$

Within which areas of philosophy were early Christians most likely to perceive common ground with the Platonists? It seems that the observation of a widespread appropriation of Platonic philosophy in Christian thought requires an explanation. How do we explain the relative appeal of Platonism to Christian thought? What was it about Platonic philosophy - in comparison to other philosophical schools in antiquity - that made it seem so useful to Christians in their intellectual inquiries? Evidence suggests that metaphysics is the area in which early Christians tended to find the most extensive agreements between the faith and Platonic philosophy. ${ }^{8}$ What the two movements have in common is the belief that the world depends on the absolute reality of a divine being, since also Christians could think of the principles of the cosmos as keeping place in an invisible realm unavailable to the senses. The Platonic doctrine that there is a primary reality that exists prior to the physical world that we can apprehend with our senses, was easily integrated into the Christian distinction between God the creator and the created world, although there were differences in how they saw generation or creation to have taken place. Adopting Platonic discourse, Christians acquired a way to articulate the chasm between Creator and creation by using distinctions 
such as invisible/visible, permanence/becoming, and the novel uncreated/created, essence/activity.

More broadly, Christianity did find much common ground with the metaphysical inquiries of ancient philosophy. Ancient philosophy had always been committed to inquire into the principles of reality, and this was a philosophical discourse into which Christian intellectuals willingly entered. One of the main objections against Hellenic philosophy was the status of the cosmos, which Christians held to have been created from nothing (creatio ex nihilo) with a temporal beginning. In their arguments against the Hellenic philosophers, Christian intellectuals attempted to show that the principle of reality that the philosophers had been searching for is the Christian God, who is the ultimate cause that has generated the cosmos. Here, however, Christian interpreters could find a philosophical ally in Plato. Christian engagement with Platonist metaphysics had Plato's Timaeus as its main text the work had a formidable history of reception in Christian literature, which was anticipated by Philo of Alexandria, who already had made use of the Timaeus in his interpretation of Genesis. ${ }^{9}$ For later Christian writers too, the cosmogonic explanation given in the Timaeus largely agreed with the creation account in Genesis. In the cosmogonic account presented in the Timaeus, the demiurge is held to be the superior principle of generation, shaping the cosmos after the Forms. Its goodness is not inherent to the cosmos itself, but arranged from the outside. In the Christian perception, the Timaeus story nicely fitted with the key doctrine that the cosmos is created - and not eternal, as ancient philosophy otherwise would have it to be. While there were various interpretations of the demiurge within the Platonic tradition, Christians agreed with the idea that the cosmos is generated by a divine principle, that is, an active principle of generation, which otherwise could not be found in the other philosophical schools. According to this interpretation of the cosmogony in the Timaeus, Christians could establish common ground with Platonism with regard to the generation of the world.

Part II of the volume is focused on cosmology. Beside philosophical inquiries into the fundamental principles of reality, cosmology in the Platonic tradition also dealt with matter. Being either a preexisting something or the last phase of emanation void of form, matter remained somewhat of an "embarrassment" to the spiritual and moral aspirations of the Platonic philosopher, but none the less a subject worthy of analysis. Moreover, it held an indisputable position within the Platonic movement, since Plato had dealt with matter in the Timaeus - although in a way that left much room for interpretations by the later tradition. Matter was also subject to reception in early Christian thought, as shown by Enrico Moro in "Patristic reflections on formless matter." The doctrine of creation had a prominent standing within Christian theology. Christians did of course take a positive view on creation, which they held to be the product of the creator God in Genesis. But where did matter fit in this picture? Moro analyses the Platonic concept of prime matter in early Christian thought, showing how this concept could be employed in inquiries into Genesis and the creation of the world, enabling new interpretations of Scripture. However, reception can differ from the original: in his chapter "Plotinus' doctrine of badness as matter in Ennead I 8 (51)," Eyjólfur Kjalar 
Emilsson examines Plotinus' claim that matter is absolute badness. Plotinus held that matter, since it is devoid of form, being and goodness, must be responsible for bad things for living bodies, such as illness, poverty, and vice in souls. The chapter discusses Plotinus' explanation as to how badness is related to matter, and moreover puts into perspective the receptions that Moro analyses in the preceding chapter (as well as other aspects of Christian reception of Plotinus). ${ }^{10}$

One of the fundamental divergences between Platonism and Christian thought is the question about the provenance of the world. For the Platonist, the cosmos is eternal, and any notion of creation would amount to nothing other than the formation of a preexisting material. In other words, for the Platonists the basic principle of cosmology is "order out of chaos." For the Christian, though, the cosmos was not always there. It has been created out of nothing. Implicit at the beginnings of Christianity, or explicit after the contributions of the Cappadocians, the doctrine of creatio ex nihilo established one of the central distinctions between Platonic and Christian thought. This issue is treated by Torstein Theodor Tollefsen, who compares the cosmological doctrines of the Neoplatonist Proclus with the Christian doctrine of John Philoponus and Maximus the Confessor. For the Neoplatonists the world has always existed, since the paradigm, according to which it is created, is eternal. Against this view, the Christians claimed that the world has a beginning a definite number of time-units ago. The world is created from nothing, by the will of God, and it is created "recently," as said by Maximus. Tollefsen's chapter has two foci: The author treats first the Alexandrine Christian philosopher John Philoponus' critique of the Neoplatonist Proclus' cosmology. Then he focuses on Maximus the Confessor's doctrine of creation and asks whether one may detect any influence on Maximus from Philoponus.

Part III of the volume contains chapters addressing Christian receptions of Platonic metaphysics. Lars Fredrik Janby examines the philosophy of number in Augustine's early works. The chapter argues that this aspect of Augustine's philosophy must be read in context with the intellectual problems that occupied him at the beginning of his career as a writer. To that effect, the chapter considers the conceptual pair sensible and intelligible number, and its relation to the idea that the transient physical world reflects immutable, eternal unity. The chapter also investigates the fortunes of Augustine's philosophy of number in later writings, inquiring into how his perceptions about cognition of number changed. In his chapter, Daniel J. Tolan examines the role of the doctrine of the divine ideas in Christian and Platonic orthodoxy. Tolan shows how divine exemplarism was useful in defending divine simplicity, allowing Christian intellectuals to consider the created world as a temporal image of divine ideas, which are outside of time. Tolan's chapter draws on a number of sources to investigate the development of this doctrine and the various intellectual issues it confronted, including Plato's Timaeus, Philo of Alexandria, Clement of Alexandria, Origen, Plotinus and, finally, Athanasius.

Panagiotis G. Pavlos' chapter aims at offering insights on Dionysius the Areopagite's notion of theurgy. Pavlos takes over the remark that despite the linguistic affinities and terminological appropriations - whether Iamblichean or Procline - Dionysius' premises on the matter remain radically different from that 
of Neoplatonism, both in terms of the sacramental tradition he recapitulates and the wider Christian metaphysical contours he adheres to. He examines Dionysian theurgy both with respect to the metaphysical principles that connect with $\theta \varepsilon o v \rho \gamma i \alpha$ and the particular sacramental reality that emerges from it. Dimitrios A. Vasilakis examines the notion of hierarchy in Dionysius the Areopagite. In contrast to its modern usage, Dionysian hierarchy does not primarily refer to stratification or rank of power. Vasilakis focuses on the definition of hierarchy from Dionysius' Celestial Hierarchy with the aid of relevant passages from the Ecclesiastical Hierarchy. He explains how hierarchy relates to order, i.e. in what way hierarchy is a well-ordered system of entities, where one can indeed detect stratification. Through this ordering the higher entities (in the case of the Church: the hierarchs, the priests and their deacons) help the lower ones (the laity) to reach God, i.e. deification, as far as possible to each of them, through the sacraments of the Church. Hierarchy's last trait is understanding, which should not be understood merely intellectually, but erotically, as Vasilakis shows.

The Neoplatonist reception and development of Aristotelian logic had a great impact on Christian thought. Sebastian Mateiescu's chapter focuses on how this kind of logic served the theologians especially in the Christological controversy. Theological inquiries into the philosophical problem of the universals grew after the Council of Chalcedon (451). Maximus the Confessor presented an alternative to nominalism with respect to the species that the Miaphysite/antiChalcedonian theologians shared with several philosophers. As Mateiescu argues, this alternative can be labelled immanent realism. Influenced by Ps.-Dionysius the Areopagite, Maximus innovatively combines principles within logic and metaphysics in elaborating this doctrine. It is well known that participation is a central concept in Neoplatonist as well as in Christian systems of thought. However, in his chapter Jordan Daniel Wood shows that the Christians, in casu Maximus the Confessor, needed to develop this notion of how entities relate to one another with the idea of perichōrēsis or mutual interpenetration. This topic is especially relevant for issues in Christology and the Christian doctrine of deification. On the background of Cappadocian trinitarian theology and Christology, Maximus elaborates a perichoretic logic that pertains to the relation between God and the world in eschatology (i.e. deification), effectuating an identity that goes beyond the Neoplatonic participation.

While receptions of metaphysics and cosmology perhaps were more frequent, there are interesting issues related to the field of moral theory as well when studying the intersection between Platonism and Christian thought. Any Platonic proclivity to value the sensible world lower than the higher realm could moreover be paired with Christian moralists' call to contempt for the pleasures of this world, since both valued the physical world lower than the eternal, invisible source on which it depends. Part IV of the volume covers aspects of Christian moral theory in relation to Platonism. E. Brown Dewhurst compares notions of knowledge of the divine in the works of Maximus the Confessor and Proclus. Contrasting different aspects of their thought such as nature, providence, and apophaticism in relation to knowledge, the chapter concludes that knowledge for Maximus always 
is rooted in relationality - a notion which is rather absent in the Neoplatonic philosopher. A fundamental difference between Proclus and Maximus in this respect is found to be notable in the way that divine disclosure of knowledge bridges the gap between God and human beings in Maximus' theology. It is above all the union of Christ's humanity and divinity, the chapter argues, which makes the quest for knowledge into a relationship of love with the divine that is incompatible with Proclus' metaphysics. Adrian Pirtea examines the formation of passions in Porphyry and Evagrius, exploring some possible connections between the philosophical treatises of Plotinus' illustrious student and the ascetic writings of the Christian ascetic author. Porphyry has rarely been considered as a source of Christian ethics, but through a close reading of key passages in their works, Pirtea argues that Evagrius' theory of passions has much in common with the philosopher from Tyre - more so than with the Stoics, which often have been held to be the source of this theory. As Pirtea shows, both Porphyry and Evagrius show an interest in explaining how the passions originate from the soul's involvement with the sensible realm by using Platonic and Aristotelic psychology. Even Evagrius' concept of apatheia, the chapter argues, seems to be closer to the Neoplatonic understanding of freedom from passions than that of the Stoics. In the final chapter of the volume, Tomas Ekenberg discusses whether Augustine's notion of the happy life in fact agrees with that of the Epicureans. Augustine is one of the Christian intellectuals that frequently is cast as a "Christian Platonist" in scholarly literature, but despite all his appropriations and explicit endorsement of Platonism, he sometimes departs from their philosophy in ways that can be unexpected. Defending his claim, Ekenberg contends that the many positive valuations of pleasure in Augustine ought to be accounted for, and argues that his position is more similar to the Epicureans' than any other philosophical school in Antiquity.

\section{Irreconcilable differences}

How far did Christian receptions of Platonism extend? Let us first consider the expression "Christian Platonism," which frequently occurs in scholarship, and which suggests something like a synthesis forged between Christianity and Platonism in Late Antiquity. As a historical claim, it seems to be supported by the widespread appropriation of Platonic material that one finds in Christian writings. We submit, however, that any such claim about a historical fusion or synthesis between the two movements is misguiding. Despite the extent of these appropriations, we need as historians of philosophy to acknowledge that Christian integration of Platonism had its limitations. Unconditional approval of Platonism is after all not possible to find in any Christian writer from this period. On the contrary, evidence indicates that even the most sympathetic Christians always had some reservations about Platonism - including Christian writers who were inclined to integrate larger portions of Platonic philosophy in their thought. Augustine for example, despite all his enthusiasm for the discovery of the Platonic treatises that prompted his conversion, always dissociated himself from those of the Neoplatonist claims that went contrary to the faith, even in the fledgling years of his career, when he had but an elementary understanding of Christian doctrines. ${ }^{11}$ 
In this regard, Dörrie has claimed that any historical analysis of Christian receptions of Platonism should recognize the differences and boundaries which Christians perceived between their own views and those of the Platonists. ${ }^{12}$ According to Dörrie's argument, the essential doctrines of the Platonic movement were all rejected by Christians. To take one of Dörrie's examples, Nicene Christians could impossibly accept any doctrine which stratified the divinity - such a doctrine was however essential to Neoplatonic metaphysics. Christian reception was therefore never substantial; it was limited to fragments and pieces that were incorporated into Christian thought. The observation of such irreconcilable differences between Platonism and Christianity led Dörrie to the conclusion that not only was there never such a thing as Christian Platonism in this period - according to him, there was only a Christian "anti-Platonism." While the latter may be a somewhat exaggerated claim, we think Dörrie is correct to the extent that despite widespread sympathy, no Christian writer from this period gave their full endorsement to the Platonists or completely adopted Platonic philosophy. From the Christian view, there was always a chasm separating the faith from paganism, and wherever there was endorsement, there was only conditional endorsement - which made any hypothetical "Christian Platonism" impossible. Christian intellectuals were understandably wary of endorsing Platonism - and, in cases of endorsement only did so by adding cautious disclaimers. Notwithstanding the truths it was held to communicate, Platonism was always held at a distance from the truth itself. From this perspective, there always remained a basic flaw about the Platonic system in the eyes of Christians since, despite their achievements within rational inquiries, the Platonists had been ignorant of or neglected Revelation.

The history of philosophy in Late Antiquity cannot exclusively be described in terms of continuities. ${ }^{13}$ Cracks and ruptures in the transitions of the GrecoRoman world in this period are as much part of this history as the continuities, if we are to give a correct representation of the period. The editors of this volume do not believe that the many observations of appropriation of Platonic material justify any claim that early Christianity forged a synthesis with Platonism. Further studies into Christian receptions of Platonism in Late Antiquity will bring more knowledge about how Christian writers mediated that material by way of selections and interpretations. These cracks have their rightful place in the history as well - late ancient history is not to be regarded as an intellectual relay in which Christians transmitted what the genius of the Greeks had invented. Such cracks and ruptures cannot only be studied in the polemics of Christian writers against paganism - they can also be observed and studied in any reception of pagan material by inquiring into how that material was transformed when transported into Christian contexts. What we study when we study the receptions of Platonism is necessarily excerpts that were taken from one context and placed into another. In Christian contexts, the philosophical material was interpreted from new perspectives, with new meaning being added.

$$
* * *
$$

In selecting the chapters contained in this volume on the relationship between Platonism and Christian thought, we have not wanted to outline any particular 


\section{Lars Fredrik Janby et al.}

historical development, and any sketch of the history of Christian philosophy in this period has been beyond the scope of this volume. ${ }^{14}$ With the aim to explore the relationship between Platonism and Christianity in Late Antiquity, we have been interested in Christian thought broadly defined, and not necessarily Christian philosophical receptions. This is not to say that we do not think that there was such a thing as Christian philosophy in this period. In the course of the last few decades, the study of Christian philosophy in Late Antiquity has increased in scholarship, obliterating some of the old bifurcation between philosophy and religion/theology, and important contributions have provided new knowledge about how we meaningfully can speak about early Christian philosophy, such as Georgios Karamanolis and his The Philosophy of Early Christianity. In making this provision, we do still acknowledge that a number of contributions in this volume examine receptions which deal with what must be considered philosophical problems in their own right, in discussing the receptions of Platonic material within rational inquiries into the faith.

\section{Notes}

1 Dörrie 1976.

2 Augustine, Civ. Dei 8.5.

3 Cf. Gnilka 1984.

4 Cf. Bland Simmons 2015.

5 Augustine, Conf. 7.9.13.

6 Clement, Str. 5.103.

7 Justin, $A p .1 .60 .1$.

8 Cf. De Vogel 1985.

9 Cf. Runia 1968.

10 For example, these findings call into question established knowledge on Augustine's intellectual conversion. Augustine's claim in Conf. that he acquired his notion of evil from the Platonists' monistic view of reality (generally believed to have been Plotinus) does not sit well with the dualistic views that Plotinus held, as shown by his doctrine on matter, which hardly could find any place within mainstream Christian doctrine on creation.

11 Cf. Augustine, Contra Academicos 3.20.43.

12 Dörrie 1976: 522.

13 Dörrie 1976: 521-522.

14 We agree with Stead 1994: x, who argues that any sketch of the development of Christian philosophy in this period is made difficult by the lack of convergence in philosophical knowledge and preferences among early Christian intellectuals.

\section{Bibliography}

\section{Primary sources}

Dombart, Bernhard and Alfons Kalb (eds.) (1955). Sancti Aurelii Augustini De civitate dei libri I-X. CCSL. Vol. 47. Turnhout: Brepols.

Green, William G. (ed.) (1970). Sancti Aurelii Augustini Contra academicos libri tres. CCSL. Vol. 29. Turnhout: Brepols.

Le Boulluec, Alain (ed.) (1981). Clément d'Alexandrie, Les Stromates. Vol. 1. Paris: Le Cerf. 
Munier, Charles (ed.) (2006). Justin, Apologie pour les Chrétiens. Paris: Le Cerf.

Verheijen, Luc (ed.) (1981). Sancti Aurelii Augustini Confessionum libri XIII. CCSL. Vol. 27. Turnhout: Brepols.

\section{Scholarly literature}

Bland Simmons, Michael (2015). Universal Salvation in Late Antiquity: Porphyry of Tyre and the Pagan-Christian Debate. Oxford: Oxford University Press.

De Vogel, Cornelia Johanna (1985). "Platonism and Christianity: A Mere Antagonism or a Profound Common Ground.” Vigiliae Christianae 39.1: 1-62.

Dörrie, Heinrich (1976). "Was ist Spätaniker Platonismus? Überlegungen zur Grenzziehung zwischen Platonismus und Christentum.” In Platonica Minora, 508-523. Munich: Wilhelm Fink Verlag.

Gnilka, Christian (1984). Khresis: Die Methode der Kirchenväter im Umgang mit der antiken Kultur; 1. Der Begriff des 'rechten Gebrauchs'. Basel/Stuttgart: Schwabe \& Co.

Karamanolis, George (2013). The Philosophy of Early Christianity. Durham: Acumen.

Runia, David T. (1968). Philo of Alexandria and the Timaeus of Plato. Leiden: Brill.

Stead, Christopher (1994). Philosophy in Christian Antiquity. Cambridge: Cambridge University Press. 
Logos, he read the Bible, or he was inspired by God. To account for his disagreement, they could argue that he failed to have complete access to truth, that he misunderstood what he read, or that he deliberately chose to lie in order to deceive the Athenians.

\section{Notes}

1 On this general topic, among many publications devoted to the influence of Platonism on patristic thought, see Wolfson 1956; Crouzel 1962; Madec 1974; 1996; Pépin 1999, 1972' ; Moreschini 2004; Karamanolis 2013 and 2014.

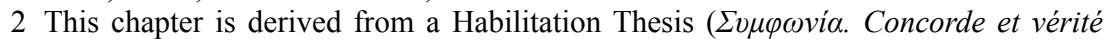
des textes dans la littérature grecque jusqu'à Origène, Paris, 2016) and two previous books: Morlet 2014 and 2016. Unless stated otherwise, the translations are the author's.

3 See Hélène Grelier Deneux's remarks in Pouderon et al. 2016: 1305.

4 Tatian, Oratio ad Graecos 2-3.

5 Theophilus, Aut. 2.4.

6 Theophilus, Aut. 3.7.

7 Tertullian, De anima 54.2.

8 The name often given to the author of the Refutation of all heresies $(1.19$; in 6.3, Plato is mentioned, with Pythagoras, as the supposed source of the gnostic Valentinus). The work (10.32.4), refers to a treatise previously written by its author "On the

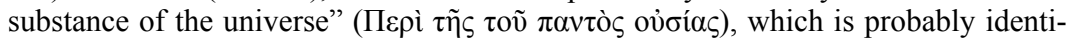

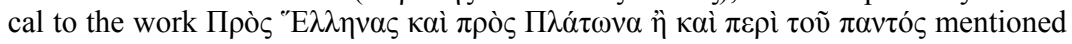
under the so-called "statue of Hippolytus" (see Prinzivalli 1990) and which Photius may describe (as a work of "Josephus") in his Bibliotheca, cod. 48 (Plato contradicts himself, and the views of Alcinoos concerning the soul, matter and resurrection, are wrong).

9 Justin, Dial. 2.3-6.

10 Justin, Dial. 2.6. Trans. ANF 1.

11 Constantine, Oratio ad sanctorum coetus 9.3 .

12 Eusebius, $P E$ 11.1.3-5.

13 Augustine, Civ. Dei 8.5.

14 Justin, trans. ANF 1.

15 Justin, Ap. 1.8.4.

16 Justin, Ap. 1.18.5.

17 Justin, Ap. 1.60.1.

18 "Related to the King of All are all things, and for his sake they are, and of all things fair $\mathrm{He}$ is the cause. And related to the Second are the second things and related to the Third the third." Trans. R. G. Bury.

19 Justin, $A p$. 1.13.3; 60.7.

20 Justin, Ap. 2.10.5-6.

21 Athenagoras, Leg. 6.1-4.

22 Athenagoras, Leg. 12.2.

23 Athenagoras, Leg. 16.4.

24 Athenagoras, Leg. 19.2.

25 Athenagoras, Leg. 23.5-7.

26 Athenagoras, Leg. 36.3.

27 Athenagoras, trans. ANF 2.

28 It is sometimes thought that Athenagoras was a real "philosopher," in the pagan sense. Bernard Pouderon believed that he was at the head of a Platonic school in Athens, before moving to Alexandria (Pouderon 1992: 17-22). This assumption is based 


\section{Sébastien Morlet}

primarily on Philip of Sidè (Historia Christiana, 1. 1-9 Hansen), which is obviously not reliable, and is, in itself, highly disputable, Athenagoras showing only a superficial knowledge of Platonism. In the manuscripts, Athenagoras is called "philosopher" and "Athenian." It is difficult to evaluate the reliability of such designations, and to understand if "philosopher" means that he practiced greek philosophy or just that he was a Christian theologian. Even understood in the pagan sense, it may have come to the mind of the copists because of the numerous philosophical quotations contained in the Legatio. Philip's "novel" about Athenagoras is probably an extrapolation based on the two designations of the Christian in the manuscripts - "philosopher" and "Athenian." It transmits no historical data.

29 Clement, Pr. 70.1; Str. 1.66.3.

30 Clement, Str. 5.92.1-4.

31 Clement, Str. 5.92.5-6.

32 Clement, Str. 5.103.1.

33 Clement, Str. 5.103.2-4.

34 Clement, Paed. 2.18.1

35 Clement, Paed. 2.22.1.

36 Clement, Str. 1.9.4.

37 Clement, Str. 5.93.2-3.

38 Clement, Str. 1.165.2.

39 Clement, Str. 2.100.4.

40 Translations of Clement are taken from ANF 2.

41 Clement, Str. 5.106.2.

42 Clement, Str. 5.108, 2-3.

43 Clement, Str. 6.42.3.

44 Clement, Str. 1.5.28; 6.67.1.

45 In my view, it is necessary to distinguish between Origen the Christian and Origen the Platonist, though a few scholars have sometimes been tempted to identify them. The chronology of the Christian's life does not fit with the few things we know about Origen the Platonist: at the time when Plotinus, the fellow-disciple of Origen the pagan, opened a school in Rome (246), the Christian was already a famous figure in the Church and died about eight years later (see Dorival 2005).

46 See Eusebius, Historia ecclesiastica 6.24.3.

47 See Geerard, $n^{\circ}$ 1483. Nautin gave a list of fragments available in 1977 (Nautin 1977: 295). More recently, see Moreschini 1987.

48 Jerome, Letter 70.4: "Origenes decem scripsit Stromateas, Christianorum et philosophorum sententias conparans, et omnia nostrae religionis dogmata de Platone et Aristotele, Numenio, Cornutoque confirmans." In another text, Jerome alludes to the use of the Stoics in the work (Dialogue against the Pelagians Prologue. 1).

49 See Nautin 1972.

50 See Jerome, Apologia contra Rufinum 1.18.

51 Saffrey 1975.

52 Morlet 2004.

53 Eusebius, $P E$ 12.31.

54 Morlet 2013.

55 Eusebius, $P E$ 11.5-6.

56 Eusebius, $P E$ 11.7-38.

57 Eusebius, $P E$ 12.1-13.11.

58 See Whittaker and Louis 1990 (dialectical part: 4-6; theoretical part: 7-26; ethical part: 27-34).

59 See Goulet-Cazé 1999 (physics: 67-77; ethics: 78-106; the last part of Diogenes's exposition is devoted to the divisions of reality: 106-109).

60 Eusebius, $P E$ 11.10.14.

61 Eusebius, $P E$ 11.10.15. 
62 Eusebius, $P E$ 11.13.

63 Eusebius, $P E$ 11.14.

64 Eusebius, $P E$ 11.26.

65 Eusebius, $P E$ 11.32.

66 Eusebius, $P E$ 11.33.

67 Eusebius, $P E$ 12.18.

68 Eusebius, $P E$ 12.35.

69 Eusebius, $P E$ 12.40-41.

70 Eusebius, $P E$ 13.1.

71 Eusebius, $P E$ 11.24.

72 Eusebius, $P E 12.8$.

73 Eusebius, $P E$ 12.20.

74 Eusebius, $P E$ 12.25.

75 Eusebius, $P E$ 11.4.

76 Eusebius, $P E$ 11.5.

77 Eusebius, $P E$ 11.14.

78 Eusebius, $P E$ 12.34.

79 Justin, Ap. 1.44.9.

80 Justin, Ap. 1.60.1-7.

81 Justin, Ap. 1.46.

82 Justin, Ap. 2.7.1-2; 10.8; 13.3-5.

83 Athenagoras, Leg. 7.2.

84 Clement, Str. 1.94.2.

85 Clement, $P r$. 68.3-4.

86 Clement, Paed. 1.67.1-2.

87 Clement, Paed. 2.10.89.

88 Clement, Paed. 2.100.3-4.

89 Clement, Pr. 70.1; Str. 1.66.3.

90 Clement, Str. 2.133.2.

91 Clement, Paed. 2.10.89.

92 Clement, Str. 2.18.2. Compare to Augustine, Civ. Dei 8.11: "Plato was not ignorant of those writings."

93 Clement, Str. 5.102.3.

94 See Origen, C. Cels. 4.39, the Refutation of all the heresies sometimes ascribed to Hippolytus, 6.21.1-3, Ps.-Justin, Cohortatio ad Graecos 20.1; Augustine, Civ. Dei 8.11; Theodoretus of Cyrrhus, Therapeutics of Hellenic maladies 2.26.

95 See Diogenes Laertius, Vitae philosophorum 3.6.

96 In Civ. Dei 8.11, Augustine assumes that Plato happened to know the Scriptures through an interpreter, since the Greek translation had not yet occurred. Origen (C. Cels. 4.39) already alluded to the same kind of explanation ("it is not very clear, indeed, whether Plato fell in with these stories by chance, or whether, as some think, meeting during his visit to Egypt with certain individuals who philosophised on the Jewish mysteries").

97 Clement, Str. 5.29.3-6.

98 Origen, Princ. 1.3.6; C. Cels. 4.85.

99 See Origen, Princ. 2.1.2; 2.9.6.

100 Origen, C. Cels. 7.30.

101 Origen, C. Cels. 6.19. Translations of Contra Celsum are taken from ANF 4.

102 Origen, C. Cels. 4.39.

103 Origen, C. Cels. 3.47; 4.30; Commentary to Romans 1.19.

104 Origen, Homilies on Numbers 18.3.

105 Eusebius, $P E$ 11. Pr.1. Trans. E.H. Gifford.

106 Eusebius, $P E$ 11.13.5.

107 Justin, $A p$. 2.10.7. 
108 Athenagoras, Leg. 7.2.

109 Clement, $\operatorname{Pr}$. 74.7. See also Str. 6.7.55.4, which contains also the second explanation (they mistook their source: see below).

110 Origen, C. Cels. 7.51.

111 Eusebius, $P E$ 13.14.2.

112 Justin, $A p .1 .60 .1-7$.

113 Clement, Str. 6.7.55.4.

114 Clement, Str. 5.89.4.

115 Clement, Str. 5.90.2.

116 Clement, Str. 5.90.3.

117 Origen, C. Cels. 7.30.

118 See Origen, C. Cels. $6.7 ; 15 ; 19 ; 32$.

119 See Morlet, forthcoming.

120 Eusebius, $P E$ 13.16.18.

121 See Origen, C. Cels. 4.39; Eusebius, PE 13.14.

\section{Bibliography}

\section{Primary sources}

\section{a. Editions}

Bardy, Gustave and Gustave Combès (eds. and trans.) (1959). Augustin, La cité de Dieu. Bibliothèque augustinienne 33-37. Paris: Desclée de Brouwer.

Camelot, Pierre-Thomas, Marcel Caster, Alain Le Boulluec, Patrick Descourtieux, Claude Mondésert, Annewies Van den Hoek and Pierre Voulet (eds. and trans.) (1951-2009). Clément d'Alexandrie, Les Stromates. SC 30-38-278-279-428-446-463. Paris: Le Cerf.

Canivet, Pierre (ed. and trans.) (1958). Théodoret de Cyr, Thérapeutique des maladies helléniques. SC 57 (1-2). Paris: Le Cerf.

Crouzel, Henri and Manlio Simonetti (eds. and trans.) (1978-1984). Origène, De principiis. SC 252-253-268-269-312. Paris: Le Cerf.

Des Places, Édouard, Geneviève Favrelle, Guy Schrœder, Jean Sirinelli and Odile Zink (eds. and trans.) (1974-1991). Eusèbe de Césarée, Préparation évangélique. SC 206215-228-262-266-292-307-338-369. Paris: Le Cerf.

Doutreleau, Louis (ed. and trans.) (1996-2001). Origène, Homélies sur les Nombres. SC 415-442-461. Paris: Le Cerf.

Gifford, Edwin Hamilton (ed. and trans.) (1903). Eusebii Pamphili Evangelicae Praeparationis libri $X V$. Oxford: Typographeus Academicus.

Hammond Bammel, Caroline P. (ed.) (2009-2012). Origène, Commentaire sur l'Épitre aux Romains, trans. Luc Brésard and Michel Fédou. SC 532-539-543-555. Paris: Le Cerf.

Harl, Marguerite and Henri-Irénée Marrou (eds. and trans.) (1960-1970). Clément d'Alexandrie, Le pédagogue. SC 70-108-158. Paris: Le Cerf.

Heikel, Ivar August (ed.) (1902). "Constantins Rede an die heilige Versammlung." In Eusebius Werke, Vol. I, GCS. Vol. 7. Leipzig: J.C. Hinrichs.

Labourt, Jérôme (ed. and trans.) (1949-1963). Saint Jérôme, Lettres. Paris: Les Belles Lettres.

Lardet, Pierre (ed. and trans.) (1983). Jérôme, Apologie contre Rufin. SC 303. Paris: Le Cerf. 
Marcovich, Miroslav (ed.) (1986). Hippolytus, Refutatio omnium haeresium. Berlin/New York: De Gruyter.

(1995a). Tatiani oratio ad Graecos. Berlin/New York: De Gruyter.

(1995b). Theophili Antiocheni ad Autolycum. Berlin/New York: De Gruyter.

(1997). Iustini Martyri dialogus cum Tryphone. Berlin/New York: De Gruyter.

Mondésert, Claude (ed. and trans.) (1941). Clément d'Alexandrie, Le Protreptique. SC 2. Paris: Le Cerf.

Munier, Charles (ed. and trans.) (2006). Justin, Apologie pour les chrétiens. SC 507. Paris: Le Cerf.

Pouderon, Bernard (ed. and trans.) (1992). Athénagore, Supplique pour les chrétiens et Sur la résurrection des morts. SC 379. Paris: Le Cerf.

Waszink, Jan Hendrik (ed.) (1954). Tertulliani opera, pars II. CCSL. Vol. 2. Turnhout: Brepols.

Whittaker, John and Pierre Louis (eds. and trans.) (1990). Alcinoos: Enseignement des doctrines de Platon. Paris: Les Belles Lettres.

\section{b. Translations}

Bardy, Gustave (trans.) (1952-1960). Eusèbe de Césarée, Histoire ecclésiastique. SC 31-41-55-73bis. Paris: Le Cerf.

Borret, Marcel (trans.) (1967-1976). Origène, Contre Celse. SC 132-136-147-150-227. Paris: Le Cerf.

Bury, Robert Gregg (trans.) (1929). Plato, Timaeus, Critias, Cleitophon, Menexenus, Epistles. LCL. Cambridge, MA: Harvard University Press.

Goulet-Cazé, Marie-Odile (trans.) (1999). Diogène Laërce, Vies et doctrines des philosophes illustres. Paris: Livre de poche.

Pouderon, Bernard (trans.) (2009). Justin, Ouvrages apologétiques. SC 528. Paris: Le Cerf.

Roberts, Alexander and James Donaldson (trans.) (1967). Fathers of the Second Century: Hermas, Tatian, Athenagoras, Theophilus and Clement of Alexandria. Ante-Nicene and Nicene Fathers. Vol. 2. Grand Rapids: Eerdmans.

Roberts, Alexander, James Donaldson and A. Cleveland Coxe (trans.) (1969). The Apostolic Fathers. Ante-Nicene and Nicene Fathers. Vol. 1. Grand Rapids: Eerdmans.

Schaff, Philip (trans.) (1991). St. Augustine's City of God and Christian Doctrine. A Select Library of the Nicene and Post-Nicene Fathers of the Christian Church. Grand Rapids: Eerdmans.

\section{Scholarly literature}

Crouzel, Henri (1962). Origène et la philosophie. Paris: Aubier.

Dorival, Gilles (2005). “Origène d'Alexandrie.” In Dictionnaire des philosophes antiques, ed. Richard Goulet. Vol. 4, 807-842. Paris: CNRS Éditions.

Geerard, Maurice (1974). Clavis Patrum Graecorum. Vol. 1. Turnhout: Brepols.

Goulet-Cazé, Marie-Odile (ed.) (1999). Diogène Laërce: Vies et doctrines des philosophes illustres. Paris: Livre de poche.

Karamanolis, George E. (2013). The Philosophy of Early Christianity. Durham: Acumen.

- (2014). "The Platonism of Eusebius of Caesarea." In Plato in the Third Sophistic, ed. Ryan C. Fowler, 171-191. Berlin/New York: De Gruyter.

Madec, Goulven (1974). Saint Ambroise et la philosophie. Paris: Études augustiniennes. 


\section{Sébastien Morlet}

(1996). Saint Augustin et la philosophie. Paris: Études augustiniennes.

Moreschini, Claudio (1987). "Note ai perduti Stromata di Origene.” In Origeniana quarta, ed. Lothar Lies, 36-43. Innsbruck/Vienna: Tyrolia Verlag. (2004). Storia della filosofia patristica. Brescia: Morcelliana.

Morlet, Sébastien (2004). "Eusèbe de Césarée a-t-il utilisé les Stromates d'Origène dans la Préparation évangélique?” Revue de philologie 78: 127-140.

- (2013). "La Préparation évangélique d'Eusèbe et les Stromates perdus d'Origène: nouvelles considérations." Revue de philologie 87: 107-123.

(2014). Christianisme et philosophie: Les premières confrontations. Paris: Livre de poche.

- (2016). Les chrétiens et la culture: Conversion d'un concept. Paris: Les Belles Lettres.

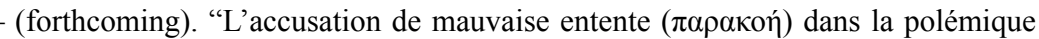
entre païens et chrétiens à la fin de l'Antiquité." In Dealing with Disagreement: The Construction of Traditions in Later Ancient Philosophy, ed. Albert Joosse and Angela Ulacco.

Nautin, Pierre (1972). "Une citation méconnue des Stromates d'Origène (Jérôme, C. Ioh. Hieros., 25).” In Epektasis, Mélanges Daniélou, ed. Jacques Fontaine and Charles Kannengiesser, 373-374. Paris: Beauchesne.

(1977). Origène. Paris: Beauchesne.

Pépin, Jean $\left(1999,1972^{1}\right)$. “La philosophie patristique.” In Histoire de la philosophie, ed. François Châtelet. Vol. 2, 61-105. Paris: Livre de poche.

Pouderon, Bernard, Jean-Marie Salamito and Vincent Zarini (eds.) (2016). Premiers écrits chrétiens. Paris: Gallimard.

Prinzivalli, Emanuela (1990). "Hippolyte (Statue d')." In Dictionnaire encyclopédique du christianisme ancien, ed. Angelo di Berardino. Vol. 1, 1164-1166. Paris: Le Cerf.

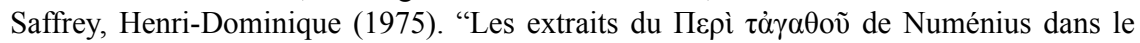
livre XI de la Préparation Evangélique." Studia patristica 13: 46-51.

Wolfson, Harry Austryn (1956). The Philosophy of the Church Fathers. Cambridge, MA: Harvard University Press. 


\section{Notes}

1 A controversy sparked by Alfaric 1918: 380-381, whose view that Augustine converted to Platonism before turning to Christianity is widely rejected today. More recently, Dobell 2009 has argued that Augustine's conversion from Porphyrian Neoplatonism to Christianity continued into the mid-390s.

2 The notorious reference to the "books of the Platonists" occurs at Conf. 7.9.13. Among Porphyry's champions are Theiler 1953; Beatrice 1989. O'Connell 1963 and Rist 1996 are in the Plotinian camp. See O'Donnell 1992 vol. 2: 412-443.

3 Crouse 1999 gives a survey of this and other problematic aspects of Augustine's Platonism, along with the most important literary references.

4 See Hoenig 2018: 227-228, 272-273. Rémy 1979: 545-596 uses Augustine's quotations of Tim. 29c3 in the Cons. ev. and Trin. as a springboard for a broader discussion of his soteriology and his views on the relationship between the temporal and eternal realms.

5 Justin, Ap. 20.4, 1-2.

6 See Niehoff 2007.

7 I follow the dating of Hombert 2000: 66-80, who places the beginnings of Trin. 1 around 400-403, shortly before Augustine composed the Cons. ev., dated to 403-404 (81-87). According to Hombert Augustine interrupted working on the Trin. and did not compose Book Four until 413-414, contra Camelot 1956, who suggests that Book Four was composed around the same time as the Cons. ev.

8 Trans. according to Lamb 1925 with modifications.

9 Augustine drops Cicero's connective enim at Cons. ev. 1.35 .53 and in the first of the two quotations at Trin. 4.18.24.

10 Augustine at Civ. Dei 13.16.1 also quotes Cicero's translation of Tim. 41a-b, the demiurge's speech to the subordinate divinities. The same passage features again at Civ. Dei 22.26 and other writings. Hagendahl 1967: 131-138 lists all of Augustine's quotations from Cicero's translation.

11 Cicero, Tim. 3.8.1-2, ed. Ax and Plasberg 2011.

12 I have argued previously, at Hoenig 2018: 98-101, that Cicero's surprising choice of aeternitas, "eternity," for ov่бía, "being," may be explained by the fact that he associated the eternal paradigm ( $\tau$ ò $\alpha \dot{i} \delta$ เov $\pi \alpha \rho \alpha \dot{\delta} \varepsilon 1 \gamma \mu \alpha$ ) after which the created world is modelled not with the realm of being, a generic ontological class, but with the Form of Eternity. In other words, Cicero makes our universe a copy, or an image, of the Form of Eternity, even though eternity is only one of the qualities possessed by a generic Platonic form. Cicero's chosen rendering aeternitas evidently had an impact on Augustine's understanding of the Timaeus. Ovंoía, intelligible being, is associated by him with the eternal life obtained after the human body's resurrection.

13 Augustine, Retr. 2.16.

14 Largely in line with J.J. O'Meara 1959, and contra Merkel 1996-2010: 1230 (and see ibid. 1971: 23-31), who suggests that the work is primarily targeting the Manicheans, a verdict that appears unnecessarily restrictive.

15 For a study of Origen's impact on Augustine, see e.g. Crouse 1992.

16 Epiphanius, Adversus haereses $51.8=$ fr. 55T Becker 2016. See also Merkel 1971: 13-18. Merkel at 1986-2010: 1230 doubts that Augustine knew Porphyry's Contra Christianos. Even if this is the case, the arguments contained in the work could likely have made their way to Augustine by the early fifth century.

17 E.g. Cons. ev. 11.17; 9.14.

18 Augustine, C. Faustum 32.2; 33.3. Hombert 2000 dates this work to 400-402.

19 Tertullian, Apologeticum 21.17; Lactantius, Divinae institutiones 4.13.17.

20 See, for instance, Jerome, Tractatus LIX In psalmos 81, Z. 206-239 (= 70F Becker 2016), according to whom Porphyry (at Z. 228) suspects the evangelists of magic and thaumaturgy undertaken for financial gains. The Middle Platonist Apuleius and the 
Neopythagorean Apollonius of Tyana are listed as further examples of thaumaturgy ( $Z$. 228-229).

21 The most important study on the various views concerning Jesus held by Augustine's non-Christian contemporaries is Madec 1992; see esp. 48-67 for the present context. Dodaro 2004: 95 discusses Augustine's treatment of such views in his Civ. Dei.

22 On the details of this oracle see e.g. Courcelle 1954. Becker 2016: 370 notes that Hecate's oracle confirms Jesus' piety (345F, 9.25.25-30, ed. Smith 1993), but that, according to Porphyry's reading, it is Jesus' immortal pious soul only that Christians erroneously worship.

23 Elsewhere, he holds the predictions of the Hebrew prophets up as a defence against the charge of magic or thaumaturgy against Jesus. At C. Faust. 12.45, he argues that "the testimony of the prophets (prophetae) who lived so long before could not be ascribed to magical arts."

24 Lucan, De bello civili 2.592-593.

25 See n. 12.

26 The idea of a required middle term is inspired by Tim. 31b4-32c4 where Timaeus makes reference to geometrical proportion in the context of the four material elements that make up the cosmos. Between any two extremes, the most effective bond for achieving true unity is that which is able to assimilate itself to the two extremes it unites (31c2-3), with the help of proportion ( $\dot{\alpha} v \alpha \lambda \sigma \gamma i \alpha)$ : "Whenever the middle term of three numbers (. . .) between any two of them is such that what the first term is to it, it is to the last, and, conversely, what the last term is to the middle term, it is to the first, then, since the middle term turns out to be both first and last, and the last and the first likewise both turn out to be middle terms, they will all of necessity turn out to have the same relationship to each other, and, given this, will be unified" (Tim. 31c4-32a7, trans. Zeyl). See my further analysis of this passage, as appropriated by Augustine, at Hoenig 2018: 260-262.

27 McGrath 1986 vol. 1: 39 dates this development to 396-397, as visible in the two volumes addressed to Simplicianus and Augustine's comments at De praedestinatione sanctorum 4.8 .

28 See Dodaro 2004: 76; Merkel 1971: 224-227.

29 Courcelle 1954 suggests that the arguments Augustine counters in the Cons. ev. reflect a mix of criticisms, often similar in nature, from various corners. Criticisms that originated with Celsus or Porphyry could likely have been appropriated by followers of other anti-Christian convictions.

30 Cf. Vulg. Heb 7:12, 7:24.

31 Hombert 2000: 45-80.

32 See Drecoll 1996-2002: 631. Ayres 2010: 166 notes that "the De trinitate may have been rendered increasingly anti-Pelagian during later redaction," a possible reason why the work as we have it frequently stresses the necessity of grace for our contemplation of god. An attempt to link Augustine's stress on the necessity of grace to his altercations with the Pelagians was made by Plagnieux 1954. In the specific context of Trin. 4.1.24, Augustine appears to me to be addressing primarily Homoian and Platonic perspectives.

33 See Barnes 1999 for a study of Augustine's anti-Homoian stance particularly in Book One.

34 Trans. according to Hill 1991 with modifications.

35 See the discussion by Barnes 1999; Ayres 2010: 142-170.

36 See Hill 1991 in his introductory essay at 147-151 who, however, acknowledges the overall thematic cohesion between Christ's mediatory role and the divine missions. Bochet 2007 defends the structure of Book Four, especially with regard to 4.2.11 and 4.2.12. See further Ayres 1998; Arnold 1991.

37 See Ayres 2010: 166-170; Rémy 1979: 573-574.

38 See for instance Plato, Phileb. 15a-b, 16c-e, 17c-e; Plotinus, Enn. 6.6.1; Porphyry, Sent. 11.37. See also the chapter of Janby in this volume for a fuller account of Augustine's philosophy of number. 
39 Solignac 1958 examines the Pythagorean echoes in Augustine, which, he argues, reached him via Varro or Nicomachus of Gerasa (via Apuleius' Latin translation).

40 Noted by Hombert 2000: 73. I would add that the contrast at 4.3 .13 between the devil who "grew high and mighty" and Christ who came "humble and lowly" echoes Augustine's polemic against Apuleius' demonology in Book Eight of his Civ. Dei where he "inverts" the demonic-human hierarchy by pointing to the inferiority of the light and airy demons, weighed down by their depravity, over against the moral loftiness of mortals who possess an inferior elemental make-up. Cf. Hoenig 2018: 272-277.

41 At Doctr. Chr. 2.28.43 Augustine suggests Plato may have obtained his wisdom from Jeremiah on his travels to Egypt, a view he later came to reject. See also Hoenig 2018: 225.

42 Concerning the theme of belief and contemplation of the truth, Augustine there had reproached those who are "so top-heavy with the load of their mortality that what they do not know they wish to give the impression of knowing, and what they wish to know they cannot, and so they block their own road to genuine understanding by asserting too categorically their own presumptuous opinions (...)."

\section{Bibliography}

\section{Primary sources}

\section{a. Editions}

Ax, Wilhelm and Otto Plasberg (eds.) (2011). M. Tulli Ciceronis De Divinatione; De Fato; Timaeus. Revised edition. Stuttgart: Teubner.

Becker, Matthias (ed.) (2016). Porphyrios, 'Contra Christianos': Neue Sammlung der Fragmente, Testimonien und Dubia mit Einleitung, Übersetzung und Anmerkungen. Berlin/Boston: De Gruyter.

Brandt, Samuel (ed.) (1890). Lactantius, Divinae institutiones, Epitome divinarum institutionum. CSEL 19. Prague/Vienna: F. Tempsky.

Burnet, John (ed.) (1901a). Platonis Opera, Vol. 2: Parmenides, Philebus, Symposium, Phaedrus, Alcibiades I and II, Hipparchus, Amatores. Oxford: Clarendon Press. (1901b). Platonis Opera, Vol. 4: Clitopho, Respublica, Timaeus, Critias. Oxford: Clarendon Press.

Green, William (ed.) (1963). Augustinus, De Doctrina Christiana. CSEL 80. Vienna: Hölder-Pichler-Tempsky.

Henry, Paul and Hans-Rudolf Schwyzer (eds.) (1973). Plotini Opera. 3 vols. Leiden: Brill. Hoppe, Heinrich (ed.) (1939). Tertullianus, Apologeticum. CSEL 69. Vienna: HölderPichler-Tempsky.

Knöll, Pius (ed.) (1902). Retractationes. CSEL 36. Leipzig: G. Freytag.

Lamberz, Erich (ed.) (1975). Porphyrii Sententiae ad Intelligibilia Ducentes. Leipzig: Teubner.

O'Donnell, James J. (trans.) (1992). Augustine, Confessions: Text and Commentary. 3 vols. Oxford: Oxford University Press.

Smith, Andrew (ed.) (1993). Porphyrii Philosophi Fragmenta. Stuttgart: Teubner.

Weihrich, Franz (ed.) (1904). De Consensu Evangelistarum Libri Quattuor. CSEL 43. Vienna: F. Tempsky.

Zycha, Joseph (ed.) (1891). Contra Faustum Manichaeum. CSEL 25/1. Prague: F. Tempsky.

\section{b. Translations}

Hill, Edmund (trans.) (1991). The Trinity: The Works of Saint Augustin: A Translation for the 21st Century. Brooklyn, NY: New City Press. 
Lamb, Walter R.M. (trans.) (1925). Plato in Twelve Volumes. Vol. 9. Harvard: Harvard University Press.

Zeyl, Donald J. (trans.) (2000). Plato, Timaeus. Indianapolis: Hackett.

\section{Scholarly literature}

Alfaric, Prosper (1918). L'Evolution Intellectuelle de Saint Augustin. Vol. 1. Paris: E. Nourry.

Arnold, Johannes (1991). "Begriff und Heilsökonomische Bedeutung der Göttlichen Sendungen in Augustinus' De Trinitate." Recherches Augustiniennes 25: 3-69.

Ayres, Lewis (1998). “The Christological Context of Augustine's De Trinitate XIII: Towards Relocating Books VIII-XV.” Augustinian Studies 29.1: 111-139.

(2010). Augustine and the Trinity. Cambridge: Cambridge University Press.

Barnes, Michel R. (1999). "Exegesis and Polemic in Augustine's De Trinitate I." Augustinian Studies 30: 43-59.

Beatrice, Pier F. (1989). "Quosdam Platonicorum Libros: The Platonic Readings of Augustine in Milan." Vigiliae Christianae 43: 248-281.

Bochet, Isabelle (2007). "The Hymn to the One in Augustine's De Trinitate IV." Augustinian Studies 38.1: 41-60.

Camelot, Pierre-Thomas (1956). "A l'Éternel par le Temporel (De Trinitate IV, XVIII, 24)." Revue des Études Augustiniennes et Patristiques 2: 163-172.

Courcelle, Pierre (1954). "Saint Augustin 'Photinien' à Milan (Conf. 7.19.25)." Ricerche di Storia Religiosa 1: 63-71.

Crouse, Robert (1992). "The Influence of Origen in the Philosophical Tradition of the Latin West: Augustine and Eriugena.” In Origeniana Quinta, ed. Robert J. Daly, 565-569. Leuven: Peeters.

- (1999). "Paucis Mutatis Verbis.” In Augustine and His Critics, ed. Robert Dodaro and George Lawless, 37-50. London/New York: Routledge.

Dobell, Brian (2009). Augustine's Intellectual Conversion: The Journey from Platonism to Christianity. Cambridge: Cambridge University Press.

Dodaro, Robert (2004). Christ and the Just Society in the Thought of Augustine. Cambridge: Cambridge University Press.

Hagendahl, Harald (1967). Augustine and the Latin Classics. 2 vols. Gothenburg: Almquist and Wiksell.

Hoenig, Christina (2018). Plato's Timaeus and the Latin Tradition. Cambridge: Cambridge University Press.

Hombert, Pierre-Marie (2000). Nouvelles Recherches de Chronologie Augustinienne. Paris: Études Augustiniennes.

Madec, Goulven (1989). "Le Néoplatonisme dans la Conversion d'Augustin: Etat d'une Question Centenaire (Depuis Harnack et Boissier, 1888).” In Internationales Symposion über den Stand der Augustinus-Forschung, ed. Cornelius Mayer and Karl Heinz Chelius, 9-25. Würzburg: Augustinus-Verlag.

(1992). "Le Christ des Paiëns d'après le De consensu evangelistarum de Saint Augustin." Recherches Augustiniennes 26: 3-67.

McGrath, Alister (1986). Iustitia Dei: The History of the Christian Doctrine of Justification, Vol. 1: From the Beginning to 1500. Cambridge: Cambridge University Press.

Merkel, Helmut (1971). Die Widersprüche zwischen den Evangelien: Ihre Polemische und Apologetische Behandlung in der Alten Kirche bis zu Augustin. Tübingen: Mohr Siebeck.

Niehoff, Maren R. (2007). "Did the Timaeus Create a Textual Community?" Greek, Roman, and Byzantine Studies 47: 164-170. 


\section{Christina Hoenig}

O'Connell, Robert J. (1963). "Ennead VI.4 and 5 in the Works of St. Augustine." Revue des Études Augustiniennes 9: 1-39.

O’Meara, John J. (1959). Porphyry's Philosophy from Oracles in Augustine. Paris: Études Augustiniennes.

Plagnieux, Jean (1954). "Influence de la Lutte Antipélagienne sur le De Trinitate ou: Christocentrisme de Saint Augustin.” In Augustinus Magister. Vol. 2, 817-826. Paris: Études Augustiniennes.

Rémy, Gérard (1979). "Le Christ Médiateur dans l'Oeuvre de Saint Augustin.” Doctoral Thesis, Paris/Lille.

Rist, John (1996). Man, Soul, and Body: Essays in Ancient Thought from Plato to Dionysius. Aldershot: Variorum.

Solignac, Aimé (1958). "Doxographies et Manuels dans la Formation Philosophique de Saint Augustin.” Recherches Augustiniennes 1: 129-137.

Theiler, Willy (1953). Porphyrios und Augustin. Schriften der Königsberger Gelehrten Gesellschaft, Geisteswiss. Klasse 10/1. Halle: Niemeyer. 
to denounce pagan philosophy and religion by emphasising a term that has negative connotations for a Christian.

\section{Conclusive Remarks}

Lastly, I wish to revisit the question whether the Philosophia ex oraculis as a whole can be understood as an anti-Christian text. The Platonist introduces his text as a way of salvation. In 303F. Smith, which belongs to the beginning of the text, he says: "Sure, then, and steadfast is he who draws his hopes of salvation from this as from the only sure source." ${ }^{" 38}$ While this claim could appear to be an alternative to Christian salvation, it does not seem that the addressees in this context are Christians. Rather, Porphyry appeals to a group of "initiated." Fragment 304F. Smith of the Philosophia ex oraculis says:

And do thou endeavor to avoid publishing these above all things, and casting them even before the profane for the sake of reputation, or gain, or any unholy flattery. For so there would be danger not only to thee for transgressing these injunctions, but also to me for lightly trusting thee who couldst not keep the benefits secret to thyself. We must give them then to those who have arranged their plan of life with a view to the salvation of the soul. ${ }^{39}$

Thus, there is no evidence to support the claim that Christianity was a main topic of the Philosophia ex oraculis. ${ }^{40}$ Whereas Contra Christianos evidently was written against the Christians, the direction of impact of the Philosophia ex oraculis cannot be answered with the same clearness. Themes that Porphyry is talking about in this text, like the daemons, are understood or made to appear antiChristian by Eusebius. Porphyry's addressees are not the Christians, but rather people who are interested in philosophy. The text stresses and uses elements that are essential for the pagan self-conception, as for example, the fact that Porphyry uses oracles for his argumentation. So, even if not intended as an anti-Christian text by Porphyry, Eusebius understands it as at least antithetical to Christianity and as such he attacked it as a threat, staging, and ridiculing the Neoplatonist as an enemy by representing his views on the daemons.

\section{Notes}

1 This chapter has been written in connection with the research at the project G01 "Platonism and Christianity in late antiquity - Porphyry's interpretation, defense and re-ordering of pagan cultic practice: A threat to the Christian order?" of the Collaborative Research Center 923 "Threatened Order - Societies under Stress" (University of Tübingen), which is sponsored by the DFG (German Research Foundation). I would like to thank David DeMarco (Tübingen) and Aaron Johnson (Cleveland, TN) for valuable comments, as well as for proofreading.

2 Goulet 2012: 1289-1314.

3 Johnson 2006: 11-12.

4 Johnson 2006. 
5 Cf. Johnson 2013: 79.

6 Cf. Johnson 2013: 81.

7 Magny 2014 also pointed to the significance of being aware of the citation contexts, when dealing with Porphyry.

8 Riedweg 2005: 155-158; Tanaseanu-Döbler 2009: 120 and 2017: 137-140 provide a detailed survey of the scholarly debate.

9 Bidez 1913: 15-28.

10 O'Meara 1959 and 1969.

11 Beatrice, 1988, 1989, 1992, 1993. Cf. Becker 2016: 15, n. 84; 16, n. 92.

12 Riedweg 2005.

13 Becker 2016: 32-85.

14 Busine 2004; cf. also Busine 2005: 292-295.

15 Eusebius, PE IV.5.4; Gifford 1903: 155.

16 Becker 2016: 368, n. 1.

17 Porphyry, Philos. ex orac. 326F., 1-3 Smith = Eus. PE IV.22: "And who the power presiding over them happens to be, shall be made clear by the same author again, who says that the rulers of the wicked daemons are Sarapis and Hecate. ( $\tau$ í $\tau_{\varepsilon} \dot{\eta} \pi \rho \circ \varepsilon \sigma \tau \tilde{\omega} \sigma \alpha$

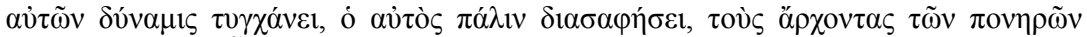

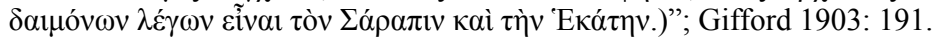

18 Since I have analysed and discussed fragment 307F. Smith at length in a paper (Hecht, forthcoming), I only cite part of the Greek text and only mention the major aspects for the argumentation here.

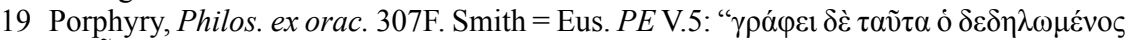

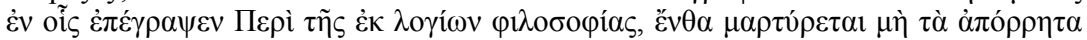

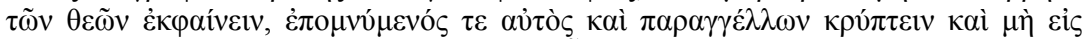

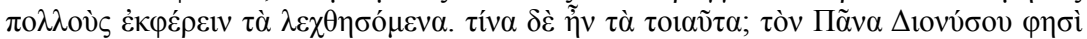

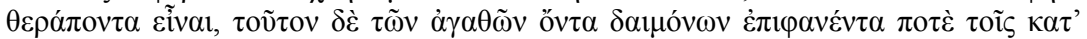

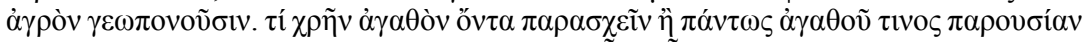

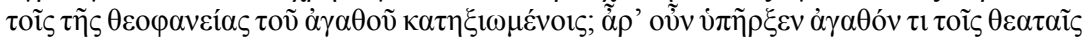

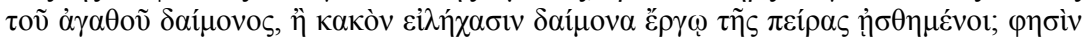

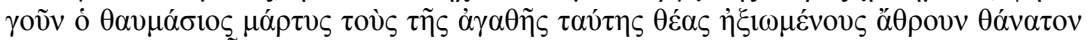

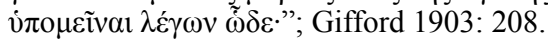

20 Porphyry, De abst. II.38-43; Ad Marc. 21. For Porphyry's daemonology: Wolff 1856: 214-299; Timotin 2012: 208-215; Johnson 2013: 83-101; cf. also Muscolino 2010: 103-123.

21 Porphyry, Philos. ex orac. 326F., 327F., 329F., 346F. Smith.

22 I got the idea from Aaron Johnson (Cleveland, TN), who pointed out that Eusebius could not have made outright lies about Porphyry because his audience would have recognised it.

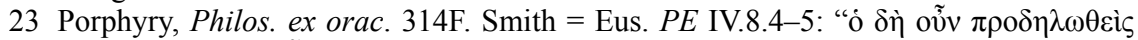

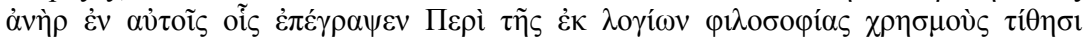

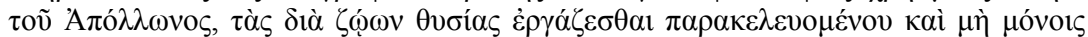

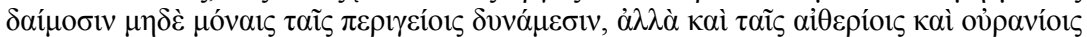

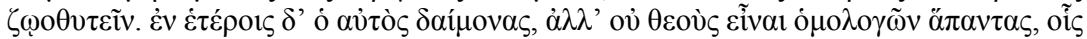

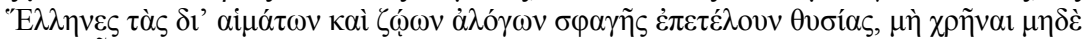

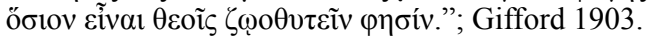

24 Johnson 2013: 83-101. Recently, Brisson 2018 has depicted Porphyry' theological system and the position of the "daemon" in it. He draws mainly on the De abstinentia, while omitting the fragments of the Philosophia ex oraculis.

25 Johnson 2013: 90.

26 Ibid.: 91.

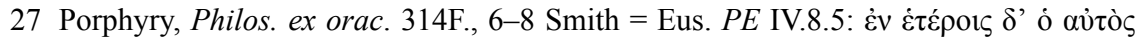

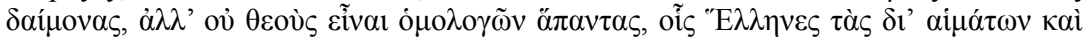

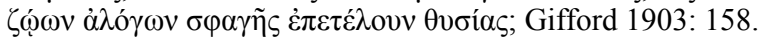

28 Cf. Eusebius, PE IV.10.1. 
29 Porphyry, De abst. II.36.5; Clark 2013: 70. Cited in Eusebius, PE IV.15.1.

30 Porphyry, De abst. I.27.1; Clark 2013: 40.

31 Porphyry, De abst. II.42.2-3; Clark 2013: 73.

32 Porphyry, De abst. II.40.2; Clark 2013: 72.

33 Männlein-Robert 2014: 123 points out that the use of "Feindbilder" is an important strategy in the polemic between Christians and pagan philosophers like Porphyry.

34 Porphyry, De abst. II.40.2; Clark 2013: 72.

35 Eusebius, PE IV.6.2; Gifford 1903: 156.

36 Smith provides less context. However, the sentence that begins before the fragment that is quoted by Smith is important because it gives the impression that Eusebius principally quotes the Philosophia ex oraculis in order to expose Porphyry as a friend of daemons.

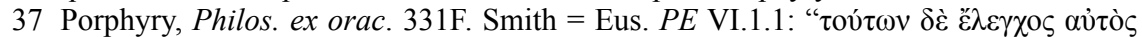

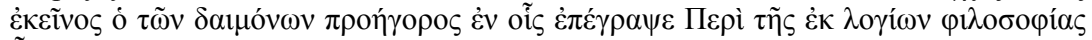

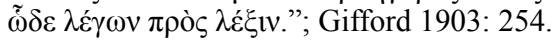

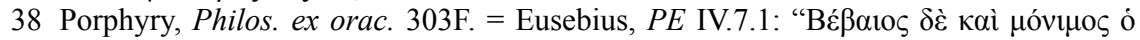

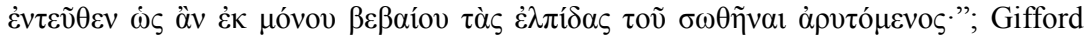
1903: 157.

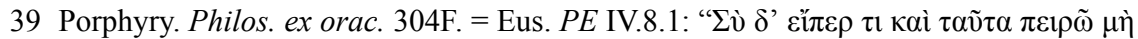

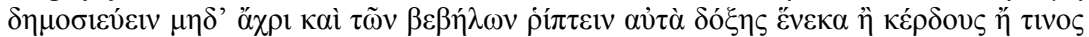

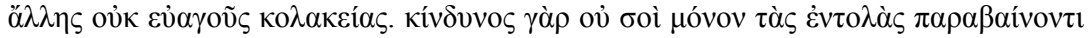

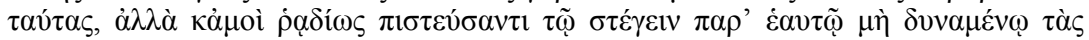

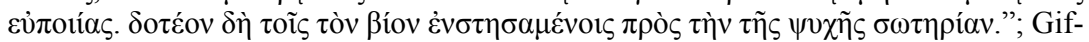
ford 1903: 157-158.

40 Riedweg 2005: 187.

\section{Bibliography}

\section{Primary sources}

\section{a. Editions}

Smith, Andrew (ed.) (1993). Porphyrii Philosophi Fragmenta. Stuttgart: Teubner.

Wolff, Gustav (ed.) (1856). Porphyrii De philosophia ex oraculis haurienda librorum reliquiae. Berlin: Springer.

\section{b. Translations}

Clark, Gillian (trans.) (2013). Porphyry: On Abstinence from Killing Animals. London: Bloomsbury.

Gifford, Edwin Hamilton (trans.) (1903). Eusebii Pamphili Evangelicae Praeparationis Libri XV. Oxford: Typographeus Academicus.

\section{Scholarly literature}

Beatrice, Pier Franco (1988). "Un oracle antichrétien chez Arnobe.” In Mémorial Dom Jean Gribomont (1920-1986), 107-129. Rome: Istitutum Patristicum Augustinianum. (1989). "Quosdam Platonicorum libros: The Platonic Readings of Augustine in Milan.” Vigiliae Christianae 43: 248-281.

(1992). "Towards a New Edition of Porphyry's Fragments against the Christians." In Sophies maietores: 'Chercheurs de sagesse.'Hommage à J. Pépin, ed. Marie-Odile GouletCazé, Goulven Madec and Denis O'Brien, 347-355. Paris: Institut d'Études Augustiniennes. 
(1993). "Antistes philosophiae: Ein christenfeindlicher Propagandist am Hofe Diokletians nach dem Zeugnis des Laktanz." Augustinianum 33: 31-47.

Becker, Matthias (2016). Porphyrios, Contra Christianos: Neue Sammlung der Fragmente, Testimonien und Dubia mit Einleitung, Übersetzung und Anmerkungen. Berlin/ Boston: De Gruyter.

Bidez, Joseph (1913). Vie de Porphyre: Le philosophe néo-platonicien. Gent: van Goethem. Brisson, Luc (2018). "What Is a Daimon for Porphyry?" In Neoplatonic Demons and Angels, ed. Luc Brisson, Seamus O’Neill and Andrei Timotin, 86-101. Leiden/Boston: Brill.

Busine, Aude (2004). "Des logia pour philosophie: À propos du titre de la Philosophie tirée des oracles de Porphyre." Philosophie Antique 4: 149-166.

- (2005). Paroles d'Apollon: Pratiques et traditions oraculaires dans l'Antiquité tardive (IIe-VIe siècles). Leiden/Boston: Brill.

Goulet, Richard (2012). "Porphyre de Tyr I. L'homme et l'œuvre." In Dictionnaire Des Philosophes Antiques. Vol. 5b, 1289-1314. Paris: CNRS.

Hecht, Christine (forthcoming). "Eusebios liest Porphyrios: Fragmentierung und Kontextualisierung der Orakelphilosophie." In Stimmen der Götter. Orakel und ihre Rezeption von der Spätantike bis in die frühe Neuzeit, ed. Helmut Seng, Lucia Maddalena Tissi and Chiara Tommasi Moreschini. Heidelberg: Winter.

Johnson, Aaron P. (2006). Ethnicity and Argument in Eusebius' Praeparatio Evangelica. Oxford: Oxford University Press.

(2013). Religion and Identity in Porphyry of Tyre: The Limits of Hellenism in Late Antiquity. Cambridge: Cambridge University Press.

Magny, Ariane (2014). Porphyry in Fragments: Reception of an Anti-Christian Text in Late Antiquity. Farnham: Ashgate.

Männlein-Robert, Irmgard (2014). "Ordnungskonkurrenz: Polemik und Feindbild in konkurrierenden Ordnungen: Der platonische Philosoph Porphyrios und sein Kampf gegen die Christen." In Aufruhr - Katastrophe - Konkurrenz - Zerfall. Bedrohte Ordnungen als Thema der Kulturwissenschaften, ed. Ewald Frie and Mischa Meier, 117-138. Tübingen: Mohr Siebeck.

Muscolino, Giuseppe (2010). "La demonologia di Porfirio e il culto di Mitra." Mediaeval Sophia: Studi e ricerche sui saperi medievali (E-review semestrale dell'Officina di Studi Medievali 7 (gennaio-giugno)): 103-123.

O'Meara, John Joseph (1959). Porphyry's Philosophy from Oracles in Augustine. Paris: Études Augustiniennes.

- (1969). "Porphyry's Philosophy from Oracles in Eusebius' Praeparatio Evangelica and Augustine's Dialogues of Cassiciacum." Recherches Augustiniennes 6: 103-169.

Riedweg, Christoph (2005). "Porphyrios über Christus und die Christen: Die philosophia ex oraculis haurienda und Contra Christianos im Vergleich." In L'apologétique chrétienne gréco-latine à l'époque prénicénienne, ed. Antonie Wlosok, 151-203. Genève: Fondation Hardt.

Tanaseanu-Döbler, Ilinca (2009). “'Nur der Weise ist Priester': Rituale und Ritualkritik bei Porphyrios." In Religion und Kritik in der Antike, ed. Ulrich Berner and Ilinca Tanaseanu-Döbler, 109-156. Berlin/Münster: Lit.

(2017). "Porphyrios und die Christen in De philosophia ex oraculis haurienda." In Die Christen als Bedrohung? Text, Kontext und Wirkung von Porphyrios' Contra Christianos, ed. Irmgard Männlein-Robert, 137-176. Stuttgart: Franz Steiner Verlag.

Timotin, Andrei (2012). La démonologie platonicienne: Histoire de la notion de daimōn de Platon aux derniers néoplatoniciens. Leiden/Boston: Brill. 


\section{Notes}

1 For the origin of the doctrine of creation out of nothing, see May 1978.

2 The text of Eusebius, Praeparatio Evangelica VII.20 is catalogued by Metzler 2010: 63-66 as fragment D 3.

3 Eusebius, PE VII.20.1.

4 Köckert 2009: 280.

5 As Origen asserts in his treatise: Princ. IV.4.7.

6 Eusebius, $P E$ VII.20.2.

7 Eusebius, $P E$ VII.20.3, about which should be seen the comment in Köckert 2009: 281-282.

8 Eusebius, PE VII.20.4, about which should be seen the comment in Köckert 2009: 282-283.

9 Eusebius, $P E$ VII.20.5. As it shines through in Origen's argument, in the perspective of the Christian doctrine of creation out of nothing (and in a way somewhat similar to the later Neoplatonic authors) the foundation of matter is understood in view of a fundamentally theological orientation.

10 Eusebius, $P E$ VII.20.6.

11 Eusebius, $P E$ VII.20.7.

12 Some traces of the same polemic strategy emerge through the pages of Princ. (e.g. II.1.1). Cf. Boys-Stones 2011.

13 For this hypothesis of dating, see the bibliography cited in Köckert 2009: 312, n. 2.

14 Basil, Hex. II.2.2.

15 Basil, Hex. II.2.4-5.

16 Basil, Hex. II.2.6-7.

17 Basil, Hex. II.2.8.

18 For the various dating hypothesis, see Henke 2000: 16.

19 Ambrose, Exam. I.2.5.

20 See the texts quoted by Pépin 1973: 261-267.

21 Ambrose, Exam. I.7.25 (text translated and analysed in Henke 2000: 182-187).

22 Ambrose, Exam. II.1.1. Regarding this text, see the remarks of Nauroy 2011.

23 For a complete list of the texts under consideration, see Moro 2017: 48-51.

24 Augustine, Conf. XI.5.7. For a more detailed analysis of this text, see Moro 2017: 149-170.

25 Origen, Princ. IV.4.7. On this passage, and on the meaning of the reference to the "bas-

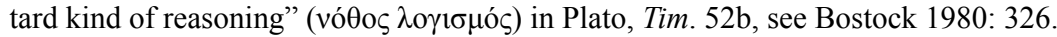

26 Augustine, Conf. XII.5.5. Also in this passage, both on the lexical level and on the conceptual one, the influence of the Platonic text of Tim. 52b and of its reinterpretations by later Platonic thinkers is evident, particularly Plotinus and Calcidius (4th century). For a more detailed analysis of the question, cf. Moro 2017: 184-198.

27 Augustine, Civ. Dei XII.7.

28 Augustine, Conf. XII.6.6.

29 Aristotle, Met. Z 3, 1029a 10-19.

30 A list of textual and bibliographic references can be found in Moro 2017: 208-209.

31 Basil, Hex. I.8.3-4.

32 Cf. Armstrong 1962; Sorabji 1988: 45 (on which we will return later).

33 Cf. Zachhuber 2006; Köckert 2009: 345-347.

34 For an overall analysis of the work, composed in 379 in the aftermath of Basil's death, see Köckert 2009: 400-526.

35 Gregory of Nyssa, In Hex. 7 (Drobner).

36 Gregory of Nyssa, In Hex. 7 (Drobner). In putting the question, it is plausible that Gregory was influenced by the reflection of the Neoplatonic philosopher Porphyry, preserved for us by the Athenian Neoplatonic philosopher Proclus (412-485); for further details, cf. Sorabji 1988: 55.

37 Gregory of Nyssa, In Hex. 7 (Drobner). 


\section{Enrico Moro}

38 Gregory of Nyssa, De hominis opificio 24; Sorabji 1988: 53. Cf. Gregory of Nyssa, De anima et resurrectione, PG 46: $124 \mathrm{~b}-\mathrm{d}$.

39 Cf. Köckert 2009: 415, which translates precisely v̈ $\lambda \eta$ with "materielle Körperlichkeit."

40 See Sorabji 1988: 54-55.

41 See Marmodoro 2015

42 The hypothesis goes back to Armstrong 1962, who refers to Enn. II.4.11, 1-8.

43 I refer to the chapter of Emilsson in this volume, for a more comprehensive account of matter (and its relation to badness) in Plotinus.

44 For a balanced discussion of the question, cf. Chiaradonna 2016; Emilsson 2017: 203-214.

45 In this regard, see the critical remarks formulated by Köckert 2009: 420-421.

46 This observation was first proposed by Alexandre 1976: 166-169.

47 Origen, Princ. IV.4.7.

48 I summarise here the reading of Köckert 2009: 421-424.

49 Cf. e.g. Augustine, Conf. XII.6.6; 8.8; 17.25; 19.28; Civ. Dei XXII.19.

50 Cf. e.g. Augustine, Conf. XII.15.19; 17.25-26; 22.31.

51 On the fundamental difference between Plotinus' and Augustine's conception of matter on this point, see Moro 2018.

52 See Theiler 1933: 13-14.

53 The section of Porphyry's commentary is handed down to us by Proclus, In Tim. I, 391.4-396.26 (= fr. 51, ed. Sodano), on the content of which see Baltes 1976: 221.

54 This expression appears in Proclus, In Tim. I, 392.8. On the use of the concept of $\dot{\varepsilon} \pi \imath \tau\lceil\delta \varepsilon ı$ ó $\rceil$ in and before Porphyry, cf. Pavlos 2017.

55 On this point, see the analysis of Rescigno 1997.

56 This has been convincingly shown by Du Roy 1966, who considers it unnecessary to hypothesise a Porphyrian direct influence with respect to the theme of the capacitas formae.

57 As is frequently the case in Plotinus (e.g. Enn. I.6.2, II.4.5, II.5.5, III.6.13, I.8.3, 8) and, moreover, in Porphyry himself (e.g. Sent. 20; 30; De abst. III.27).

58 On Porphyry's conception of the origin of matter, see: Aeneas of Gaza, Theophrastus 175.2-9 (= fr. 368F. Smith); John Lydus, De mensibus 175.2-9; Simplicius, In Aristotelis Physicorum libros quattuor priores commentaria, 230.34-231.24 (= fr. 236F. Smith). For a careful discussion of these texts, see Tornau 2000.

59 Theoretically, it is possible that Augustine became aware of some aspects of Porphyry's reflection via Calcidius: cf. Bakhouche and Brisson 2011: 47-53.

60 For a complete list of textual references, cf. Moro 2017: 137-138.

61 See Philo of Alexandria, De opificio mundi VI.23; De providentia II.50-51; Eusebius, $P E$ VII.20-21. Among patristic thinkers, it is Origen, above all, who strongly emphasises the complete "availability" with regard to the divine action which matter possesses precisely because created by God: see Princ. II.4.1; III.6.4; III.6.7.

62 Cf. Cicero, De natura deorum, III.xxxix.92, and the comment on this text in Brisson 2002: 32 .

63 As it has been suggested, instead, by Bouton-Touboulic 2004: 72.

64 For a complete list of textual references, see Moro 2017: 140.

\section{Bibliography}

\section{Primary sources}

\section{a. Editions}

Bandy, Anastasius C., Anastasia Bandy, Demetrios J. Constantelos, and Craig J. N. de Paulo (eds.). Preface edited by Michael Maas. (2013). Iohannes Lydus, De mensibus: On the Months. Lewiston: The Edwin Mellen Press. 
Bouffartigue, Jean and Michel Pattilon (eds.) (1977-2003). Porphyre, De l'abstinence. 3 vols. Paris: Les Belles Lettres.

Brisson, Luc (ed.) (2005). Porphyre, Sentences: Études d'introduction, texte grec et traduction française, commentaire. 2 vols. With English translation by John M. Dillon. Paris: Vrin.

Burnet, John (ed.) (1905). Platonis Opera. Vol. 4. Oxford: Clarendon Press.

Cohn, Leopold (ed.) (1967). Philonis Alexandrinus Libellus de opificio mundi. Hildesheim: G. Olms.

Colonna, Elisabetta Maria (ed.) (1958). Teofrasto. Napoli: Iodice.

Crouzel, Henri and Manlio Simonetti (eds.) (1978-1980). Origène, Traité des principes. 2 vols. Paris: Le Cerf.

de Mendieta, Emmanuel Amand and Stig J. Rudberg (eds.) (1997). Basilius von Caesarea, Homilien zum Hexaemeron. Berlin: Akademie Verlag.

Diehl, Ernst (ed.) (1903-1906). Porphyrii In Platonis Timaeum commentaria. 3 vols. Amsterdam: A.M. Hakkert.

Diels, Hermann (ed.) (1882). Simplicius, In Aristotelis Physicorum libros quattuor priores commentaria (CAG, 9). Berlin: Reimer.

Dombart, Bernhard and Alphons Kalb (eds.) (1955). Sancti Aurelii Augustini De civitate dei libi, I-XI; XI-XII. CCSL. 2 vols, 47-48. Turnhout: Brepols.

Drobner, Hubertus R. (ed.) (2009). Gregorii Nysseni Opera Exegetica in Genesim, 4.1: In Hexaemeron. Leiden: Brill.

Gerlach, Wofgang and Karl Bayer (eds.) (1978). M. Tulli Ciceronis De natura deorum libri tres. Munich: Heimeran Verlag.

Hadas-Lebel, Mireille (ed.) (1973). Philon d'Alexandrie, De providentia I-II. Paris: Cerf.

Henry, Paul and Hans-Rudolf Schwyzer (eds.) (1964-1982). Plotini Opera. 3 vols. Oxford: Clarendon Press.

Jaeger, Werner (ed.) (1957). Aristotelis Metaphysica. Oxford: Clarendon Press.

Migne, Jacques-Paul (ed.) (1863). "S. Gregorius Nyssenus, De opificio hominis." In PG. Vol. 44, cols. 123-298. Paris: Imprimerie Catholique.

Mras, Karl and Édouard Des Places (eds.) (1982-1983). Eusebius, Die Praeparatio Evangelica. 2 vols. Berlin: Akademie Verlag.

Schenkl, Karl (ed.) (1987). Sancti Ambrosi Exameron. CSEL. Vol. 32.1, 1-261. Prague/ Wien/Leipzig: Tempsky-Freytag.

Smith, Andrew (ed.) (1993). Porphyrii philosophi fragmenta. Stuttgart: Teubner.

Sodano, Angelo R. (ed.) (1964). Porphyrii In Platonis Timaeum commentariorum fragmenta. Napoli: Istituto della Stampa.

Spira, Andreas and Ekkehard Mühlenberg (eds.) (2014). Gregorii Nysseni Opera dogmatica minora, 3: De Anima et resurrectione. Leiden/Boston: Brill.

Verheijen, Luc (ed.) (1981). Sancti Aurelii Augustini Confessionum libri tredecim. CCSL. Vol. 27. Turnhout: Brepols.

\section{Scholarly literature}

Alexandre, Monique (1976). "L'exégèse de Gen 1, 1-2a dans l'Hexaemeron de Grégoire de Nysse: deux approches au problème de la matière." In Gregor von Nyssa und die Philosophie, ed. Heinrich Dörrie, Margarete Altenburger and Uta Schramm, 159-192. Leiden: Brill.

Armstrong, Arthur H. (1962). "The Theory of the Non-Existence of Matter in Plotinus and the Cappadocians." Studia Patristica 5: 427-429. 
Bakhouche, Sabine and Luc Brisson (eds.) (2011). Calcidius, Commentaire au Timée de Platon. Édition critique et traduction française. Paris: Vrin.

Baltes, Mathias (1976). Die Weltentstehung des platonischen Timaios nach den antiken Interpreten (Teil I). Leiden: Brill.

Bostock, David (1980). "Quality and Corporeity in Origen." In Origeniana secunda. Second Colloque International des études origeniennes (Bari, 20-23 septembre 1977), ed. Henri Crouzel and Andrea Quacquarelli, 323-337. Rome: Edizioni dell'Ateneo.

Bouton-Touboulic, Anne-Isabelle (2004). L'ordre caché: La notion d'ordre chez saint Augustin. Paris: Institut d'Études Augustiniennes.

Boys-Stones, George R. (2011). "Time, Creation, and the Mind of God: The Afterlife of a Platonist Theory in Origen." Oxford Studies of Ancient Philosophy 40: 319-337.

Brisson, Luc (2002). "Le démiurge du Timée et le créateur de la Genèse." In Le style de la pensée: Recueil de textes en hommage à Jacques Brunschwig, ed. Monique Canto Sperber and Pierre Pellegrin, 25-39. Paris: Les Belles Lettres.

Chiaradonna, Riccardo (2016). "La materia e i composti sensibili nella filosofia di Plotino." In Materia e causa materiale in Aristotele e oltre, ed. Cristina Viano, 149-170. Roma: Edizioni di Storia e Letteratura.

Du Roy, Olivier (1966). L'intelligence de la foi en la Trinité selon Saint Augustin: Genèse de sa théologie trinitaire jusqu'en 391. Paris: Études Augustiniennes.

Emilsson, Eyjólfur K. (2017). Plotinus. London/New York: Routledge.

Henke, Rainer (2000). Basilius und Ambrosius über das Sechstagewerk: Eine vergleichende Studie. Basel: Schwabe \& Co.

Köckert, Charlotte (2009). Christliche Kosmologie und kaiserzeitliche Philosophie: Die Auslegung des Schöpfungsberichtes bei Origenes, Basilius und Gregor von Nyssa vor dem Hintergrund kaiserzeitlicher Timaeus-Interpretationen. Tübingen: Mohr Siebeck.

Marmodoro, Anna (2015). "Gregory of Nyssa on the Creation of the World." In Causation and Creation in Late Antiquity, ed. Anna Marmodoro and Brian D. Prince, 94-110. Cambridge: Cambridge University Press.

May, Gerhard (1978). Schöpfung aus dem Nichts. Berlin: De Gruyter.

Metzler, Karin (ed.) (2010). Origenes, Die Kommentierung des Buches Genesis. Berlin/ New York/Freiburg: De Gruyter/Herder.

Moro, Enrico (2017). Il concetto di materia in Agostino. Preface by Giovanni Catapano. Canterano, Rome: Aracne.

- (2018). "Augustine and Plotinus on the Matter of the Corporeal World." Augustiniana 68.1: 7-24.

Nauroy, Gérard (2011). “Ambroise de Milan, émule critique de Basil de Césarée: À propos de Genèse 1, 2.” In La Création chez les Pères, ed. Marie-Anne Vannier, 77-101. Bern: Peter Lang.

Pavlos, Panagiotis G. (2017). 'Christian Insights into Plotinus' Metaphysics and His Con-

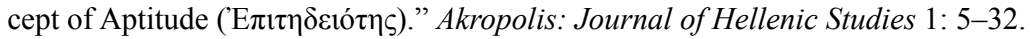

Pépin, Jean (1973). "Echos de théories gnostiques de la matière au debut de l'Exameron." In Romanitas et christianitas: Studia Jan Hendrik Waszink oblata, ed. Willem den Boer, Pieter G. Van der Nat and Jacobus C.M. Van Winden, 259-273. Amsterdam/London: North Holland Publishing Company.

Rescigno, Andrea (1997). "Desiderare componi a deo: Attico, Plutarco, Numenio sulla materia prima della creazione.” KOINONIA 21: 39-81.

Sorabji, Richard (1988). Matter, Space and Motion. London/Ithaca, NY: Cornell University Press.

Theiler, Willy (1933). Porphyrios und Augustin. Schriften der Königsberger Gelehrten Gesellschaft, Geisteswiss. Klasse 10/1. Halle: Niemeyer. 
Tornau, Christian (2000). "Die Prinzipienlehre des Moderatos von Gades. Zu Simplikios in Ph. 230, 34-231, 24 Diels.” Rheinisches Museum für Philologie 143: 197-222.

Zachhuber, Johannes (2006). "Stoic Substance, Non-Existent Matter? Some Passages in Basil of Cesarea Clarified." In Studia Patristica, Vol. 41, Papers Presented at the Fourteenth International Conference on Patristic Studies Held in Oxford 2003, Orientalia, Clement, Origen, Athanasius, The Cappadocians, Chrysostom, ed. Frances Young, Mark J. Edwards and Paul M. Parvis, 425-430. Leuven: Peeters. 
or thereafter. One reason is no doubt the accident of Pseudo-Dionysius' immense influence - his views on the issue strongly reflect Proclus' position as opposed to Plotinus'.

\section{Notes}

1 I wish to thank my colleagues and friends, the professors Thomas K. Johansen, Pavlos Kalligas, Jan Opsomer, Damian Caluori, and Suzanne Stern-Gillet, all of whom have read and given me valuable comments on drafts of this chapter at different stages. I also wish to thank my co-editors Lars Fredrik Janby and Panagiotis G. Pavlos, who assisted me at final stages. Further, I want to thank the audiences at the University of Iceland and the seminar of the Society of Ancient Philosophy at the University of Oslo where I have presented earlier versions. I learnt from the discussion on both occasions. Furthermore, I wish to note that although this chapter was written for the present volume, with the permission of Routledge a version of it in Icelandic will first appear in the journal Hugur.

2 In chapter 6 of Enn. I.8., Plotinus argues that the Good and matter are opposites. This involves introducing a wider sense of "opposite" than Aristotle's Categories 5 allow for: primary being (ousia) has no contrary according to Aristotle. Plotinus seems to take this as implying that that which is beyond being, i.e. the Good, cannot have a contrary either. He argues against this, concluding that "But things which are completely separate, and in which there are present in the one the contraries to whatever is the fulfillment of the being of the other, must surely be most of all contraries, if 'by contraries we mean things that are furthest removed from each other"' (Enn. I.8.6, 38-41; cf. Cat. 6, 6a17-18).

3 For this aspect of Stoicism, see Michael Frede (2011), chapter 5.

4 E.g. Plato, Theaet. 176, Rep. 379c; 617e, Tim. 29e-30a.

5 Plutarch, De anima procreatione in Timaeo 1014b; Proclus, In Tim. I, 382.5-7.

6 See also Numenius, fr. 52 (des Places) and Iamblichus' account of previous Platonist views in De anima 23.

7 For a short overview of ancient authors addressing this question, see O'Meara 1999: 91-92. See also Enrico Moro's chapter in this volume.

8 O'Brien 1969.

9 O'Brien has since forcefully and industriously defended and expounded his view of matter as generated by the lowest phase of the World-Soul in a number of publications: I refer here only to his O'Brien 1971, 1996, 1999 and his latest 2011a, $2011 \mathrm{~b}$ and 2012. There are several more.

10 Among dissenting voices we find Hans-Rudolph Schwyzer 1973, who held that for Plotinus matter is ungenerated; Kevin Corrigan 1986, who argues for multiple generations of matter; Jean-Marc Narbonne 2007, who holds sensible matter to be generated from intelligible matter, and John Phillips 2009, to whom O'Brien responds in his three latest articles listed in the bibliography.

11 A slightly earlier treatise, "On providence" (Enn. III.2. [47] and III.3 [48]), might suggest that Plotinus essentially gives the Stoic answers that I also dubbed as the Christian ones: the evils aren't bad after all and that you will see this if you adopt a wider perspective on the cosmos and, secondly, that badness is the result of human failure having to do with our freedom of choice, cf. St. Augustine, De Ordine 1.1.1-1.2.3 and De libero arbitrio, especially book 1 . How these accounts can be harmonised with claiming matter to be the root of evil I shall not address here.

12 There is considerable scholarly literature dealing with Proclus' objections. The following are those that I have found particularly illuminating and, in some cases, also challenging: Dominic O'Meara 1998, "Evil in Plotinus," where he discusses Proclus' objections without taking a clear stand on the dispute. There is Jan Opsomer's 2001 
article in Phronesis "Proclus vs. Plotinus on Matter (De mal. subs. 30-7)," clearly siding with Proclus; O'Meara 2005 is again out with an article in a Festschrift for Denis O'Brien, "The Metaphysics of Evil in Plotinus." Christian Schäfer comes to Plotinus' defense in Phronesis in 2004 but at the cost of denying that matter is badness as such. Opsomer again critically assesses O'Meara's and Schäfer's articles in Opsomer 2007, putting up a strong defense for Proclus' viewpoints.

13 De malorum subsistentia is the last one of three short treatises, together referred to as Tria opuscula, the other ones being De libertate and De providentia. These treatises are extant only in William of Moerbeke's Latin 13th century translation. There is a fine English translation in Opsomer and Steel 2003.

14 See especially Proclus, De mal. subs. 32.

15 See De mal. subs. 31.18-21.

16 Opsomer 2007: 180.

17 Ibid.

18 On goodness after its kind, see Georg Henrik von Wright 1963: 19-20.

19 See von Wright 1963: 23.

20 Cf. Aristotle, Met. 12, 1072 b 14.

21 The view that the realm of soul also belongs to what truly is pervasive in the Enneads but is hammered in especially strongly in "On the presence of being, one and the same, everywhere as a whole" (VI.4. - 5. [24-25]).

22 Plotinus, Enn. I.8.3, 22-25. The translation of Plotinus' text here and elsewhere in this chapter is substantially that of Armstrong in the Loeb Classical Library but usually with modifications.

23 O'Meara 1999: 109-110.

24 Opsomer 2007: 180.

25 The views of Schäfer and Opsomer differ importantly, however, in that the former thinks that Plotinus too does not hold matter to be bad in itself, a view with which Opsomer disagrees. I am sure that Opsomer is right on this.

26 Opsomer 2007: 183.

27 Plotinus, Enn. I.8.4, 1-6.

28 The following paragraphs expand on the account of matter, bodies and spatiality in Emilsson 2017: 200-204.

29 To say that matter becomes a bulk is a manner of speaking: strictly speaking matter never becomes anything.

30 On the notion of bulk (onkos) in Plotinus, see Brisson 2000.

31 For the individuation of bodies, their parts and qualities, see Enn. IV.2. [4] 1, 11-17; 36-41; Enn. VI.4. [22] 1, 17-26 and Emilsson 1990.

32 On Plotinus' doctrine of the inaffectability of matter, see Christopher Isaac Noble 2013.

33 Later Neoplatonic commentators note Plotinus' doctrine about "the battle for place" in the sensible realm: see Elias, In Porphyrii Isagogen, 85.14-17; In Aristotelis Categorias 5, 179.1-13; David, In Porphyrii Isagogen 18,149.6-11.

34 Plotinus, Enn. III.2.1, 27-35.

35 Plotinus, Enn. I.8.5, 21-26.

36 In the slightly earlier treatise on providence, Enn. III.2. and 3. [47-48], he goes on about the conflicts inherent to the sensible world. The sense one gets is that these are all part of what is determined by providence.

37 See Enn. I.1. [53] 7-11. "What is the living being and what is man."

38 Enn. V.1. [10] 10, 11, "On the three principal hypostases," and Enn. IV.8. [6] 8, 2, "On the descent of soul into bodies."

39 Cf. Plato, Symp. 206d.

40 Plotinus, Enn. I.8.14, 44-49.

41 The doctrine of the inaffectability of the soul is thoroughly discussed in a recent article by Christopher Isaac Noble 2016. See also Emilsson 2017: 161-165 and Caluori 2015: 152-163. 
42 Fleet 1995: commentary ad loc.

43 Plotinus, Enn. I.8.8, 3-9.

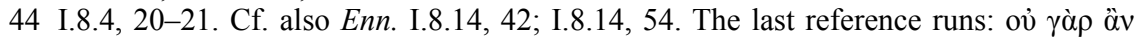

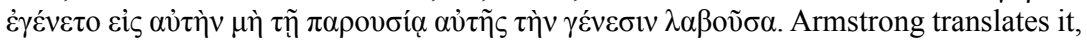
I think wrongly or at least misleadingly, as: "soul would not have come to it [matter] unless its presence had given soul the occasion of coming to birth." O'Meara 1999: 83 translation, which recognises the notion of becoming at play here, is in my view better: "Car l'âme ne serait pas venue vers la matière, si, à cause de la presence da la matière, elle n'avait pas eu l'occasion d'entrer dans le devenir."

45 This is clearly laid out in Caluori 2015, chapter 6. Plotinus' choice of the word, "being cramped" is no doubt an allusion to Plato, Symp. 206d, as $\mathrm{HS}_{2}$ note in their apparatus.

46 Plotinus, Enn. I.8.7, 16-22.

47 This principle is what is called Axiom 1 in Opsomer 2007.

48 Neither the Good nor matter, and these alone, have being and both are described as apeira (infinite, indefinite). On the peculiarities in the mode of production of matter, see O'Brien 1996: 182-183.

49 See Moro's chapter in this volume.

\section{Bibliography}

\section{Primary sources}

\section{a. Editions}

Armstrong, Arthur Hilary (ed. and trans.) (1966-1982). Plotinus, Enneads. LCL. 7 vols. Cambridge, MA: Harvard University Press.

Fleet, Barrie (ed. and trans.) (1995). Plotinus: Ennead III.6: On the Impassivity of the Bodiless, with a Translation and Commentary. Oxford: Clarendon Press.

Henry, Paul and Hans-Rudolf Schwyzer (eds.) (1964-1982). Plotini Opera I-III. Editio Minor, with Revised Text. Oxford: Clarendon Press. Abbreviated $\mathrm{HS}_{2}$.

\section{b. Translations}

O’Meara, Dominic J. (1999). Plotin: traité 51, I. 8. Introduction, traduction, commentaires et notes par Dominic O'Meara. Paris: Le Cerf.

Opsomer, Jan and Carlos Steel (trans.) (2003). Proclus: On the Existence of Evils. Ancient Commentators on Aristotle. London: Duckworth.

\section{Scholarly literature}

Brisson, Luc (2000). "Entre métaphysique et physique: Le terme ö $\gamma \kappa \varsigma_{\text {co }}$ chez Plotin, dans ses rapports avec la matière (vँ $\lambda \eta)$ et le corps $(\sigma \tilde{\omega} \mu \alpha)$." In Études sur Plotin, ed. Michel Fattal, 87-111. Paris/Montréal: L'Harmattan.

Caluori, Damian (2015). Plotinus on the Soul. Cambridge: Cambridge University Press.

Corrigan, Kevin (1986). "Is There More Than One Generation of Matter in the Enneads?" Phronesis 31.2: 167-181.

Emilsson, Eyjólfur K. (1990). "Reflections on Plotinus' Ennead IV.2." In Greek and Latin Studies in Memory of Cajus Fabricius, ed. Sven-Tage Teodorsson. Studia Graeca and Latina Gothoburgensia. Vol. 54, 206-219. Gothenburg: Acta Universitatis Gothoburgensis. (2017). Plotinus. London: Routledge. 
Frede, Michael (2011). A Free Will: Origins of the Notion in Ancient Thought. Berkeley/ Los Angeles: University of California Press.

Narbonne, Jean-Marc (2007). "La controverse à propos de la génération de la matière chez Plotin: l'énigme résolue?" Quaestio 7: 123-163.

Noble, Christopher Isaac (2013). "Plotinus' Unaffectable Matter." Oxford Studies in Ancient Philosophy 44: 233-277. Oxford: Oxford University Press.

- (2016). "Plotinus' Unaffectable Soul." Oxford Studies in Ancient Philosophy 51: 231-281. Oxford: Oxford University Press.

O'Brien, Denis (1969). "Plotinus on Evil: A Study of Matter and the Soul in Plotinus' Conception of Human Evil." Downside Review 87: 68-110; an enlarged and modified version with the same title appeared in O'Brien (1971), Le néoplatonisme: Royaumont, 9-13 Juin 1969 (Colloques internationaux du Centre national de la recherche scientifique, Sciences humaines 535), ed. Pierre-Maxime Schuhl, 113-146. Paris: CNRS Éditions.

(1996). "Plotinus on Matter and Evil." In The Cambridge Companion to Plotinus, ed. Lloyd P. Gerson, 171-195. Cambridge: Cambridge University Press.

(1999). "La matière chez Plotin: Son origine, sa nature." Phronesis 44.1: 45-71.

(2011a). "Plotinus on the Making of Matter Part I: The Identity of the Darkness." Journal of the Platonic Tradition 5.2: 6-57.

(2011b). "Plotinus on the Making of Matter Part II: 'A Corpse Adorned' (Enn. II 4

[12] 5.18).” Journal of the Platonic Tradition 5.2: 209-261.

(2012). "Plotinus on the Making of Matter Part III: The Essential Background." Journal of the Platonic Tradition 6.1: 27-80.

O'Meara, Dominic J. (1998). "Evil in Plotinus." In The Structure of Being and the Search for the Good: Essays on Ancient and Early Medieval Platonism, ed. Dominic J. O'Meara, IX. Aldershot: Ashgate. German original in: Platon in der abendländischen Geistesgeschichte, ed. Theo Kobusch and Burkhard Mojsisch, 1-15. Darmstadt: Wissenschaftliche Buchgesellschaft, 1997.

(2005). "The Metaphysics of Evil in Plotinus: Problems and Solutions." In Agonistes: Essays in Honour of Denis O'Brien, ed. John M. Dillon and Monique Dixsaut, 179-185. Aldershot: Ashgate.

Opsomer, Jan (2001). "Proclus vs. Plotinus on Matter (De Mal. Subs. 30-7)." Phronesis 46.2: $154-188$.

(2007). "Some Problems with Plotinus' Theory of Matter/Evil: An Ancient Debate Continued." Quaestio 7.1: 165-189.

Phillips, John (2009). "Plotinus on the Generation of Matter." The International Journal of the Platonic Tradition 3.2: 103-137.

Schäfer, Christian (2004). "Matter in Plotinus's Normative Ontology." Phronesis 49.3: 266-294.

Schwyzer, Hans-Rudolph (1973). "Zu Plotins Deutung der sogennanten platonischen Materie.” In Zetesis: Festschrift E. de Strijker, ed. Th. Lefevre, 266-280. Antwerp/ Utrecht: Nederlandsche Boekhandel.

von Wright, Georg Henrik (1963). The Varieties of Goodness. London: Routledge/Kegan Paul. 
all-powerful character or omnipotence of God. According to Sorabji many ancient philosophers denied attributes like this. ${ }^{65}$ The Christian notion of omnipotence is combined with a distinctive view of divine goodness implying that the deity loves and cares for particular beings. Late antique pagan philosophers disagreed on the extension of providence. ${ }^{66}$ For some (like Alexander of Aphrodisias) providence is not concerned with individuals but only with the species while other thinkers (like Proclus) hold that it extends to everything, even if in a non-specific way. The Christian God creates the cosmos not because He has to but because He wills. As we have seen, this will be directed to the making of particular beings at the appropriate time, i.e. when it is good for them to come into existence. The attention of the Christian God is therefore focused on the things He makes in a lot more emphatic way than that of any Neoplatonic divinity.

One aspect of the doctrine of an all-powerful God is that there is no need for any sensible stuff to exist simultaneously (in whatever condition) with the divinity from eternity. This is an old Christian objection to Platonist cosmologies. It is already found in Athanasius of Alexandria who criticises the Platonists for holding that God would be unable to make anything unless matter already existed, "just as a carpenter must have wood first in order to be able to fashion it." 67 In this way one is imputing weakness to God. Athanasius concludes that God in that case will only be a craftsman ( $\tau \varepsilon \chi v i ́ \tau \eta \varsigma)$ and not a creator ( $\kappa \tau i ́ \sigma \tau \eta \varsigma)$. This objection is probably directed against Platonist cosmologies which held that the present cosmos has a beginning and that matter eternally predated this beginning. However, one does not find such a doctrine in Plotinus who lived earlier than Athanasius or in Proclus who is later. There is no temporal beginning of the present cosmos, and therefore unformed matter does not exist temporally before the present age. Even if the two important figures of Plotinus and Proclus did not teach such a thing, the opinion that this was a common Platonist doctrine was repeated in the writings of Christian thinkers for centuries.

\section{Notes}

1 Basil, Hex. 1.6; English translation in Way 1983: 10. Greek text in Basile de Césarée, Homélies sur l'hexaéméron, Giet 1968: 110.

2 Maximus, Car. 4.5, PG 90: 1048d.

3 Aeneas of Gaza: Theophrastus with Zacharias of Mytilene: Ammonius, translated in Gertz et al. 2012.

4 For Aeneas and Zacharias and their milieu, see Champion 2014.

5 Sorabji 1983: 224.

6 Share's introduction to Philoponus, in Share 2004: 7. I wonder, is there a misprint here, should not 'imminent' be "immanent?"

7 Proclus, In Tim. 277; English translation of Proclus, Commentary on Plato's Timaeus, in Runia and Share 2008: 128. The distinction between being and becoming of course reflects Plato's usage in Tim. 27d-28a.

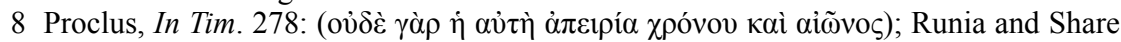
2008: 128.

9 Aristotle, Phys. 3, chapter 6.

10 Sorabji 2004: 175.

11 Proclus, In Tim. 282; Runia and Share 2008: 134. 


\section{Torstein Theodor Tollefsen}

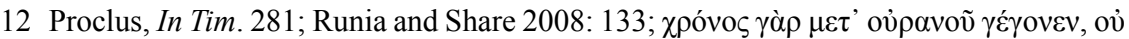

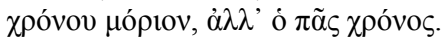

13 Somehow this picture of the cosmos could be compared with Parmenides' "way of

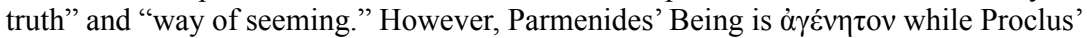
world is characterised by "generation." Even so, see Parmenides' fragment 8.

14 Philoponus, Contra Proclum 24; translation in John Philoponus, Against Proclus On the Eternity of the World 1-5, Share 2004: 32.

15 Philoponus, Contra Proclum 33-36; Share 2004: 37-38.

16 Philoponus, Contra Proclum 36-37; Share 2004: 39.

17 Cf. the Living Creature in Plato, Tim. 30c.

18 Philoponus, Contra Proclum 33-36; Share 2004: 37-39.

19 Philoponus, Contra Proclum 36-37; Share 2004: 39.

20 Philoponus, Contra Proclum 40; Share 2004: 41.

21 This distinction becomes classical. It is found in Thomas Aquinas as well.

22 Philoponus, Contra Proclum 42-43; Share 2004: 42-43.

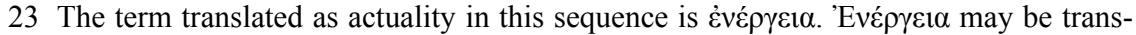
lated as activity as well. One should keep in mind that the term actuality is to be understood in a "dynamic" sense as being in activity.

24 Philoponus, Contra Proclum 46-47; Share 2004: 44-45.

25 Philoponus, Contra Proclum 55-56; Share 2004: 50.

26 Philoponus, Contra Proclum 63; Share 2004: 54.

27 Ibid.

28 Philoponus, Contra Proclum 64; Share 2004: 55.

29 Philoponus, Contra Proclum 78; Share 2004: 63.

30 Philoponus, Contra Proclum 79; Share 2004: 64.

31 Philoponus, Contra Proclum 566; Philoponus, Against Proclus' On the Eternity of the World 12-18, translated in Wilberding 2006: 70.

32 Maximus, Amb. Io. 7, PG 91: 1081a; Constas 2014: 100-101.

33 Maximus, Car. 4.4, PG 90: 1048d.

34 Maximus, Car. 4.3, PG 90: 1048c.

35 Cf. Maximus, Car. 4.3-5, PG 90: 1048c-d.

36 Cf. Tollefsen 2008: 45-46.

37 Philoponus, Contra Proclum 119; Philoponus, Against Proclus On the Eternity of the World 6-8, translated in Share 2005: 13.

38 Philoponus, Contra Proclum 235; Share 2005: 82.

39 Philoponus, Contra Proclum 236; Share 2005: 83.

40 Diogenes Laertius II, 7, Zeno 141, in Hicks' translation (LCL) 244-245: “And that of which the parts are perishable is perishable as a whole. Now the parts of the world are perishable, seeing that they are transformed one into another. Therefore the world itself is doomed to perish."

41 Basil, Hex. 1.3, Giet 1968: 100; Way 1983: 7.

42 Sorabji 1987: 8, 30.

43 Cf. Sorabji 1987: 84.

44 Sorabji 2004: 348.

45 A relevant section from Philoponus' In Phys. is translated in Sorabji 2004: 351-352.

46 God is implanting motive power into the cosmic building, cf. the text from Philoponus, De opificio mundi translated in Sorabji 2004: 350.

47 Cf. the quotation from Proclus, In Tim., in Sorabji 2004: 355.

48 We find these arguments both in his Contra Proclum and in Contra Aristotelem. For a translation of the latter cf. John Philoponus, Against Aristotle on the Eternity of the World, Wilberding 1987: 143-146, fragment 132. Cf. the essentials of the argument presented in Sorabji 2004: 179-180. 
49 Philoponus, Contra Proclum 552; Wilberding 2006: 62.

50 Philoponus, Contra Proclum 618-20; Wilberding 2006: 100-101.

51 Maximus, Car. 4.5, PG 90: 1048d.

52 Maximus, Amb. Io. 7, PG 91: 1077c. That the world is created out of nothing is often considered to be a distinctive mark of Christian doctrine. However, one should compare this claim with what Proclus says in his commentary In Tim. 281; Runia and Share

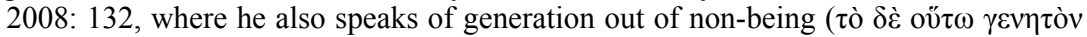

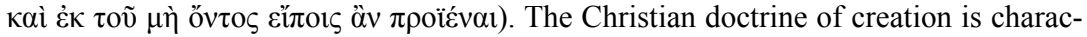
terised by several additional claims, such as that there is a divine plan, that God creates out of love, that the world has a temporal beginning.

53 Maximus, Amb. Io. 7, PG 91: 1081a-b; Constas 2014: 100-101.

54 Maximus, Amb. Io. 10, PG 91: 1176d-1188c; Constas 2014: 284-309.

55 Plato, Tim. 27d-28a.

56 Plato, Tim. 28bc.

57 Plato, Tim. 30a.

58 Maximus, Amb. Io. 10, PG 91: 1176d-1177b; Constas 2014: 285-287.

59 Maximus, Amb. Io. 10, PG 91: 1177a; Constas 2014: 285-287.

60 Maximus, Amb. Io. 10, PG 91: 1177b-1181a; Constas 2014: 289-295.

61 Philoponus, Contra Proclum 236; Share 2005: 83.

62 Plato, Tim. 30ab.

63 Basil, Hex. 2.2, 148; Way 1983: 24.

64 Proclus, In Tim. 398-399; Runia and Share 2008: 273-275. Cf. note 381.

65 Sorabji 2004: 69.

66 For a summary of positions, see Sorabji 2004: 79-95.

67 Athanasius, Contra Gentes and De Incarnatione, edited and translated in Thomson 1971: 138-139.

\section{Bibliography}

\section{Primary sources}

\section{a. Editions}

Constas, Nicholas (ed. and trans.) (2014). Maximos the Confessor, on Difficulties in the Church Fathers: The Ambigua. Vols. 1 and 2. Dumbarton Oaks Medieval Library 28-29. Cambridge, MA: Harvard University Press.

Diehl, Ernst (ed.) (1903). Procli Diadochi In Platonis Timaeum Commentaria I. Leipzig: Bibliotheca Teubneriana.

Giet, Stanislas (ed. and trans.) (1968). Basile de Césarée, Homélies sur l’hexaéméron. Paris: Le Cerf.

Hicks, Robert Drew (ed.) (1925). Diogenes Laertius, Lives of Eminent Philosophers. Vol. 2. Cambridge, MA: Harvard University Press.

Migne, Jacques-Paul (ed.) (1857-1866). Maximi Confessoris Opera Omnia. PG. Vols. 90-91. Paris: Imprimerie Catholique.

Rabe, Hugo (ed.) (1963). Ioannes Philoponus, De aeternitate mundi contra Proclum. Leipzig: Bibliotheca Teubneriana.

Ross, William D. (ed.) (1950). Aristotle, Physica. Oxford: Clarendon Press.

Thomson, Robert W. (ed. and trans.) (1971). Athanasius, Contra Gentes and De Incarnatione. Oxford: Clarendon Press. 


\section{Torstein Theodor Tollefsen}

\section{b. Translations}

Bury, Robert Gregg (trans.) (1929). Plato, Timaeus, Critias, Cleitophon, Menexenus, Epistles. LCL. Cambridge, MA: Harvard University Press.

Gertz, Sebastian, John Dillon and Donald Russell (trans.) (2012). Aeneas of Gaza: Theophrastus with Zacharias of Mytilene: Ammonius. London: Bloomsbury.

Runia, David T. and Michael Share (trans.) (2008). Proclus, Commentary on Plato's Timaeus. Vol. 2. Cambridge: Cambridge University Press.

Share, Michael (trans.) (2004). Philoponus, Against Proclus on the Eternity of the World 1-5. London: Duckworth.

(trans.) (2005). Philoponus, Against Proclus on the Eternity of the World 6-8. London: Duckworth.

Way, Sister Agnes Claire, C.D.P. (trans.) (1983). Saint Basil, Exegetic Homilies. Washington, DC: Catholic University of America Press.

Wilberding, James (trans.) (1987). Philoponus, Against Aristotle on the Eternity of the World. London: Duckworth.

(trans.) (2006). Philoponus, Against Proclus' on the Eternity of the World 12-18. London: Duckworth.

\section{Scholarly literature}

Champion, Michael W. (2014). Explaining the Cosmos: Creation and Cultural Interaction in Late-Antique Gaza. Oxford: Oxford University Press.

Kirk, Geoffrey Stephen and John Earle Raven (eds.) (1957). The Presocratic Philosophers. Cambridge: Cambridge University Press.

Sorabji, Richard (1983). Time, Creation and the Continuum. London: Duckworth. (ed.) (1987). Philoponus and the Rejection of Aristotelian Science. London: Duckworth.

(2004). The Philosophy of the Commentators 200-600 AD. Vol. 2, Physics. London: Duckworth.

Tollefsen, Torstein Theodor (2008). The Christocentric Cosmology of St Maximus the Confessor. Oxford: Oxford University Press. 
because he was intent on explaining that the often confusing and multiple impressions of the senses did not reveal the unity of the universe, for which the concept of intelligible number provided him with helpful explanatory power in explaining unity and multiplicity. As this subject came to be of less urgency to Augustine's concern, he also lost some of his interest in the philosophy of number.

\section{Notes}

1 Solignac 1958 discusses some possible sources for Augustine's philosophy of number, highlighting the works of Nicomachus of Gerasa, whose Introductio arithmetica had been translated into Latin by Apuleius.

2 This is the argument in Augustine, Lib. arb. 2.

3 Horn 1994: 389-390.

4 Augustine, Conf. 4.13.20-4.15.27.

5 See for example Pseudo-Plutarch, De Homero 2.145.

6 Augustine, De ordine 1.2.3. Solignac 1957: 462-463 proposes Enn. VI.9.8 and VI.5.5 as sources.

7 For a wider discussion on happiness in Augustine, I refer to Ekenberg's chapter in this volume.

8 Augustine, Ep. 3.2; Schaff 1995: 221.

9 The aesthetics of Augustine has been covered in a number of scholarly studies, for example in Fontanier 2008.

10 Augustine, De musica 6.14 .44 offers a powerful expression of this insight.

11 Augustine, De ordine 2.18.47-2.19.51.

12 While the issue is contested in scholarship, Hadot 2005 gives a convincing argument in favour of a Neoplatonic background for the encyclopaedic project.

13 Horn 1994: 407-414 provides an overview of texts in which Augustine considers number after 391 .

14 The date of composition for De libero arbitrio 2 is disputed. See du Roy 1966: 236238 for a discussion on the different dates of Augustine's editorial work on the book.

15 For a comprehensive analysis of the philosophy of mind in De libero arbitrio 2, see O'Daly 1987.

16 On the modifications of the ascents by degrees in Augustine's career as a writer, see van Fleteren 1974.

17 Augustine, Lib. arb. 2.11.30; King 2010: 54-55.

18 Augustine, Conf. 7.17.23.

19 This question is thoroughly discussed in Dobell 2009: 183-198.

\section{Bibliography}

\section{Primary sources}

\section{a. Editions}

Green, William M. (ed.) (1970). Sancti Augustini De ordine libri duo. CCSL. Vol. 29. Turnhout: Brepols.

Jacobsson, Martin (ed.) (2002). Augustine, De musica liber VI. Stockholm: Almqvist \& Wiksell International.

Kindstrand, Jan Fredrik (ed.) (1990). Plutarchi De Homero. Leipzig: Teubner.

Verheijen, Luc (ed.) (1981). Sancti Aurelii Augustini libri XIII. CCSL. Vol. 27. Turnhout: Brepols. 


\section{Lars Fredrik Janby}

\section{b. Translations}

King, Peter (trans.) (2010). On the Free Choice of the Will, on Grace and Free Choice, and Other Writings. Cambridge: Cambridge University Press.

Schaff, Philip (trans.) (1995). Nicene and Post-Nicene Fathers. Vol. 1. Peabody, MA: Hendrickson Publishers.

\section{Scholarly literature}

Dobell, Brian (2009). Augustine's Intellectual Conversion: The Journey from Platonism to Christianity. Cambridge: Cambridge University Press.

du Roy, Olivier (1966). L'intelligence de la foi en la Trinité selon saint Augustin: Genèse de sa theólogie trinitaire jusqu'en 391. Paris: Études Augustiniennes.

Fontanier, Jean-Michel (2008). La beauté selon saint Augustin. Rennes: Presses Universitaires de Rennes.

Hadot, Ilsetraut (2005). Arts libéraux et philosophie dans la pensée antique: Contribution à l'histoire de l'éducation et de la culture dans l'antiquité. 2nd edition. Paris: J. Vrin.

Horn, Christoph (1994). “Augustins Philosophie der Zahlen.” Revue des Études Augustiniennes 40.2: 389-415.

O’Daly, Gerard J.P. (1987). Augustine's Philosophy of Mind. London: Duckworth.

Solignac, Aimé (1957). "Réminiscences plotiniennes et porphyriennes dans le début du 'De ordine' de Saint Augustin." Archives de philosophie 20.3: 446-465.

- (1958). "Doxographies et manuels chez S. Augustin.” Recherches Augustiniennes 1: $113-148$.

van Fleteren, Frederick (1974). "Augustine's Ascent of the Soul in Book VII of the Confessions: A Reconsideration.” Augustinian Studies 5: 29-72. 


\section{2}

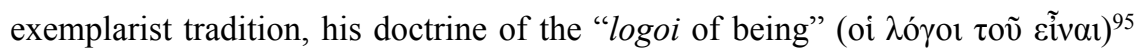
noting God to possess all the logoi of being prior to creation. Thus, despite Newman's suggestion that Platonism is to blame for Arius' errors, ${ }^{96}$ it has been demonstrated herein that it is not Platonism in toto, but a specific form of Platonism with a free-standing paradigm that can be traced to Arius - but this belief never became orthodox Platonism.

The similarity demonstrated in this chapter is borne out of two monotheistic "schools" of thought, each of which has a commitment to divine simplicity and each of which appeals to God as causa exemplaris in order to justify creation whilst still maintaining this commitment. From their shared monotheism, both orthodox Christianity and Platonism maintain that the archetype of creation is internal to the highest principle, not something over against the first principle: for a paradigm that is independent of the creative principle would result in a "practical polytheism." Accordingly, by embracing divine exemplarism in this manner, these two "schools" of thought are able to understand the cosmos as a living image of the divine. Not only this, but by standing firm in the claim that the world is made as a reflection of the highest principle, both "schools" are able to claim that this is the best possible world. Thus, this world of flux is bestowed intelligibility and order by being held ever present in the divine mind.

\section{Notes}

1 E.g. Beierwaltes 2014.

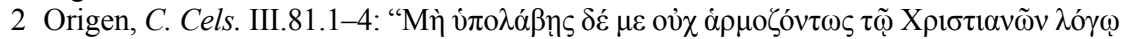

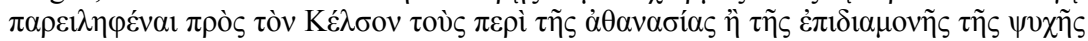

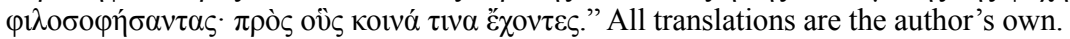

3 Augustine, Civ. Dei 8.5: "Si ergo Plato Dei huius imitatorem cognitorem amatorem dixit esse sapientem, cuius participatione sit beatus, quid opus est excutere ceteros? Nulli nobis quam isti propius accesserunt." Likewise, Simplicianus congratulates Augustine on reading the Platonists and not falling into the writings of other philosophers (cf. Augustine, Conf. VIII.2.3).

4 One can find the Christian Platonist agreement against materialism in Kenney 2016: 13. Also, Gerson makes the case for anti-materialism being a core tenet of Platonism in his account of 'Ur-Platonism', in Gerson 2017: 10-11.

5 Heb 2:6; cf. Ps 8:5 (LXX).

6 Mt 10:30; Lk 12:7.

7 Plotinus, Enn. IV.3.5, 10: $\grave{\varepsilon} \xi \varepsilon 1 \lambda \imath \gamma \mu \varepsilon ́ v \alpha 1$.

8 Plotinus, Enn. V.5.

9 Speusippus and Xenocrates maintained that the process described in the Timaeus was both timeless and eternal, pointing to a more allegorical and less wooden reading. Most Platonists, except for Plutarch and Atticus, followed this reading, see Dillon 1996: 7. For more on this, see also Meijering 1968: 140.

10 As noted by Zeyl in his introduction to his translation, Zeyl 1997: 1225.

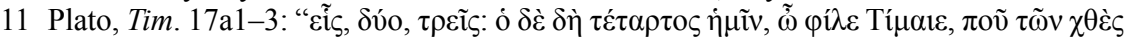

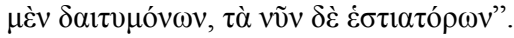

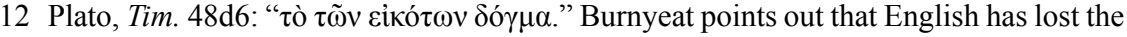
link between "likely" and "likeness" and that it would perhaps be better to choose an adjective such as "appropriate," "fitting," "fair," "natural," or "reasonable" as a transla-

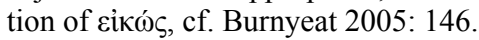

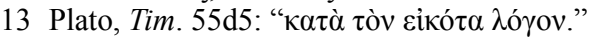


14 Burnyeat 2005: 155-156. Burnyeat also notes the thrust behind Timaeus' speech to be the rationality that underlies all creation: "I conclude that the exegesis Timaeus will offer is precisely an exegesis, explanation, exposition, or revelation of the rationality embodied by the Maker in the cosmos he produced"; also note "In the Timaeus the Creator is presented in a human way: he sees certain things, he wants, and he does certain things. The Timaeus is represented as a myth, therefore these expressions should not be taken literally, but it is at least significant that Plato, when the $\lambda$ ó $\gamma \circ \varsigma$ fails and he takes refuge in the $\mu \tilde{v} \theta 0 \varsigma$, uses these personal categories", Meijering 1968: 140.

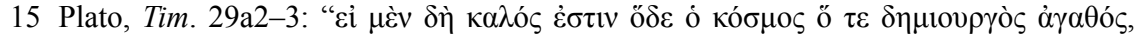

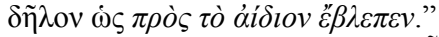

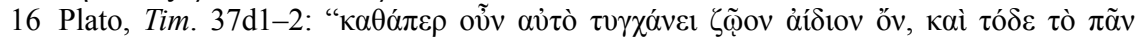

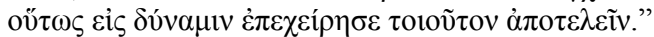

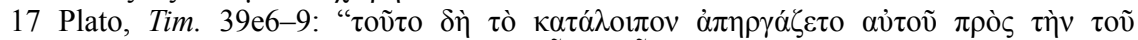

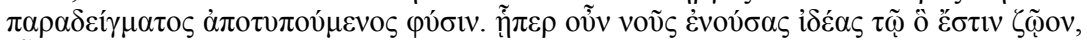

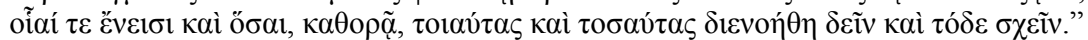

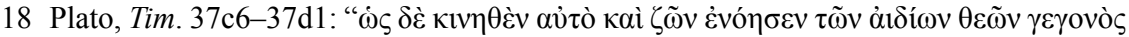

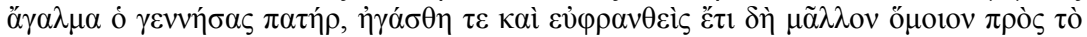

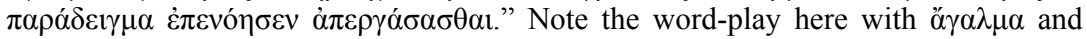
$\eta \gamma \gamma \alpha \dot{\sigma \theta \eta}$, the latter of these two coming from ö $\gamma \alpha \mu \alpha$.

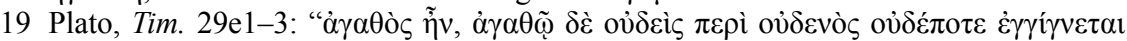

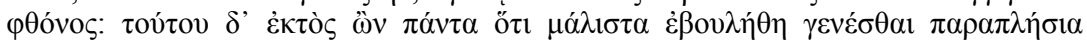
$\dot{\varepsilon} \alpha v \tau \tilde{\omega} . "$

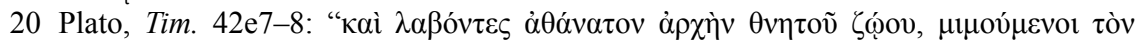

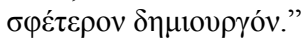

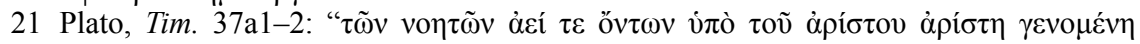

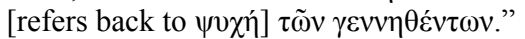

22 Plato, Tim. 37a.

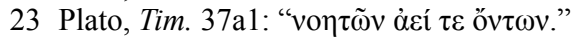

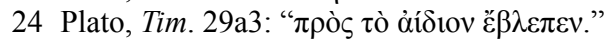

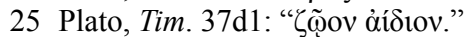

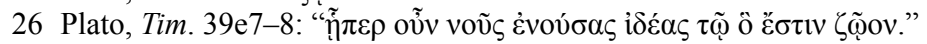

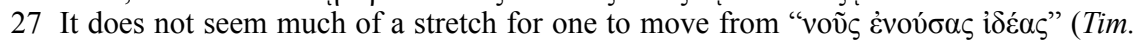

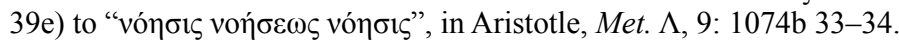

28 Aristotle, De anima III.4, 429a13-18.

29 Dillon 1996: 141.

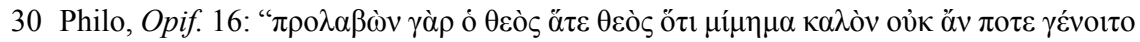

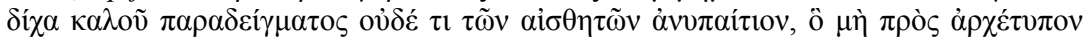

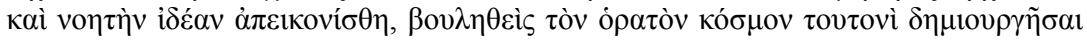

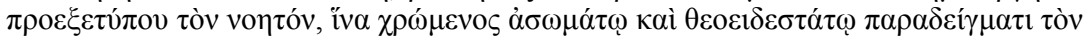

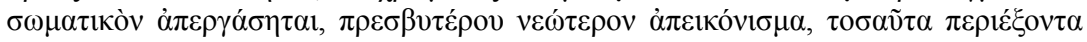

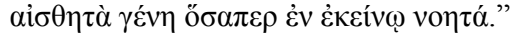

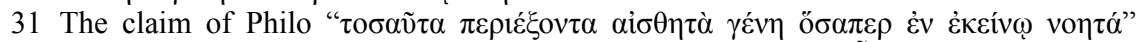

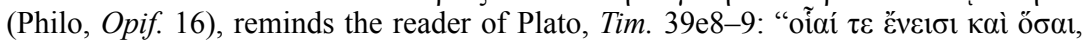

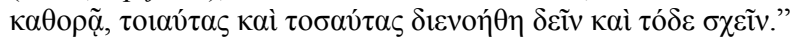

32 Louth 2007: 17.

33 Wolfson 1947: 193.

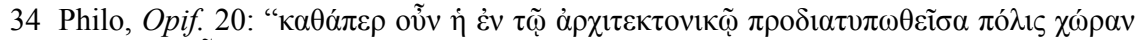

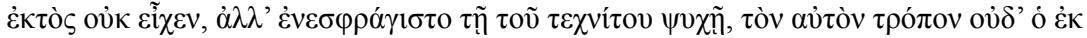

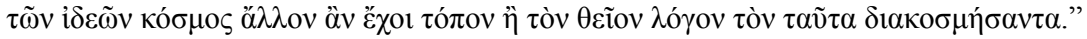

35 Philo, Opif. 6.25; Philo, Migr. 18.103; Cf. Wolfson 1947: 204 and 233; this mind is also the basis of the human mind, cf. Philo, Opif. 69.

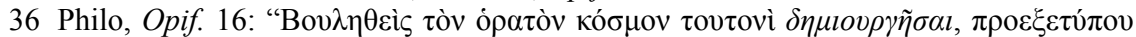

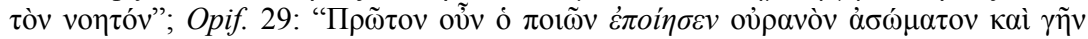

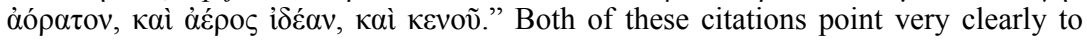
God's creation of the intelligible world. 
37 Cf. Dillon 1996: 367; "Even those Platonists who do not adopt a distinction between two gods (Supreme God and Demiurge), such as Philo, Plutarch or Atticus, make a strong distinction between God and his Logos, which amounts to very much the same thing."

38 Philo, Leg. All. III.33; Immut. 24.

39 Williams 1987: 122.

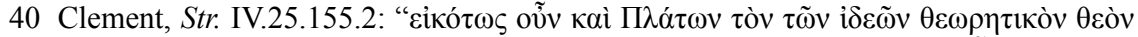

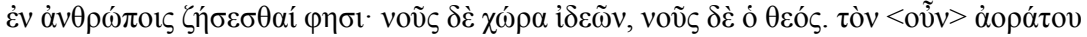

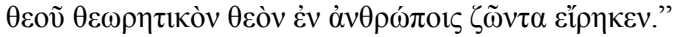

41 Clement, Str. V.14.39.3.

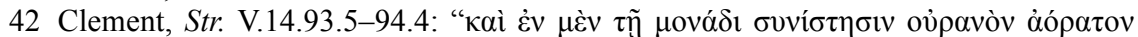

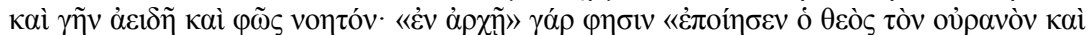

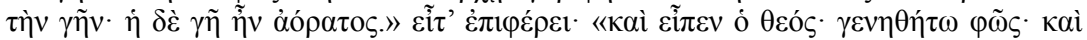

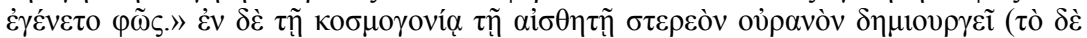

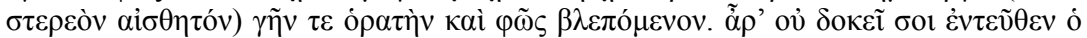

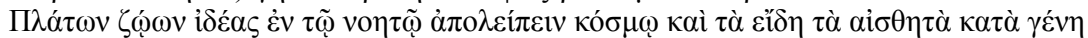

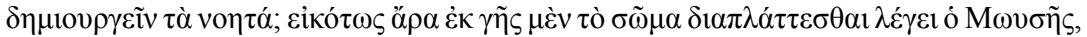

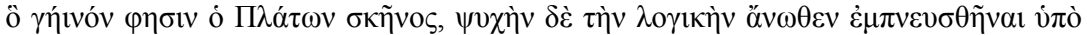

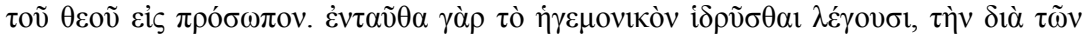

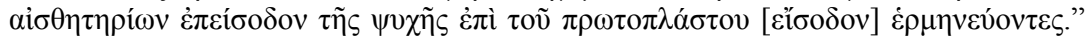
This translation assumes Clement's use of غ̇ $\pi \varepsilon i \sigma o \delta o v$ mentioned in the last sentence of this citation is resuming the theme of watchfulness ( addressed in the last sentence of the section immediately preceding it in the treatise. Here, by noting the interpretation of that which enters the soul, Clement appears to be resuming his theme of watchfulness in preparation for his next section, which is more clearly about anthropology, where he will tie image and likeness language from Genesis to $\lambda$ ó $\gamma_{0} \varsigma$ and voũ $\zeta$. Accordingly, this passage can be seen as doing a great deal of philosophical and anthropological work. Philosophically, Clement can be seen as using the divine mind as justification for the existence of human mind, a point made by Philo (Opif. 69). Anthropologically, Clement's appeal to the "first formed" seems to be a discussion of the inner-man, placing him squarely in line with Philo's account of double creation (Opif. 134). Origen, likewise, can be seen as an inheritor of this doctrine (Hom. in Gen. I.2; C. Cels. VI.63; Dial. Her. 11.19-20). Moreover, this paragraph makes very clear that the iं $\gamma \varepsilon \mu$ ovıкóv oversees that which enters one's soul, establishing it as a faculty that is concerned with the use of $\varphi \alpha v \tau \alpha \sigma i \alpha$. Thus, it appears that the $\dot{\eta} \gamma \varepsilon \mu$ ovikóv could be equated with the rational soul breathed into man by God;

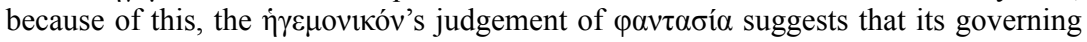
role extends to the soul's lowest capacities, granting rationality to the whole soul.

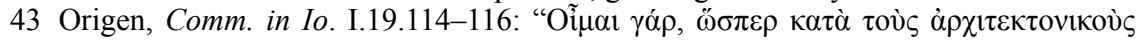

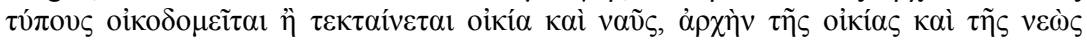

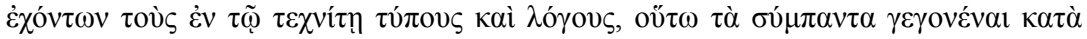

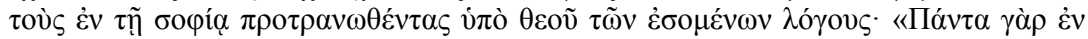

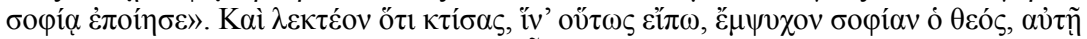

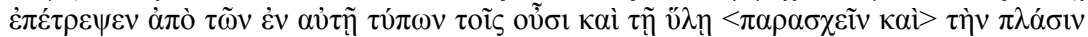

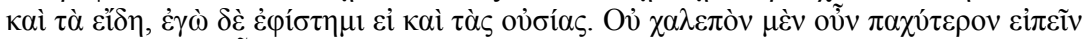

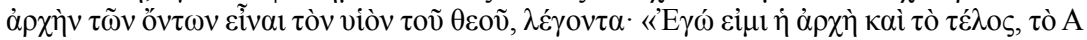

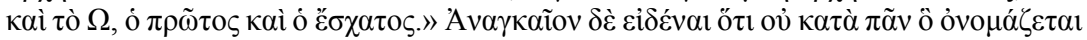

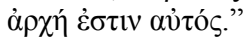

44 Origen, Hom. in Gen. 1.1; PG 12: 145c: "Non ergo hic temporale aliquod principium dicit: sed in principio, id est in Salvatore factum esse dicit coelum et terram, et omnia quae facta sunt."

45 Origen, Princ. I.2.2; PG 11: $131 \mathrm{~b}$.

46 John 17:14, 16.

47 Origen, Princ. II.3.6; PG 11: 195ab: "Cujus mundi difficilem nobis esse expositionem idcirco prædiximus, ne forte præbeatur aliquibus occasio illius intelligentiæ, qua putent 
nos imagines quasdam quas Graeci i $\delta \varepsilon ́ \alpha \varsigma$ nominant, affirmare: quod utique a nostris alienum est, mundem incorporeum dicere, in sola mentis phantasia vel cogitationum lubrico consistentem."

48 Origen, Princ. II.3.6; PG 11: 194b: "Quod enim Latine mundum dicimus, Graece

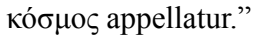

49 Crouzel and Simonetti 1978: 150, n. 30 (comment on Origen, Princ. II.3), are happy to follow Wolfson 1956: 270, who suggests that this assertion goes back to Origen and is not the hand of Rufinus. Crouzel and Simonetti note, "Le terme idea a été introduit en

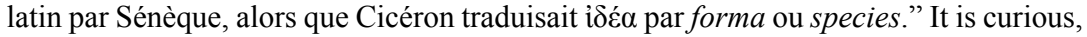
however, that imagines is the Latin used to translate i $\delta \varepsilon \dot{\varepsilon} \alpha$, as imagines can be taken as a direct translation, rather than an explanation. There is an understandable motive behind the desire to attribute this claim to Origen, as it would distance him from claims that he is simply a Platonist. Yet, it would appear that what is going on in this passage is not a denial of the divine ideas, but a particular understanding thereof. Moreover, it is not clear what the Greek would be behind this, if this is not taken as a Rufinian translation - is one seriously to believe that Origen is writing "the eikóves, which the Greeks call i $\delta \varepsilon \dot{\varepsilon}$, ," as most modern translations seem to suggest? Or, alternatively, were the underlying Greek $\varphi \alpha v \tau \alpha \sigma i \alpha \varsigma$, one would be right to raise the question as to why Rufinus did not translate such a term with phantasias here, when this appears to be what he does in the following sentence.

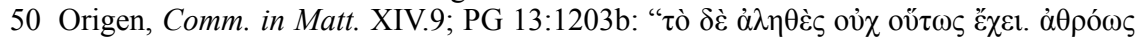

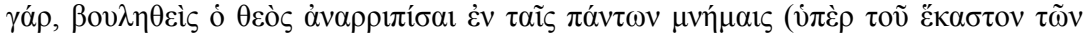

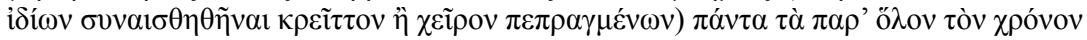

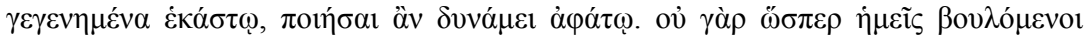

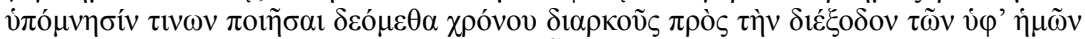

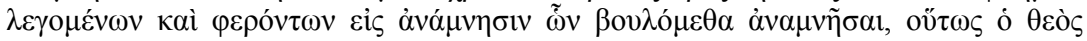

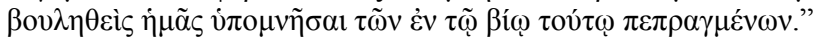

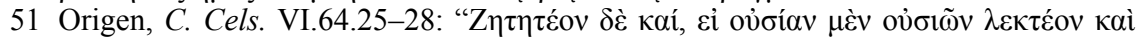

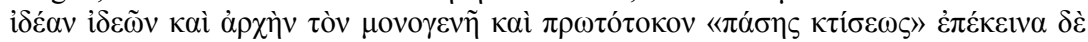

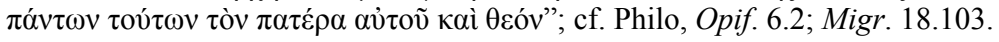

52 Origen, C. Cels. IV.54.11-16.

53 "If, as we have seen, the Demiurge - and the World Soul - are identified by Antiochus with the Stoic Pneuma-Logos, there is nothing left for the Paradigm of the Timaeus to be but the content of the intellect of the Logos, the sum-total of his logoi spermatikoi, on the pattern of which the physical world is constructed. Now by agreement among all later Platonists, the Paradigm of the Timaeus was nothing but the sum total of the Ideas, which are given no place as such in the Timeaus. The logoi spermatikoi of the Logos thus inevitably become for Antiochus the Ideas in their 'transcendent' or 'objective' aspect. A suitable home has been found for them; they may now be termed 'the thoughts of God'." Cf. Dillon 1996: 95.

54 Based on the fact that Proclus, too, holds a version of this position (In Tim. 232.21).

55 Proclus reports Plotinus' interlocutor, Longinus', belief that the Paradigm is posterior to the Demiurge (In Tim. 322.24), a position most likely developed in Longinus' "On First Principles," based on Porphyry's report, in Porphyry, Vit. Pl. XIV.18-20:

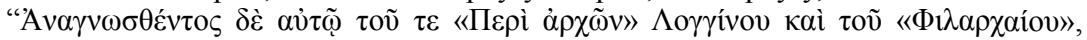

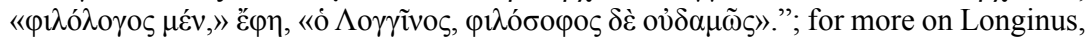
see Patillon and Brisson 2002.

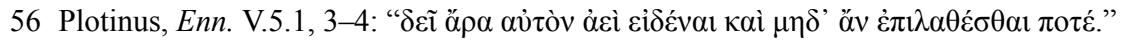

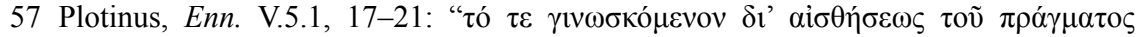

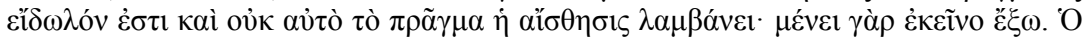

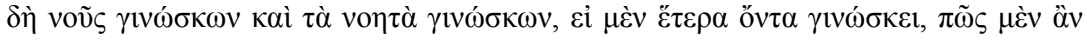

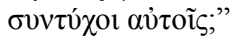

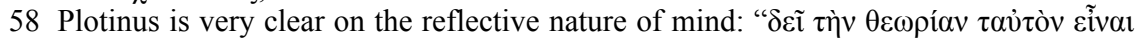

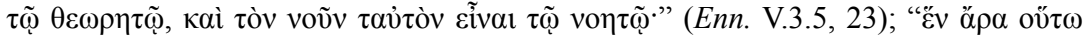




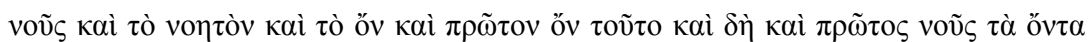

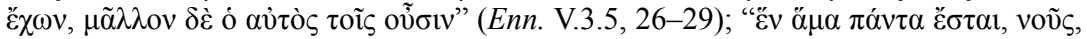

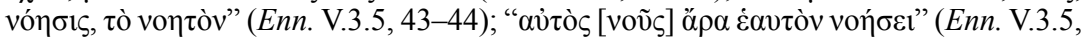

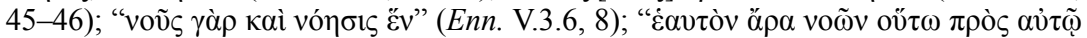

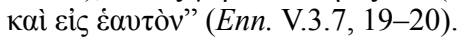

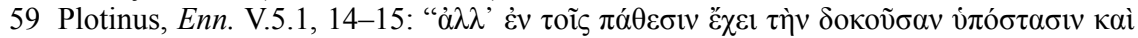

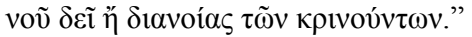

60 E.g. Plotinus, Enn. IV.3.5, 10.

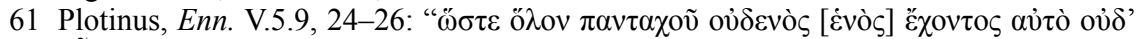

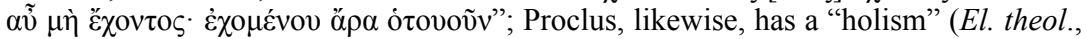
prop. 52).

62 This term is coined to express the way in which voṽ $\varsigma$ simultaneously thinks all things, cf. Emilsson 2007: 199-207. This notion ultimately means that there is no potency in the intellect: "all the intelligibles are fully whatever they are", cf. ibid.: 154.

63 See Enn. III.8 for a full explanation of the way in which contemplation grounds and is present in being; one might, likewise, consider Proclus' claim that that which is participated is present to its participant (El. theol. prop. 81).

64 Plotinus, Enn. III.2.1.21-22.

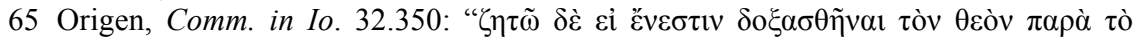

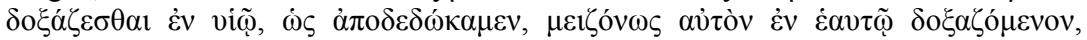

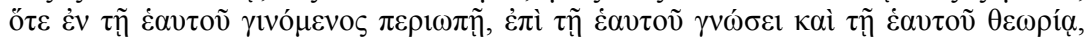

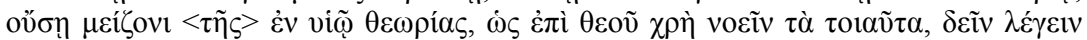

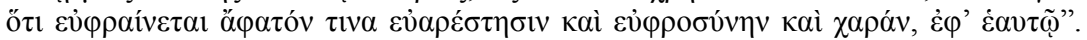
$\tau o t \alpha \tilde{v} \tau \alpha$ in the second to last clause is being taken adverbally; compare with Heine who translates, "because we must think such things in the case of God," cf. Heine 1993: 408.

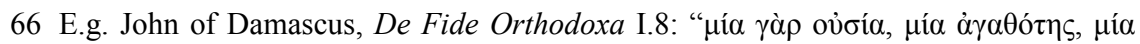

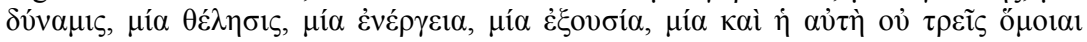

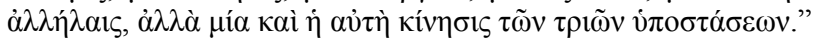

67 Stead notes that there is a substantial difference between Father and Son when he notes that, in Platonic fashion, Origen holds the Son as the one-many to the Father's status as one, cf. Stead 1977: 107. Also, consider what Stead says elsewhere, when he notes that, “Origen takes John 14:6, 'I am . . . the truth' as a basis for entitling Jesus $\dot{\eta} \tau \tilde{\eta} \varsigma$

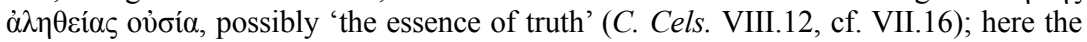
Son, as truth, is contrasted with the Father of truth; and 'truth' no doubt has its rather specialised Platonic sense of ideal and eternal reality (. . .). In another passage Origen suggests that the Son may be compared, not to the Idea of truth, but to the Idea of the Good itself, which is the source of the being and value of all the other Ideas; while the Father is still further exalted." Cf. Stead 1977: 152.

68 Origen, Comm. in Io. 20.157.

69 Stead 1977: 152.

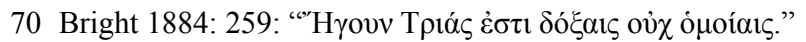

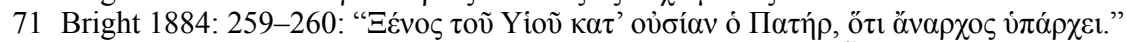

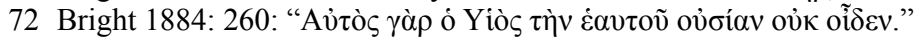

73 Williams 1987: 7; cf. Von Harnack 1901: 45.

74 Philo, Opif. 6.25; Migr. 18.103; Origen, C. Cels. VI.64.

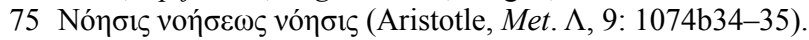

76 Williams 1987: 231.

77 Williams 1987: 7; cf. Von Harnack 1901: 40, especially 43.

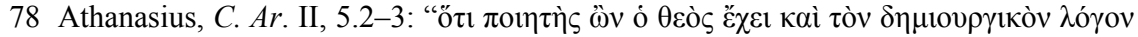

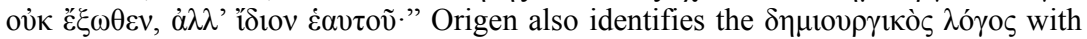
God's creative aspect; Origen, is, however, explicit that this Logos is the Son of God ( $\dot{o}$

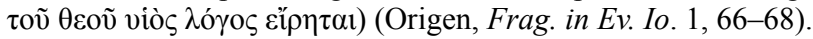


79 Anatolios Khaled gives a thorough treatment of this distinction in Khaled 1998: $100-109$. E.g. "the Son is 'proper to' (' $\delta 10 \varsigma)$ the Father, while all of creation is

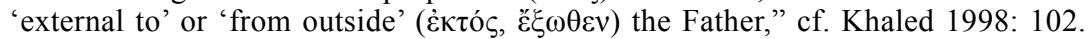
For other examples of this in Athanasius, see C. Ar. I, 15-16; C. Ar. II, 57; C. Ar. III, 1; C. Gent. 46-47.

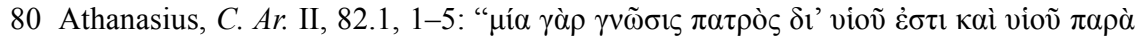

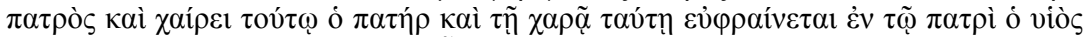

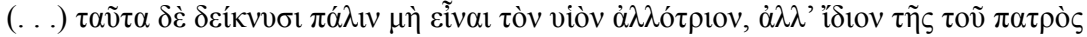

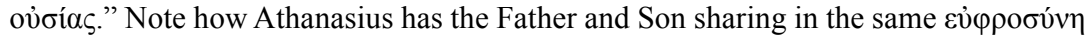

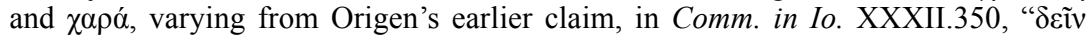

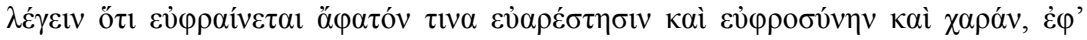
$\dot{\varepsilon} \alpha v \tau \tilde{\omega} . "$

81 John 1:14.

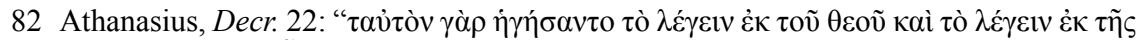

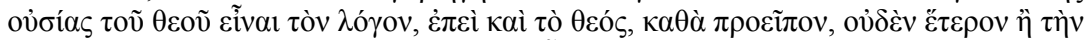

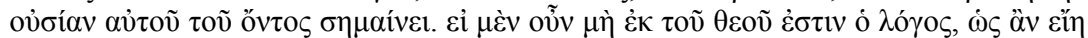

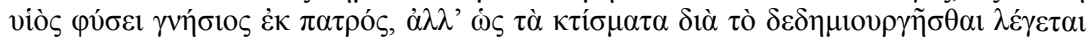

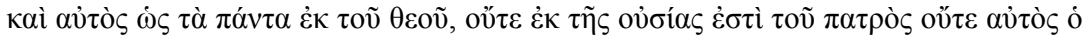

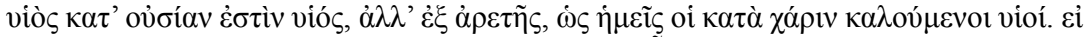

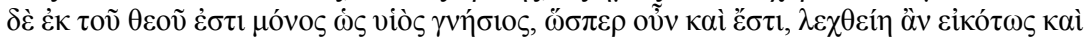

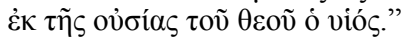

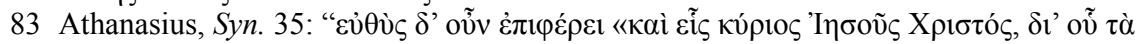

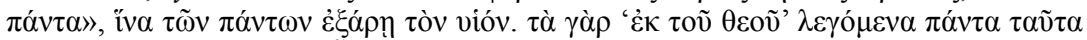

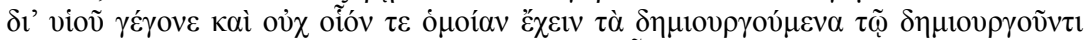

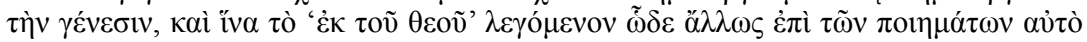

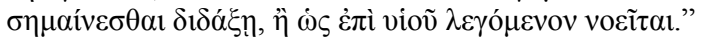

84 See n. 74.

85 Meijering 1968: 12.

86 Irenaeus, Adversus haereses II, 6.3; II, 3.1; II, 20.1; II, 20.2; IV, 34.1.

87 Irenaeus, Adversus haereses II, 42.2.

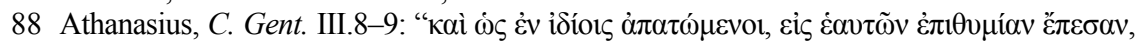

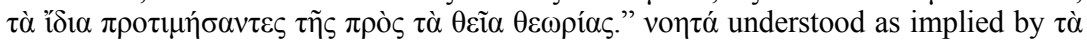
$\theta \varepsilon \tilde{\alpha} \alpha$, as it is used in this sense elsewhere in this passage.

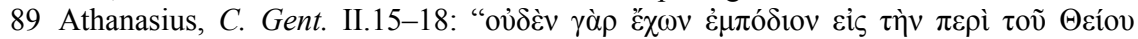

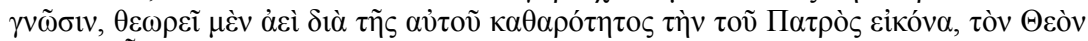

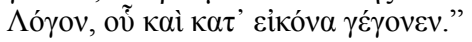

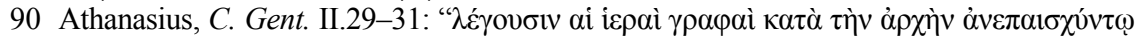

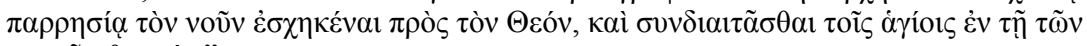

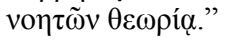

91 Origen, Princ. II.8.2-4.

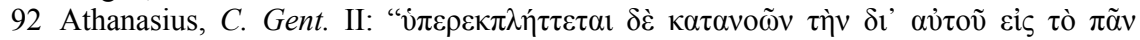

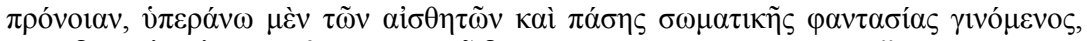

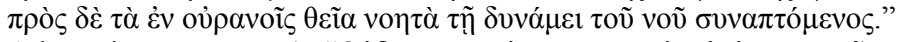

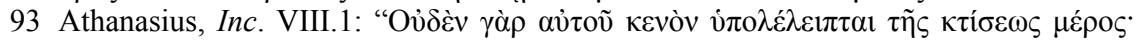

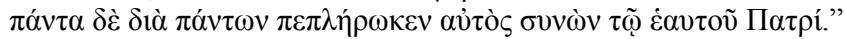

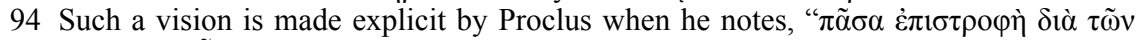

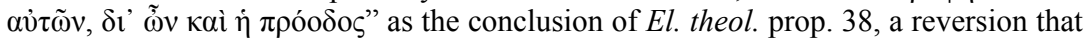
is only made possible on the basis of likeness to that to which the reversion is directed. In the above instance, in a manner similar to what Proclus will later establish, one's ability to discern such Logos-based providence is instigated by one's being made after the image of the Logos (Athanasius, C. Gent. II).

95 Maximus, Amb. Io. 7; for more see Tollefsen 2008: 21 and Törönen 2007: 128.

96 Newman 1871: 6. 


\section{Bibliography}

\section{Primary sources}

\section{a. Editions}

Armstrong, Arthur Hilary (ed. and trans.) (1966). "Porphyry, Vita Plotini." In Plotinus, Enneads. LCL. Vol. 1. Cambridge, MA: Harvard University Press.

Blanc, Cécile (ed.) (1966-1992). Origène, Commentaire sur saint Jean. SC 120-157-222290-385. Paris: Le Cerf.

Borret, Marcel (ed. and trans.) (2005). Origène, Contre Celse. SC 132-136-147-150. Paris: Le Cerf.

Bright, William (ed.) (1884). Athanasius, the Orations of St. Athanasius against the Arians According to the Benedictine Text. Oxford: Clarendon Press.

Burnet, James (ed.) (1902/1968). Platonis Opera. Vol. 4. Oxford: Clarendon Press.

Cohn, Leopold (ed.) (1896/1962a). "Philo of Alexandria, De Opificio Mundi." In Philonis Alexandrini opera quae supersunt. Vol. 1, 1-60. Berlin: Reimer/De Gruyter.

— (ed.) (1896/1962b). "Philo of Alexandria, Legum allegoriarum libri i-iii.” In Philonis Alexandrini opera quae supersunt. Vol. 1, 61-169. Berlin: Reimer/De Gruyter.

Crouzel, Henri and Manlio Simonetti (eds. and trans.) (1978-1984). Origène, De principiis. SC 252-253-268-269-312. Paris: Le Cerf.

Diehl, Ernst (ed.) (1903-1906). Procli Diadochi In Platonis Timaeum Commentaria. 3 Vols. Leipzig: Teubner.

Dodds, Eric R. (ed.) (1963). Proclus, Elements of Theology. Oxford: Clarendon Press.

Früchtel, Ludwig and Ursula Treu (eds.) (1985). Clement of Alexandria, Clemens Alexandrinus, Stromata. Band 2, Buch I-VI. GCS 52. Berlin/Boston: De Gruyter.

Harvey, William Wigan (ed.) (1857). Irenaeus, Sancti Irenaei episcopi Lugdunensis libri quinque adversus haereses. Vol. 1. Cantabrigiae: Typis Academicis.

Henry, Paul and Hans-Rudolf Schwyzer (eds.) (1964). Plotini Opera (editio minor). Vols. 1-3. Oxford: Clarendon Press.

Migne, Jacques-Paul (ed.) (1857-1886a). John Damascene, De Fide Orthodoxa. PG. Vol. 94, 790-1226. Paris: Imprimerie Catholique.

(ed.) (1857-1886b). Maximus the Confessor, Ambigua to John 7. PG. Vol. 91, 1092-1110. Paris: Imprimerie Catholique.

(ed.) (1857-1886c). Origen, Commentary on Matthew. PG. Vol. 13, 829-1800. Paris: Imprimerie Catholique.

(ed.) (1857-1886d). Origen, Homilies on Genesis. PG. Vol. 12, 145-280. Paris: Imprimerie Catholique.

O’Donnell, James Joseph (ed.) (1992). Augustine, Confessions. Vol. 1. Oxford: Clarendon Press.

Opitz, Hans Georg (ed.) (1940a). Athanasius, 'De decretis Nicaenae synodi'. Athanasius Werke. Vol. 2.1. Berlin: De Gruyter.

(ed.) (1940b). Athanasius, De synodis Arimini in Italia et Seleuciae in Isauria. Athanasius Werke. Vol. 2.1. Berlin: De Gruyter.

Preuschen, Erwin (ed.) (1903). Origenes, 'Fragmenta in evangelium Joannis (in catenis)', Origenes Werke. GCS 10. Vol. 4, 483-574. Leipzig: Hinrichs.

Ross, William D. (ed.) (1928). Aristotle, Metaphysica. Oxford: Clarendon Press. (ed.) (1961/1967). Aristotle, De anima. Oxford: Clarendon Press. 
Rousseau, Adelin, Bertrand Hemmerdinger, Louis Doutreleau and Charles Mercier (eds. and trans.) (1965). Irénée de Lyon, Contre les hérésies. SC 100. Livre 4. Vol. 2. Paris: Le Cerf.

Scherer, Jean (ed.) (1960). Entretien d'Origène avec Héraclide. Sources Chrétiennes 67. Paris: Le Cerf.

Thomson, Robert W. (ed. and trans.) (1971). Athanasius, Contra Gentes and De Incarnatione. Oxford: Clarendon Press.

Wendland, Paul (ed.) (1897/1962a). "Philo of Alexandria, De Migratione Abrahami." In Philonis Alexandrini opera quae supersunt. Vol. 2, 268-314. Berlin: Reimer/De Gruyter. _ (ed.) (1897/1962b). "Philo of Alexandria, Quod Deus sit Immutabilis." In Philonis Alexandrini opera quae supersunt. Vol. 2, 56-94. Berlin: Reimer/De Gruyter.

Wiesen, David S. (ed.) (1968). Augustine, the City of God against the Pagans: In Seven Volumes. LCL. Vol. 3. Cambridge, MA: Harvard University Press.

\section{b. Translations}

Heine, Ronald E. (trans.) (1993). Origen, Commentary on the Gospel According to John: Books 13-32. Washington, DC: Catholic University of America Press.

\section{Scholarly literature}

Beierwaltes, Werner (2014). Platonismus im Christentum. Frankfurt am Main: Klostermann.

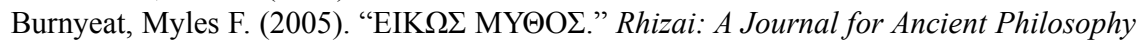
and Science 2.1: 143-165.

Crouzel, Henri and Manlio Simonetti (1978). Traité Des Principes. Tome 2. Paris: Le Cerf. Dillon, John M. (1996). The Middle Platonists: A Study of Platonism, 80 B.C. to A.D. 220. London: Duckworth.

Emilsson, Eyjólfur Kjalar (2007). Plotinus on Intellect. Oxford: Clarendon Press.

Gerson, Lloyd P. (2017). From Plato to Platonism. Ithaca: Cornell University Press.

Kenney, John P. (2016). "None Come Closer to Us Than These': Augustine and the Platonists." Religions 7.9, 114: 1-16.

Khaled, Anatolios (1998). Athanasius: The Coherence of His Thought. London: Routledge.

Louth, Andrew (2007). The Origins of the Christian Mystical Tradition: From Plato to Denys. Oxford: Oxford University Press.

Meijering, Eginhard P. (1968). Orthodoxy and Platonism in Athanasius: Synthesis or Antithesis? Leiden: Brill.

Newman, John Henry (1871). The Arians of the Fourth Century. 3rd edition. London: E. Lumley.

Patillon, Michel and Luc Brisson (eds.) (2002). Longin, Fragments - Rufus, Art Rhétorique. Paris: Les Belles Letters.

Stead, Christopher (1977). Divine Substance. Oxford: Oxford University Press.

Tollefsen, Torstein Theodor (2008). The Christocentric Cosmology of St Maximus the Confessor. Oxford: Oxford University Press.

Törönen, Melchisedec (2007). Union and Distinction in the Thought of St Maximus the Confessor. Oxford: Oxford University Press.

Von Harnack, Adolf (1901). History of Dogma. Vol. 3, trans. Neil Buchanan. Boston: Little, Brown and Co. 


\section{Daniel J. Tolan}

Williams, Rowan (1987). Arius: Heresy and Tradition. Cambridge, UK: Eerdmans.

Wolfson, Harry Austryn (1947). Philo: Foundations of Religious Philosophy in Judaism, Christianity, and Islam. Cambridge, MA: Harvard University Press.

(1956). The Philosophy of the Church Fathers. Cambridge, MA: Harvard University Press.

Zeyl, Donald J. (1997). "Introduction to Timaeus.” In Plato Complete Works, ed. John M. Cooper and Douglas S. Hutchinson. Indianapolis: Hackett Publishing Co. 
universe, and the natural cosmos indeed, is a dynamic universe in movement towards an infinite reality that is theurgically established and constantly fulfilled. Thus, nature and all material and natural symbols are not merely synthēmata to be intellectually conceived in order to facilitate a certain change of the psychological status; they are imprints of an ongoing ontological innovation and enrichment of the entire creation, of all particulars and universals. Dionysian theurgy aims precisely at the salvation of man and the entire creation. As such, it has "no parallel in the theurgy of Proclus or Late Neoplatonism in general." 122 This novelty certainly goes far beyond the (humanly governed) institutional capacities of any Church. ${ }^{123}$ Besides, one should not forget that it was precisely the "institutional church" of those times that rejected and crucified Him Who is the source of the Church, the source of Dionysian theurgy.

\section{Notes}

1 Parts of this chapter were initially prepared for the International Workshop Dionysius Areopagita Christianus: Approaches to the Reception and Reconstruction of the Christian "Tradition" in the Areopagitic Writings, at the University of Athens (February 2017). An improved and enriched version was presented at the 15th Annual Conference of the International Society for Neoplatonic Studies, in Olomouc, Czech Republic (June 2017). I wish to thank the organisers of the Workshop in Athens, Georgios Arabatzis and Dimitrios Pallis, for the invitation. My gratitude extends in particular to John Finamore and the ISNS Conference Committee for accepting the final paper and offering a grant for its presentation. Lloyd P. Gerson commented on an earlier version of the chapter. With Dylan Burns and Crystal Addey we had fruitful discussions during the ISNS Conference. Dimitrios A. Vasilakis and Christian Bull offered me several valuable insights. The series editors, Mark Edwards and Lewis Ayres, supplied me with substantial comments. I am grateful to all of them. Finally, I wish to particularly express my gratitude to my co-editors and supervisors of my doctoral dissertation, Torstein Theodor Tollefsen and Eyjólfur Kjalar Emilsson, for their encouragement, continuous inspireful support and friendship, and to Lars Fredrik Janby for our intensive collaboration.

2 Dionysius, EH I.1; PG 3: 372a.

3 Cf. Vanneste 1959; Saffrey 1966; Saffrey 1982; Sorabji 1990; Shaw 1999; Dillon 2014. See also the famous dictum of Anders Nygren (Agape and Eros) who built upon Martin Luther and said about the Areopagite that "the fundamental Neoplatonism is but scantily covered with an exceedingly thin Christian veneer." For this quotation from Nygren and other interesting remarks on his view of Dionysius as "platonising" rather than "christianising," see Golitzin 1999: 131-133.

4 Indeed, the literature is growing. I simply refer, in a comparative mode, to the overall placement of Dionysian studies with regards to the sum of studies on Neoplatonism.

5 For instance, Dillon 2014: 111-112. For a collection of central studies on this issue, see Burns 2004: 111, n. 1. To my knowledge, the most recent work focusing on theurgy in the pagan world is the detailed study of Crystal Addey Divination and Theurgy in Neoplatonism: Oracles of the Gods, cf. Addey 2014, which contains a rich bibliography on Neoplatonic theurgy.

6 Burns holds the view that "it is only by examining Proclus' practice beyond his treatises, in their sociohistorical context, that Pseudo-Dionysius' reasons for changing the Iamblicho-Proclean theurgic model become clear," cf. Burns 2004: 113.

7 Sorabji 1990: 11-12.

8 This reflects Shaw's conclusive argument, in Shaw 1999: 598-599. 
9 Andrew Louth has made some very clear points with regard to Dionysius' originality in relation to Neoplatonism, in Louth 1989: 84-87. See also Florovsky 1987: 204-229 and Golitzin 1999. Vasilakis espouses this view in his chapter On the Meaning of Hierarchy in Dionysius the Areopagite, in the present volume.

10 Dionysius, Ep. 9.1, Heil and Ritter 1991: 198.3-5; PG 3: 1108a. This is nothing other than the Last Supper offered by Christ to His disciples, shortly before the betrayal and the Passion.

11 Dionysius, Ep. 4, Heil and Ritter 1991: 161.5-10; PG 3: 1072c.

12 This has been noticed by the Dionysian scholarship more than a century ago, with the studies of Hugo Koch and Josef Stiglmayr, cf. Perczel 2000: 491. See also, Louth 1986: 432; Louth 1989: 81; Golitzin 1999: 133-134, and Dillon 2014: 112.

13 John Rist has something interesting to say about how Dionysius uses Neoplatonic language in a different conceptual orientation, in Rist 2010: 245-246.

14 Vladimir Lossky moves even further, when he notes that "we must not imagine that Christian and pagans lived in water-tight compartments, especially in Alexandria where both participated in the same culture, in the same intellectual life," cf. Lossky 1983: 67. Lossky regards the community of language and the common methodology as two aspects of the natural kinship of the same cultural tradition shared by both the pagan and Christian contemplatives of Alexandria (ibid.: 68). So, by speaking of "different orientation of the use of a common language," I refer to what Lossky points out as "different religious frameworks of the same thems of Hellenistic spirituality," (cf. ibid.: 67).

15 Cf. ibid.: 121-122.

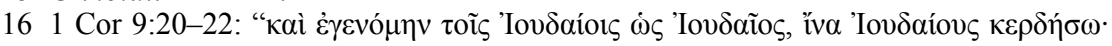

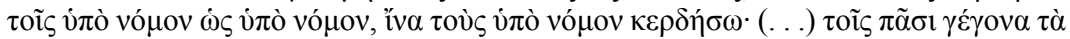

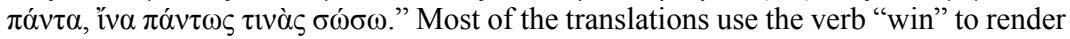

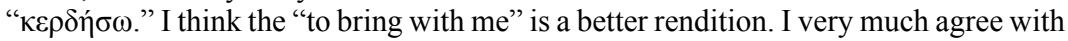
Dimitrios A. Vasilakis, who comments, in this respect of the relation of the unknown author of the $C D$ with St Paul that "historical fiction is different to spiritual indebtedness." Cf. Vasilakis' chapter in this volume, n. 44.

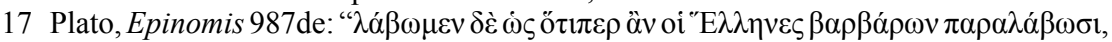

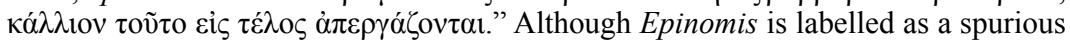
work (Diogenes Laertius (Plato, III.37, and 46) registers that some people say that the author of the Epinomis was Plato's disciple Philippus of Opus). In any case, I find this passage perfectly illustrating Plato's own method and practice.

18 I personally prefer such an interpretative possibility for a productive synthesis in Dionysius; it goes beyond a rather superficial view and "comparison" of the Christian and Platonist tradition in terms of superiority of the former, as asserted in Wear and Dillon 2007: 12. Besides, this attitude is not exclusively Dionysian. It is already present in the thought and the works of St Basil the Great.

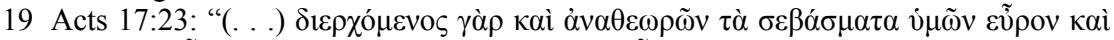

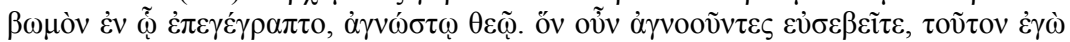

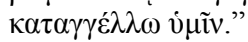

20 Cf. Dionysius, CH IV.1, Heil and Ritter 1991: 20.9-11; PG 3: 177c. Although one might have wished to have a more explicit statement by Dionysius on the creatio ex nihilo of the cosmos, I think it is safe to admit that, even in an implicit manner, the Areopagite adheres to the creation of the cosmos by God out of nothing. Louth (1989: 85), notes that Dionysius "never speaks of creation ex nihilo, even though by this time the idea of creation out of nothing had become the normal and accepted way in which Christians expressed their belief in creation." For the possibility of maintaining a creationist view within the phenomenally emanationist Neoplatonic setting in the Areopagite's works, see Damian 2011: 96-97. On the possibility of taking $\pi \alpha \rho \alpha \gamma \omega \gamma \eta$ in Dionysius as implying creation out of nothing, see Golitzin 2013: 105-113. For an inquiry into a Christian orthodox doctrine of 
creation in the Areopagite, see Tollefsen 2008: $113 \mathrm{ff}$. The reader would greatly benefit from Tollefsen's chapter on Proclus, Philoponus, and Maximus: The Paradigm of the World and Temporal Beginning, in this volume, where Tollefsen compares Neoplatonic and Christian doctrines of creation. Following his argument that "the classical Christian doctrine of creation reached its completion in major thinkers of the fourth century," it is plausible to claim, I think, that the Areopagite could but have adhered to this doctrine, as well. This claim could also be supported by Brown Dewhurst's chapter in the present, where she argues for fundamental divergences between Proclus and St Maximus the Confessor in their views on the origin of the cosmos. The given agreement of Dionysius with St Maximus on the existence of one Triune God who creates without the aid of intermediate deities would be enough to conclude that the Areopagite adheres to creation rather, than to emanation. See also, infra n. 121.

21 Rorem admits, though, that the similarities between Iamblichus and Dionysius do not necessarily mean that the Areopagite read De Mysteriis. Cf. Burns 2004: 112.

22 Louth 1986: 432.

23 Struck 2001: 25-26. One could, for instance, think of St Gregory of Nyssa, who in many regards has been much influential to Dionysius, cf. Golitzin 1999: 136 and Florovsky 1987: 213. But as the Lexicon Gregorianum shows, there is no use of the term $\theta \varepsilon o v \rho \gamma i$ í by Gregory. However the case may be, I would agree with Rorem's conclusion that "Dionysius' ritual theory must be understood 'in general (. . .) in the context of basically patristic precedents'." Cf. Struck 2001: 26.

24 Cf. Burns 2004: 121.

25 Dillon 1973: 29.

26 Rorem 1984.

27 Shaw 1999: 582. The tripartite division of mankind and souls is also present in preIamblichean traditions, such as Valentinians, Sethians and Hermetists. Dylan Burns has summed up the arguments of Rorem and Shaw about the aspects of Iamblichean theurgy that, according to them, are replicated by Dionysius, cf. Burns 2004: 112.

28 Note, for instance, the divergences between Proclus and Plotinus on the question of matter as badness, as it is specially treated in Emilsson's chapter Plotinus' Doctrine of Badness as Matter in Ennead I.8., in this volume.

29 See passage $\mathrm{T} 2$ below.

30 Burns has some useful notes about the tendency of comparing Dionysius with Iamblichus, and not Proclus, on theurgy, in Burns 2004: 113 and n. 9. It would also be fruitful to explore other possible reasons for a closer relation of Dionysius to Iamblichus rather than to Plotinus, in the perspective of what Chlup calls Iamblichean 'eastern' Neoplatonism, cf. Chlup 2012: 18, that flourished in the 4th century Syria.

31 Louth 1986: 434.

32 See, for instance, De Myst. III.11, 125.4-5; III.24-25, 157.12-14; III.27, 165.7-10; IV.8, 192.1-3; V.10, 210.11-12; X.3, 287.15-288.1; Clarke et al. 2003: 146-147, 178-179, 186-187, 214-216, 240-241, 346-347. See also Shaw 1999: 596, and Shaw 1995: 86-87. Crystal Addey notes that epitédeiotess in Iamblichus summons "the ritual, intellectual and ethical qualities which were considered to be essential for the theurgist to develop," and she argues that the term accounts for the difference

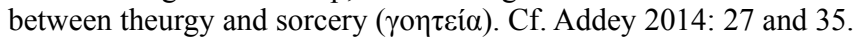

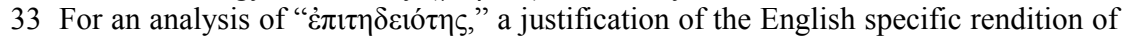
the term, and insights on "aptitude" in Late Antique and Early Christian thought, see Pavlos 2017a and 2017b.

34 Cf. Emilsson and Strange 2015: 28. See also Schroeder 2014, an excellent piece on the influence of Alexander to Plotinus; although it does not treat epitédeiotēs explicitly, the specific influence can be extracted as a corollary from Schroeder's analysis. 
35 I investigate this further in my doctoral dissertation, "The concept of Aptitude ('E $\left.\pi \imath \tau \eta \delta \varepsilon เ{ }^{\tau} \eta \varsigma\right)$ in Late Antique and Early Christian Thought," at the Department of Philosophy, University of Oslo. For sporadic but substantial remarks on epitédeiotess in the thought of St Maximus the Confessor, see Tollefsen 2008: $185 \mathrm{ff}$.

36 On epitēdeiotēs in a physical context, see Sambursky 1962: 104-109. For remarks on epitêdeiotês in Philoponus' cosmological account, see Tollefsen's chapter in this volume.

37 Plotinus, Enn. VI.4.11, 3-4; VI.4.15, 1-6; 12-13. Cf. Emilsson and Strange 2015: 26-28.

38 Rarely, however, Iamblichus employs the term as associated to an agent rather than a patient. Cf. Clarke et al. 2003: 217.

39 Sambursky 1962: 106.

40 Iamblichus, De Myst. III.11, 124.14-125.6; Clarke et al. 146-147.

41 I am basically commenting on the last sentence of passage T1, which I have added in Greek. It is however possible to discern the "normal" Plotinian influence on Iamblichus' understanding of epitédeiotēs, when Iamblichus refers to prayer. He asserts that prayer is effective in that it "enlarges very greatly our soul's receptivity to the gods, reveals to men the life of the gods, accustoms their eyes to the brightness of divine light, and gradually brings to perfection the capacity of our faculties for contact with the gods." Cf. Wear and Dillon 2007: 63. Here we have the original Plotinian motive of a certain (innate) potency that is supported "internally" - not through material items - by epitédeiotēs. This Iamblichean passage is interesting also because it illustrates the dynamic character of epitédeiotess that affects potency in two ways: it both leads it to actualisation and increases it.

42 Dionysius, Ep. 8.2, Heil and Ritter 1991: 180.12-16. Cf. Wear and Dillon 2007: 95. Interestingly, Iamblichus does not maintain the Plotinian picture that is apparently preserved by Dionysius when the latter asserts that there is an approximation with the divine not in spatial terms but according to the aptitude for receiving God. Plotinus originally illustrates this idea in Enn. VI.4.15.

43 Iamblichus, De Myst. V.23, 233.9-13; Clarke et al. 268-269.

44 Cf. Plotinus, Enn. II.9.

45 Dodds asserts that the term "theurgy" is not found anywhere in Plotinus' Enneads, cf. Coughlin 2006: 150. Louth (1986: 432) notes that, "Plotinus had no time for theurgy: the world $\theta \varepsilon o v \rho \gamma i \alpha$ is not used in the Enneads, he uses the older, derogatory word,

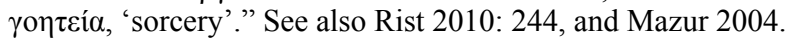

46 Cf. Clarke et al. 2003: 269. My understanding is that Iamblichus qualifies the aforementioned material objects as sacred, perfect and divine already before, and apart from, their specific theurgic composition and transformation into a receptacle.

47 Shaw 1999: 596.

48 Iamblichus, De Myst. V.18-19, 225.1-4; Clarke et al. 2003: 256-259.

49 The integration of theurgy in Proclean Neoplatonism is perhaps the most fruitful evidence to this. Cf. Van den Berg 2014: 261.

50 Indeed, it would be somewhat oversimplifying to pose a radical distinction between theory $(\theta \varepsilon \omega \rho i \alpha)$, or theology $\left(\theta \varepsilon \circ \lambda \circ \gamma^{i} \alpha\right)$ and theurgy. For Dionysius, who had seen theourgia as the consummation of theologia, this would have been impossible. This Iamblichean passage confirms Zeke Mazur, who argues that "theōria and theurgia are ambiguous categories that admit of some overlap." Thus, contemplation cannot be understood as simple intellection, just as theurgy does not merely designate external or material ritual practices, cf. Coughlin 2006: 151. At the same time, Iamblichus is well aware of the distinct roles of theology, theurgy and philosophy, when he promises that he shall provide explanations to Porphyry's attacks in a manner proper to the respective question, cf. Coughlin 2006: 151. 
51 Iamblichus, De Myst. VI.6, 246.12-247.2; Clarke et al. 2003: 286-287. I add the Greek text here because it bears similarities with a significant Dionysian extract we

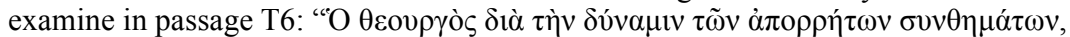

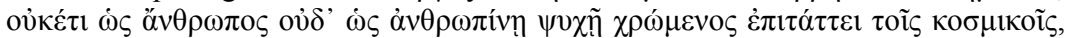

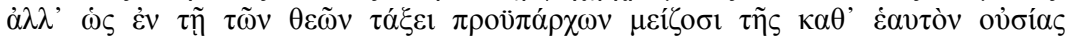

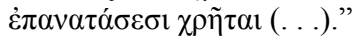

52 Needless to mention the enthusiasm I experienced when in my first reading of De Mysteriis I realised how much of pagan reality is preserved in the series of comics "Astérix," by René Goscinny and Albert Uderzo. There, the equivalent to the Colophonian oracle's water mentioned by Iamblichus in De Mysteriis, is the magic broth made by the druid with an arcane recipe that only he knows.

53 Two remarks here. The first is that such a being, perfect God and perfectly man, would sound to Iamblichean ears at least as strange as it would sound to Plotinus' the inclusion and identification of the absolute Universal, the One, to an absolute particular, a man, and this made of without the aid of any mystical ascent. Secondly, the reader should not think that I use - arbitrarily, one might say - the Council of Chalcedon as a means to heal what has been admitted by Georges Florovsky as "a certain vagueness of Dionysius' christological ideas," cf. Florovsky 1987: 225. Rather, I do wish to stress in this way the permanence of theurgic identity in Areopagite's theourgos against the temporality of theurgic properties in Iamblichus'.

54 Dionysius, EH III, Heil and Ritter 1991: 79.1-94.22. Cf. Louth 1989: 60.

55 Ibid.

56 Louth 1986: 434.

57 On the relation of this initial status of sacraments to the later tradition of the Church, see Louth 1989: 57-58.

58 Indicatively, see Florovsky 1987: 225.

59 Cf. for instance, Grillmeier and Hainthaler 2013: 311-342.

60 Dionysius, EH I.1, Heil and Ritter 1991: 63.12-64.4; PG 3: 372a; Parker 1897: 168.

61 Dionysian theology stems from the Scriptural truth that is tirelessly repeated throughout the Corpus. The Areopagite acknowledges one Triune God. In $E H$ he affirms the triadic in unity blessedness of the beyond all Godhead as the singular cause of beings, the source of life, the principle of hierarchy and the essence of

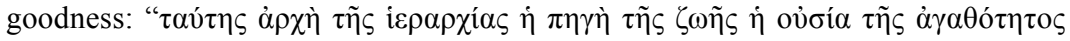

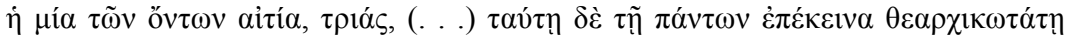

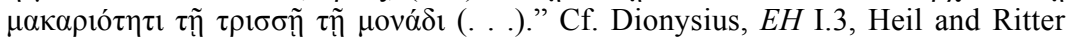
1991: 66.6-9; PG 3: 373cd.

62 Dionysius, Ep. 4, Heil and Ritter 1991: 161.5-10; PG 3: 1072bc; Parker 1897: 95:

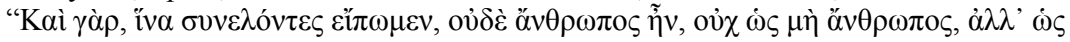

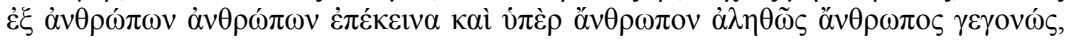

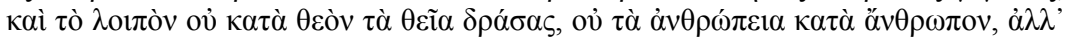

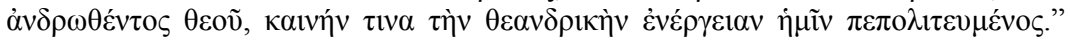
Note the dialectics of affirmations and negations with regard to the nature(s) of Christ, in this passage: they demonstrate an understanding of "theurgist" by the Areopagite radically contrasting the Iamblichean theurgist who "commands cosmic entities no longer as a human being or employing a human soul (. . .)", in passage T4.

63 Saffrey 1966: 98.

64 Dionysius, $C H$ IV, Heil and Ritter 1991: 22.25-23.5; PG 3: 181b; Parker 1897: 158.

65 Dionysius, EH III, $\theta \varepsilon \omega p i ́ \alpha$ 5, Heil and Ritter 1991: 84.18-21; PG 3: 432b. I use the translation of the passage made by Struck, in Struck 2001: 31. Notably, the term $\tau \varepsilon \lambda \varepsilon \sigma 10 v \rho \gamma i \alpha$ is employed by Iamblichus in several places in the De Mysteriis.

66 Louth 1986: 434. Louth's claim has been given a solid grounding after the work on Dionysian Christology by Grillmeier and Hainthaler 2013.

67 Florovsky 1987: 211. I am very grateful to fr. Johannes Johansen, rector of the Norwegian Orthodox Church of St Nicholas in Oslo and Christ's Transfiguration Parish 
in Rogaland, and to Torleif Thomas Grønnestad, for granting me access to the Stavanger Orthodox Library, whereby I borrowed a copy of the otherwise hardly accessible Collected Works of fr. Georges Florovsky.

68 I found the analysis of this subject in Emilsson 1999 very illuminating.

69 For the time being, I am happy to leave this claim in its present form without further justification.

70 See respective lemmas, in Nasta 2013: 3.

71 Florovsky 1987: 211.

72 See relevant remarks on "synergy" in Vasilakis' chapter in this volume, nn. 45 and 96.

73 Florovsky 1987: 216.

74 Ibid.

75 Dionysius, DN XI.5, Suchla 1990: 221.5-10; PG 3: 953a.

76 See also the section on Theourgia - Hierourgia (Chapter 7), in Wear and Dillon 2007: 99-115.

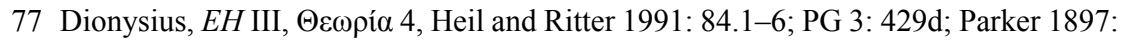
202.

78 Dionysius, Ep. 9.1, Heil and Ritter 1991: 198.3-5; PG 3: 1108a.

79 Gontikakis 1984: 61-62.

80 Ibid. A modern "theurgist" would also claim the same about the revival of Iamblichean theurgy nowadays. The difference lies on what exactly is acted.

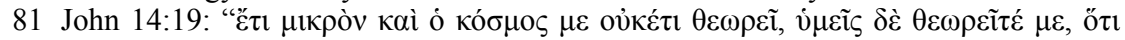

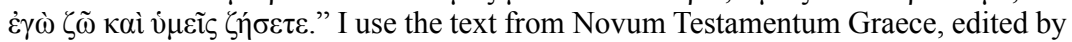
Nestle-Aland.

82 Louth 1986: 435.

83 I would partially agree with Burns, who argues that "when he [Dionysius] argues that 'theurgy is the consummation of theology,' he refers to a systems of ritual liturgics in which the priest not only needs to be saved through theurgic symbols, but needs to save others by using them properly, as prescribed." The terms "save others" and "using" that Burns employs, assign the Dionysian priest with a task that I do not think it is prescribed by the Areopagite. Cf. Burns 2004: 122 and n. 49.

84 Cf. Russell 2006: 258.

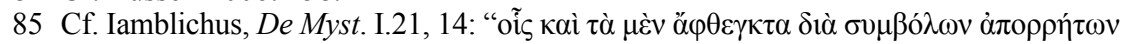

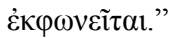

86 Wear and Dillon 2007: 102.

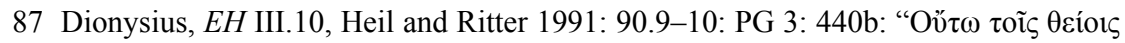

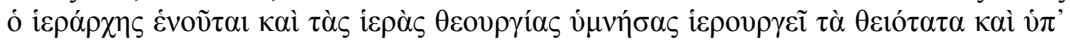

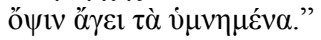

88 John Finamore notes further that, for Iamblichus, "the largest segment of humanity is held down by nature, is subject to fate, and never rises. Other human beings can and do make progress through theurgical ascent." Cf. Finamore 2014: 289. By "kata symbebēkos" I refer to the minority of humans identified above by Finamore.

89 Louth 1986: 434.

90 Cf. the excellent illustration of this cosmic freedom, in Florovsky 1987: 218.

91 One may reasonably think that, in such a cosmic setting, the Neoplatonic generalisation of Stoic sympatheia, that applies to the entire cosmos and opens room to Iamblichean theurgy, needs a radical revision.

92 Cf. Ivanovic 2017: 150.

93 It is a central conviction of the Areopagite, shared by St Maximus the Confessor as well, that synergy between God and man is the foundation for deification of the latter, cf. Ivanovic 2019: 210.

94 Shaw 1999: 589.

95 Ibid.: $587-590$.

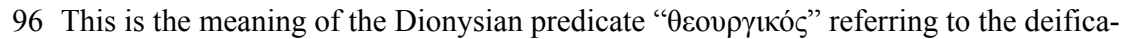
tion of the human being. See also Wear and Dillon 2007: 102. 
97 This does not contradict my previous claim that for Dionysius the only theurgist is Christ. For deification of the human being amounts to likeness to Christ in His complete Glory (as far as possible), a glimpse of which was offered to few disciples, the day of Transfiguration. And so long human beings become Christlike they become theurgists.

98 Shaw 1999: 595.

99 Ibid.: 573.

100 I very much suspect that apologetics are to be found on both sides of the river, both on the Neoplatonist and the Christian shore. In general, the apologetics, though often under attack, are neither bad people nor inaccurate with regard to the evidence. Socrates, for instance, was such a person, as Plato reminds us in his Apology of Socrates.

101 Shaw 1999: 595-596.

102 In the tendency of the literature to bring together Dionysius and Proclus (and Iamblichus) on theurgy, Christ is regarded as a Dionysian symbol, cf. Burns 2004: 125. But this raises the question whether Christ is a symbol, and, if yes, of what. For the Areopagite Christ is a being, perfect God and man. A symbol refers by definition to something beyond itself. But is there anything beyond, or apart from, Christ to be symbolised by Him? I think Dionysius' answer, as it comes out from his Corpus, is no. If that is the case, then Christ could be taken as a symbol only on the basis of being a symbol of Himself. But, then, are we not far way from Neoplatonism? Perhaps the reasons that prompt one to think of Christ as a symbol in a Neoplatonic manner, could be understood on the basis of the Dionysian method of paraphrasing respective passages from Proclus' Platonic Theology, in which the role of Jesus is analogous to that of Plato. But, again, these analogies hide fundamental divergences that lead me to the view I presented above. István Perczel's analysis is very fruitful and I shall only borrow one point to support my claim: "In other words, he [Jesus] is not only the principal Revelator as is Plato in Proclus' system, but also the Revealed and the Revelation itself." Cf. Perczel 2000: 501-502. Perczel concludes his comparative reading by noting that "instead of [Jesus] being a messenger of the higher beings [as Plato is], he [Jesus] is their principle", in ibid.

103 Shaw 1999: 595.

104 One may check the instances where the author of the $C D$ employs the term $\sigma \tilde{\omega} \mu \alpha$. But what I find sufficiently arguing for the Dionysian anticipation of the body's inclusion in deification - which also implies resurrection of the dead - is the eschatological passage from the $D N$ that connects deification with Christ's Transfiguration, in $D N$ I.4, Suchla 1990: 114.7-115.5; PG 3: 592c.

105 Shaw 1999: 595.

106 Ibid.: 596.

107 See n. 78 in Vasilakis' chapter in this volume, for details about the disputed label of the $E H$ treatise.

108 Florovsky 1987: 217.

109 See also Vasilakis' chapter in this volume and especially n. 24.

110 There is no passage in the $C D$ where Dionysius employs theurgy dissociated from Christ. Cf. Burns 2004: 125 and n. 66.

111 Armstrong 1973: 11.

112 Shaw 1999: 598.

113 Cf. Burns 2004: 127, who builds upon Shaw. The latter has a very interesting reference to St Maximus' the Confessor's Mystagogia, a work that, indeed, can be seen as a commentary on Dionysius' Ecclesiastical Hierarchy. There Maximus refers to the church as an "image of the sensible world" and he says that "the world can be thought of as a church," cf. Shaw 1999: 598, n. 105. Although I could not supply myself with 
the translation of Mystagogia Shaw had at his disposal, I believe the renditions above, apart from being selective, do not perfectly reflect the Greek text, where Maximus says precisely the following (bold phrases are made intentionally to correspond to

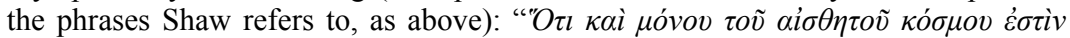

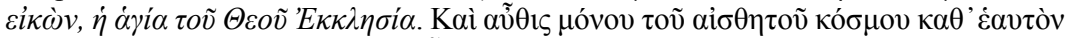

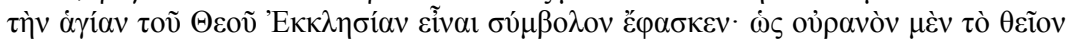

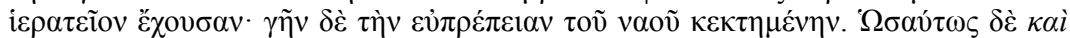

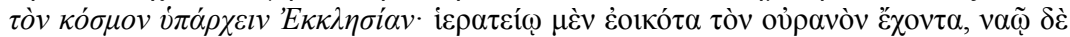

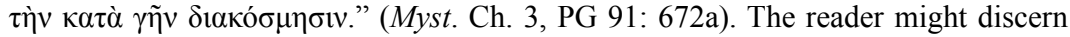
certain concealments that allow Shaw to conclude, by means of a selective reading of this Maximian passage that "the world as church or temple is perfectly consistent with the principles of Iamblichean theurgy, so long as our church is not the only church." I fully align myself with Shaw, however, in his objection about the church; I agree with him, since for both Dionysius and Maximus, the church is definitely not the one he rightly feels allergic about.

114 The epistemic implications of this identification are enormous, but this would need a separate study.

115 For instance, Shaw's introductory wonder, in Shaw 1999, is "why are Christian theologians reluctant to admit that Dionysius was a theurgist." By "theurgist" Shaw refers to the Iamblichean definition of a theurgist as a man who performs theurgic rituals.

116 Iamblichus, De Myst. V.18-19, 225.1-4; Clarke et al. 2003: 256-259.

117 Dodds 1963: 283. On the origins and the meaning of the term " $\mu \alpha \gamma \varepsilon i ́ \alpha$," see Bull 2018: 398-404. Bull builds on the definition of "religion" as "an institution consisting of culturally patterned interaction with culturally postulated superhuman beings," by Melford Spiro, and provides the following definition of "magic": "then magic should be considered a subgroup of religion, since it consists of a specific form of interaction with the culturally postulated beings. If religion is 'institution', then magic is specific rituals performed within or - perhaps more commonly - on the fringes of said institution." I do not mean to say that Iamblichus considers theurgy as magic. He is quite

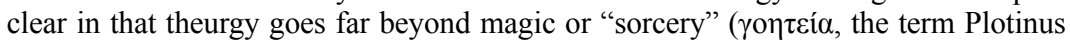
uses in his Enneads), the latter relying on sympathies within the material world; for him, theurgy requires the involvement of the divine will of gods. I simply mean that, from a Christian point of view, Iamblichean theurgy is about magic so long as it does not acknowledge a single divine activity of one God; a singular activity that is, the more, not dependent on an evocation of a manifold of deities. For the relationship between theurgy, magic and religious practices in Late Antiquity, see Addey 2014: 32-38.

118 Stock 2013: 14.

119 Unlike the Timaeus, and the entire Neoplatonic tradition, Dionysius has a creator god who brings the universe into being theurgically, without the aid of subordinate gods, cf. Lossky 1983: 124-125.

120 See nn. 20 and 121.

121 I fully agree with István Perczel who argues that in "Dionysius' Christian Platonist system (...) the creating activity is not distributed among different divine entities or hypostases like in Proclus, but is attributed to the highest and universal cause of all things. Proclus' Demiurge is a subordinate deity occupying a rather modest rank in

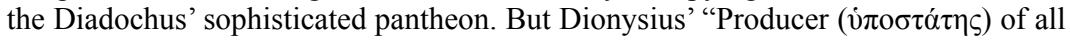
things" is the supreme Godhead (. . .)." Cf. Perczel 2000: 494.

122 I think here Burns is absolutely right. Cf. Burns 2004: 127.

123 I very much agree with Shaw's criticism of the "institutional church," cf. Shaw 1999: 599. 


\section{Panagiotis G. Pavlos}

\section{Bibliography}

\section{Primary sources}

\section{a. Editions}

Clarke, Emma C., John M. Dillon and Jackson P. Hershbell (eds. and trans.) (2003). Iamblichus, De Mysteriis. Atlanta, GA: Society of Biblical Literature.

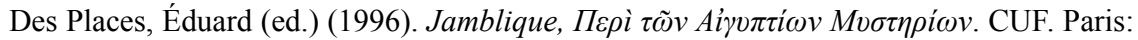
Les Belles Lettres.

Dillon, John M. (ed.) (1973). Iamblichi Chalcidensis In Platonis dialogos commentariorum fragmenta. Leiden: Brill.

Heil, Günter and Adolf M. Ritter (eds.) (1991). Corpus Dionysiacum II. Pseudo-Dionysius Areopagita, De Coelesti hierarchia, De ecclesiastica hierarchia, De mystica theologia, Epistulae. Berlin/Boston: De Gruyter.

Henry, Paul and Hans-Rudolf Schwyzer (eds.) (1964-1982). Plotini Opera. Scriptorum Classicorum Bobliotheca Oxoniensis. 3 Vols. Oxford: Clarendon Press.

Hicks, Robert Drew (ed. and trans.) (1972). Diogenes Laertius, Lives of Eminent Philosophers. Books 1-5. LCL. Vol 184. Cambridge, MA: Harvard University Press.

Migne, Jacques-Paul (ed.) (1857). Dionysius Areopagita. PG. Vols. 3-4. Paris: Imprimerie Catholique.

Nasta, Michai (ed.) (1993). Thesaurus Pseudo-Dionysii Areopagitae. Corpus Christianorum Thesaurus Patrum Graecorum. Turnhout: Brepols.

Suchla, Beate Regina (ed.) (1990). Corpus Dionysiacum I. Pseudo-Dionysius Areopagita, De Divinis Nominibus. PTS. Vol. 33. Berlin/New York: De Gruyter.

\section{b. Translations}

Emilsson, Eyjólfur Kjalar and Steven Keith Strange (eds. and trans.) (2015). Plotinus, Ennead VI.4 and VI.5: On the Presence of Being, One and the Same, Everywhere as a Whole. Las Vegas/Zurich/Athens: Parmenides Publishing.

Parker, John (trans.) (1897). Dionysius the Areopagite, Works. Oxford: James Parker and Co.

\section{Scholarly literature}

Addey, Crystal (2014). Divination and Theurgy in Neoplatonism: Oracles of the Gods. London/New York: Routledge.

Armstrong, Arthur Hilary (1973). "Man in the Cosmos: A Study of Some Differences between Pagan Neoplatonism and Christianity." In Romanitas et Christianitas, ed. Willem den Boer, Pieter G. Van der Nat, Christiaan Marie Jan Sicking, and Jacobus C.M. Van Winden, 5-14. London: North Holland.

Bull, Christian H. (2018). The Tradition of Hermes Trismegistus: The Egyptian Priestly Figure as a Teacher of Hellenized Wisdom. Religions in the Graeco-Roman World. Vol. 186. Leiden/Boston: Brill.

Burns, Dylan (2004). "Proclus and the Theurgic Liturgy of Pseudo-Dionysius." Dionysius 22: 111-132.

Chlup, Radek (2012). Proclus: An Introduction. Cambridge: Cambridge University Press. 
Coughlin, Rebecca (2006). "Theurgy, Prayer, Participation, and Divinization in Dionysius the Areopagite." Dionysius 24: 149-174.

Damian, Theodor (2011). "The Doctrine of Creation in Pseudo-Dionysius Areopagite's Theology." Annals of the Academy of Romanian Scientists: Series on Philosophy, Psychology, Theology and Journalism 3.1-2: 89-112.

Dillon, John M. (2014). “Dionysius the Areopagite.” In Interpreting Proclus: From Antiquity to the Renaissance, ed. Stephen Gersh, 111-124. Cambridge: Cambridge University Press.

Dodds, Eric R. (1963). The Greeks and the Irrational. Berkeley: University of California Press.

Emilsson, Eyjólfur Kjalar (1999). "Remarks on the Relation between the One and the Intellect in Plotinus." In Traditions of Platonism: Essays in Honour of John Dillon, ed. John J. Cleary, 271-290. Aldershot: Ashgate.

Finamore, John (2014). "Iamblichus on Soul." In The Routledge Handbook of Neoplatonism, ed. Pauliina Remes and Svetla Slaveva-Griffin, 280-292. London/New York: Routledge.

Florovsky, Georges (1987). The Byzantine Ascetic and Spiritual Fathers. Vol. 10 in The Collected Works of Georges Florovsky, ed. Richard S. Haugh. Vaduz: Büchervertriebsanstalt.

Golitzin, Alexander (1999). “'A Contemplative and a Liturgist': Father Georges Florovsky on the Corpus Dionysiacum.” St Vladimir's Theological Quarterly 43: 131-161.

- (2013). Mystagogy: A Monastic Reading of Dionysius Areopagita. 1st edition 1994. Cistercian Studies Series 250. Collegeville: Cistercian Publication.

Gontikakis, Vasileios (1984). Hymn of Entry, Liturgy and Life in the Orthodox Church. New York: St. Vladimir's Seminary Press.

Grillmeier, Alois and Theresia Hainthaler (eds.) (2013). Christ in Christian Tradition. Vol. 2, Part 3. Oxford: Oxford University Press.

Ivanovic, Filip (2017). "Union with and Likeness to God: Deification According to Dionysius the Areopagite." In Visions of God and Ideas on Deification in Patristic Thought, ed. Mark Edwards and Elena Ene D. Vasilescu, 118-157. London/New York: Routledge.

(2019). Desiring the Beautiful: The Erotic-Aesthetic Dimension of Deification in Dionysius the Areopagite and Maximus the Confessor. Washington, DC: The Catholic University of America Press.

Lossky, Vladimir (1983). The Vision of God. Crestwood, NY: St. Vladimir's Seminary Press.

Louth, Andrew (1986). "Pagan Theurgy and Christian Sacramentalism in Denys the Areopagite." The Journal of Theological Studies, New Series 37.2: 432-438.

(1989). Denys the Areopagite. London/New York: Continuum.

Mazur, Zeke (2004). "Unio Magica: Part II: Plotinus, Theurgy and the Question of Ritual." Dionysius 22: 29-55.

Nasta, Michai (ed.) (1993). Thesaurus Pseudo-Dionysii Areopagitae. Corpus Christianorum Thesaurus Patrum Graecorum. Turnhout: Brepols.

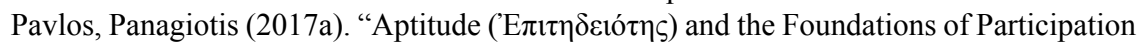
in the Philosophy of Dionysius the Areopagite." Studia Patristica 96: 377-396.

- (2017b). "Christian Insights into Plotinus' Metaphysics and His Concept of Apti-

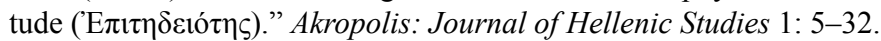

Perczel, István (2000). "Pseudo-Dionysius and the Platonic Theology: A Preliminary Study." In Proclus et la Théologie Platonicienne. Actes du Colloque International de Louvain (13-16 Mai 1998). En l'honneur de H.-D. Saffrey et L.G. Westerink, 
ed. Alain-Philippe Segonds and Carlos Steel with the Help of Concetta Luna and A. F. Mettraux, 425-443. Leuven/Paris: Leuven University Press/Les Belles Lettres.

Rist, John M. (2010). Plotinus: The Road to Reality. 1st edition 1967. Cambridge: Cambridge University Press.

Rorem, Paul (1984). Biblical and Liturgical Symbols within the Pseudo-Dionysian Synthesis. Studies and Texts 71. Toronto: Pontifical Institute of Medieval Studies.

Russell, Norman (2006). The Doctrine of Deification in the Greek Patristic Tradition. Oxford: Oxford University Press.

Saffrey, Henri-Dominique (1966). "Un lieu objectif entre le Pseudo-Denys et Proclus." In SP IX, Texte und Untersuchungen zur Geschichte der Altchristlichen Literatur, Bd. 92-94, ed. Frank Leslie Cross. Berlin: Akademie-Vorlag.

(1982). "New Objective Links between the Pseudo-Dionysius and Proclus." In Neoplatonism and Christian Thought, ed. Dominic O'Meara, 64-74. Albany: State University of New York Press.

Sambursky, Samuel (1962). The Physical World of Late Antiquity. London: Routledge/ Kegan Paul.

Schroeder, Frederic M. (2014). "From Alexander of Aphrodisias to Plotinus." In The Routledge Handbook of Neoplatonism, ed. Pauliina Remes and Svetla Slaveva-Griffin, 293309. London/New York: Routledge.

Shaw, Gregory (1995). Theurgy and the Soul: The Neoplatonism of Iamblichus. University Park, PA: The Pennsylvania State University Press.

_ (1999). "Neoplatonic Theurgy and Dionysius the Areopagite." Journal of Early Christian Studies 7.4: 537-599.

Sorabji, Richard (ed.) (1990). Aristotle Transformed: The Ancient Commentators and Their Influence. London: Duckworth.

Stock, Wiebke-Marie (2013). "Theurgy and Aesthetics in Dionysios the Areopagite." In Aesthetics and Theurgy in Byzantium, ed. Sergei Mariev and Wiebke-Marie Stock, 13-30. Berlin/New York: De Gruyter.

Struck, Peter (2001). "Pagan and Christian Theurgies." The Ancient World: Mystery Religions and Philosophy of Late Antiquity 32.1: 25-38.

Tollefsen, Torstein Theodor (2008). The Christocentric Cosmology of St Maximus the Confessor. Oxford: Oxford University Press.

Van den Berg, Robbert Maarten (2014). "The Gift of Hermes: The Neoplatonists on Language and Philosophy." In The Routledge Handbook of Neoplatonism, ed. Pauliina Remes and Svetla Slaveva-Griffin, 251-265. London/New York: Routledge.

Vanneste, Jean S.I. (1959). Le Mystère de Dieu. Essai sur la structure rationelle de la doctrine mystique du Pseudo-Denys l'Aréopagite. Brussels: Desclée de Brouwer.

Wear, Sarah Klitenic and John M. Dillon (2007). Dionysius the Areopagite and the Neoplatonist Tradition: Despoiling the Hellenes. Aldershot: Ashgate. 
understood in the arrogant terms of one thing's exceeding another in power, ${ }^{97}$ but rather in the humble terms of the image of Christ, who descends in order to initiate us in the mysteries of Divine Love.

The application of "hierarchy" not only to the human and heavenly spheres, but also to Divinity, suggests that there is one overall chain of hierarchies which at its top has the Archpriest ${ }^{98}$ Christ, followed by various "classes." 99 This is why the names of each sphere can be extended to the others, too. Both hierarch and Christ are called "angel," 100 while the angels are compared to hierarchs. ${ }^{101}$ Thus, in Dionysius we have a stricter and looser use of "hierarch," referring on the one hand to the human official and on the other to any entity that carries out the functional role described above: a communication of knowledge that can be carried out by a higher "messenger," which is of course the original meaning of "angel," 102 or even by Christ.

This brings us to the function of Dionysius' own Hierarchies, and his hierarchical role as their author. Dionysius is a presbyter, i.e. a priest, whose own hierarch is Hierotheus, even if he is also ultimately (and supposedly) a student of Paul. ${ }^{103}$ Hence, Dionysius' task is the illumination of the initiated, and especially of his readers. ${ }^{104}$ Historically the priests would assist hierarchs in the performance of rituals and in teaching. This is not to say that Dionysius' books are themselves rituals or mysteries, but the Ecclesiastical Hierarchy is largely about the sacraments, and helps us to understand the sacred meaning of the mysteries. Meanwhile the Celestial Hierarchy informs us about the symbolisms of the angels in Scripture and in paintings. Both books teach about the structure of the hierarchies, in an attempt to

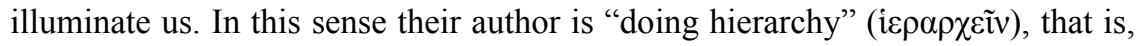
trying to spark within us the light that will inflame our desire for God. ${ }^{105}$

\section{Conclusion}

If all this is right, then our modern sense of hierarchy has lost much of the original meaning invested in the term by Dionysius. For him, relating "hierarchically" is not merely or mostly to outrank someone, but to invite someone to move up to God. Just consider how Franz Kafka (1883-1924) suggests in works like The Trial that due to its innumerable layers, hierarchy distances us from any supreme authority that could guarantee justice. Dionysian hierarchy is the reverse: a result of Christ's loving providence, and a dynamic process for closing the gap between us and Him, as far as possible.

\section{Notes}

* I am grateful to Peter Adamson for his detailed philosophical and editorial comments, and to Panagiotis G. Pavlos for his penetrating remarks. This article was written within the DFG-Project: "Natur in politischen Ordnungsentwürfen: AntikeMittelalter-Frühe Neuzeit" (LMU, Munich).

1 See for instance O'Meara 1975.

2 Cf. Stiglmayr 1898: 181.

3 Cf. Wear and Dillon 2007: 7, 11, 56, n. 27. 
4 Cf. Rorem's n. 11 in Luibheid and Rorem 1987: 197-198. The persona of the unknown author, Saint Dionysius the Areopagite, was a convert of Saint Paul after his famous sermon in Athens; cf. Acts 17:34.

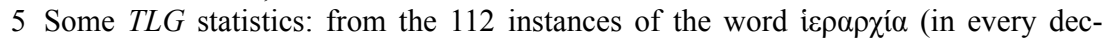
lination and number) in the $C D$, only one is to be found in the $D N$. All the other

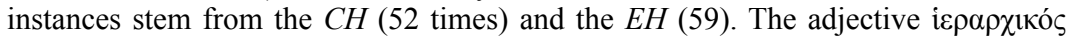
(in every form) has a total of 83 instances: $C H 11 ; E H 67 ; D N 3 ; E p .82$ times. The adverb i $\varepsilon \rho \alpha \rho \chi 1 \kappa \tilde{\omega} \varsigma$ appears thrice in the $C H$ and 16 times in the $E H$. The designation

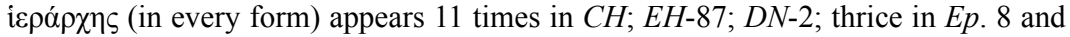
also in the titles of the Ep. 7 and 9, although the titles are generally disputed as later

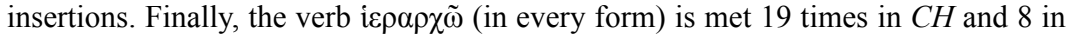
$E H$. Note the absence of these terms from the $M T$.

6 These two books form a unity. The right order is to start reading the $\mathrm{CH}$ and conclude with the $\mathrm{EH}$, since in the $\mathrm{CH}$ one finds an introduction to the notion of hierarchy per se. The contents of the books are mutually complementary. As to how they might contribute to Dionysius' overall project see different proposals by Luibheid and Rorem 1987: 140, n. 17, Golitzin 2013: xxxiv; Andreopoulos forthcoming (I thank the author for having sent me a draft). The Dionysian texts used are Suchla 1990 (for $D N$ ) and Heil and Ritter 2012 (for the Corpus' rest treatises). In my references I give the number of the chapter/section, the pagination/lineation (separated by a full-stop) of the standard critical edition, as well as the pagination from Migne's PG (along with the number of the volume, because they are used in English translations).

7 We should not overlook, however, the precedents in Christian (especially ascetic) literature; see Golitzin 2013: 50-56, 305-364, xxxiv - xxxv, n. 43, and Golitzin 1994: 233ff., especially 319-392.

8 See Dodds 1963, propositions 25-39.

9 See Vasilakis 2014: (chapters 2-3).

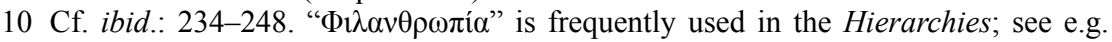
Dionysius, EH III.8, Heil and Ritter 2012: 88.10; PG 3: 437a.

11 Cf. Plato, Theaet. 173a4-8.

12 Cf. idem, Rep. VII, 514a1-518b5.

13 Translations of Dionysius are my own. I have been assisted by the Modern-Greek translation of Dionysius by Sakalis 1985. Regarding the widely available English translation by Luibheid and Rorem 1987, Arthur 2008: xi notes that the "sheer readability and capacity for conveying the personality and emotions behind the words have made Dionysius much more accessible than he would have been otherwise." However, Perl is right in criticising Luibheid and Rorem 1987 as being more a paraphrase than a translation of Dionysius' complex Greek; see Perl 2007: ix. Cf. also Knepper 2014: xi.

14 Dionysius, $C H$ IX.3, Heil and Ritter 2012: 38.16-20; PG 3: 261a. (My additions in square brackets.) About the Old Testament figure of Melchisedek see Gen 14:18-20; Hebr 7:1-28, passim.

15 About the Dionysian Hierarch see: EH I.3, Heil and Ritter 2012: 66.1-6; PG 3: 373c, $E H$ II.3, Heil and Ritter 2012: 75.3-9; PG 3: 400b, and EH III.3, Heil and Ritter 2012: 83.3-10; PG 3: 429a-b.

16 I promise to do part of this in future papers. For Dionysius' relation to pagan Neoplatonism see also Pavlos' chapter in this volume on the notion of theurgy in the Areopagite, esp. its first part ("Methodological Concerns"), as well as the general methodological framework set out in the Introduction to this volume.

17 As a preliminary to pagan Neoplatonic, and especially Proclus' views on hierarchy I recommend Terezis 2002.

18 See also infra, n. 22.

19 Short paraphrase of the beginning of Plato, Tim. 17a1-2. 
20 The reader will find in Dionysius' Hierarchies other definitions, which do not contradict each other, although sometimes have different formulations. See e.g. EH I.3, Heil and Ritter 2012: 65.22-24; PG 3: 373c and CH III.2, Heil and Ritter 2012: 18.10-13; PG 3: 165 b.

21 Such a gesture, underlining the author's personal contribution to the tradition handed to him, is met also in Proclus; cf. e.g. Proclus, In Alc. 125.2 (Westerink).

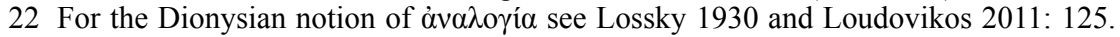
It forms one of the bridges from Dionysius to Maximus the Confessor; contrast the approach in Gavin 2008 and Stang 2012: 114. For the absence of the term "hierarchy" and its cognates in Maximus (save for two unimportant occurrences) see Constas 2017: 8, n. 34.

23 Dionysius, CH III.1, Heil and Ritter 2012; 17.3-9; PG 3: 164d.

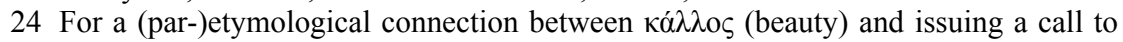

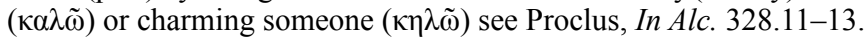

25 Cf. also Perczel 2015: 215.

26 Dionysius, $C H$ IX.2, Heil and Ritter 2012: 37.10-13; PG 3: 260b. See also de Andia 1996 and Ivanovic 2017.

27 See the thorough analysis by Golitzin 2013: 161-191, in addition. One could draw an analogy with the Dionysian, as well as Neoplatonic, triadic division of divine intellects into being (corresponding to order), power (or capacity, corresponding to understanding) and activity; cf. CH XI.2, Heil and Ritter 2012: 42.1-2; PG 3: 284d.

28 Here, as in general, Dionysius' language is ambivalent between initiation $(\tau \varepsilon \lambda \varepsilon \dot{\varepsilon} \omega-\tilde{\omega} /$

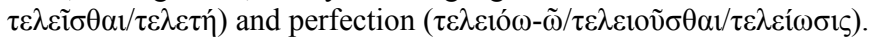

29 Dionysius, $C H$ III.2, Heil and Ritter 2012: 18.17-19.2; PG 3: 165b-c.

30 In Greek these "classes" can be again termed as " $\tau \alpha \dot{\xi} \xi \varepsilon 1 \varsigma$." In fact, in $C D$ " $\tau \alpha \dot{\xi} \xi 1 \zeta$ " is interchangeable with " $\delta 1 \alpha \kappa o ́ \sigma \mu \eta \sigma ı \varsigma "$ (arrangement). From the manifold cases, see: CH III.2, Heil and Ritter 2012: 18.11; PG 3: 165b; CH III.3, Heil and Ritter 2012: 19.21; PG 3: 168a; CH IX.2, passim., e.g. Heil and Ritter 2012: 36.12-14 and 24; PG 3: 257c and 260a; $C H$ X.2, Heil and Ritter 2012: 40.16 and 18; PG 3: $273 \mathrm{~b}$.

31 Cf. also Louth 1989: 65, 66.

32 See also $C H$ VII.2, Heil and Ritter 2012: 28.20-23; PG 3 208a-b.

33 "System" for $\pi \rho \alpha \gamma \mu \alpha \tau \varepsilon i ́ \alpha$. Cf. $L S J$ ad lem. III. (1.b).

34 Dionysius, $E H$ V.1, Heil and Ritter 2012: 104.11-15; PG 3: 501a.

35 The existence of the following genitives leads us to take $\mu \varepsilon \tau о \chi \eta$ as "participation",

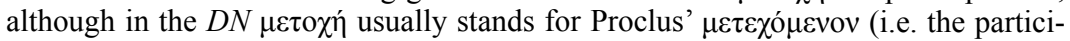
pated entity). Cf. Vasilakis 2014: 223, n. 63.

36 Dionysius, $C H$ VII.2, Heil and Ritter 2012: 28.15-17; PG 3: 208 a.

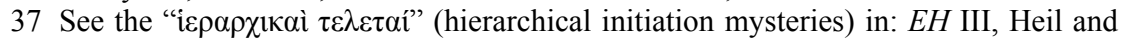
Ritter 2012: 79.8; PG 3: 424c; cf. ibid.: 79.15; PG 3: 424d, and ibid.: 19; PG 3: 425a.

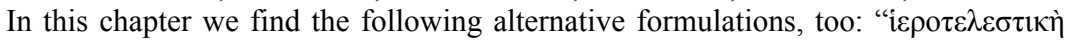
$\pi \rho \alpha \gamma \mu \alpha \tau \varepsilon i$ ' " (sacredly initiating operation, with Luibheid and Rorem $1987 \mathrm{ad}$ loc.) in

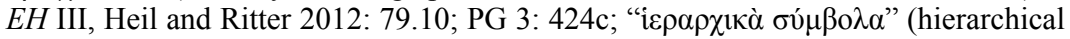

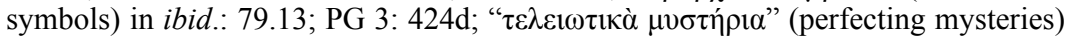
in ibid.: 79.17; PG 3: 425a, and EH III.4, Heil and Ritter 2012: 83.12; PG 3: 429c; " $\tau \grave{\alpha}$

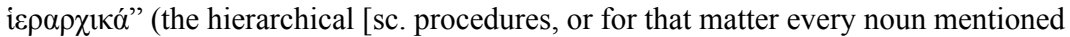
previously]) in EH III, Heil and Ritter 2012: 80.1; PG 3: 425a. Another alternative, the

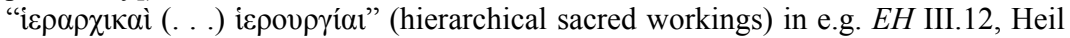

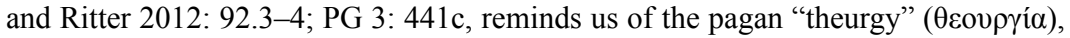
suffused with Neoplatonic philosophy first by Iamblichus, for which see infra, n. 62 .

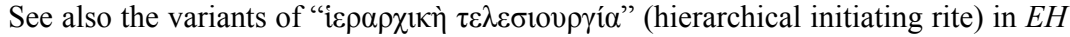

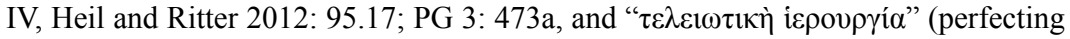
sacred working) in ibid.: 95.19; PG 3: 473b.

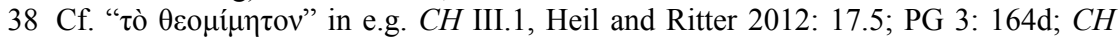
III.2, Heil and Ritter 2012: 18.15; PG 3: 165b, and CH XIII.3, Heil and Ritter 2012: 45.20; PG 3: 301c. 
39 In my terminology I consciously avoid entering into the debate of Neoplatonic emanation versus Christian creation. The main reason is that, although I have not found any evidence in support of emanationism in Dionysius, the author seems to consciously avoid entering into the aforementioned debate either. Instead he uses terminology such as "production" ( $\pi \alpha \rho \alpha \gamma \omega \gamma \eta$ ); cf. e.g. DN II.11, Suchla 1990: 136.3; PG 3: 649b and DN I.5, Suchla 1990: 117.15; PG 3: 593d (adding here the noun "نं $\delta$ ó $\alpha \sigma ı \varsigma$ "/subsistence), as well as nn. 20 and 121 from Pavlos' chapter in

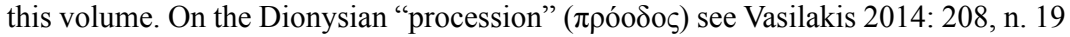
and $219-220$, nn. $50-52$.

40 I am borrowing the expression "ó $\pi \alpha \tau \rho ı c_{\varsigma} \varsigma$ o $\rho \mu о \varsigma$ " from Proclus; cf. his Theologia Platonica, vol. 1: 302.23-24, and vol. 4: 43.19; 64.24; 77.20 (Saffrey-Westerink), as well as Van den Berg 2000.

41 Dionysius uses erotic terminology in his Hierarchies, too. See the following examples

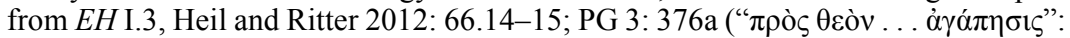

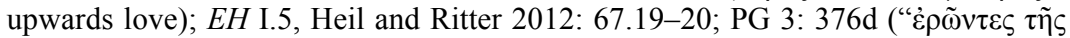

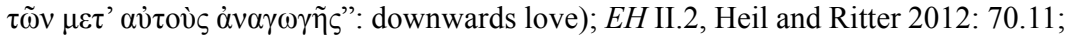

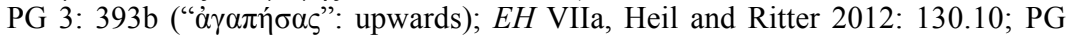

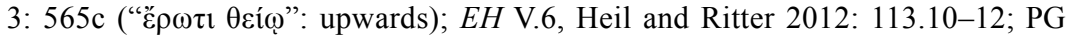

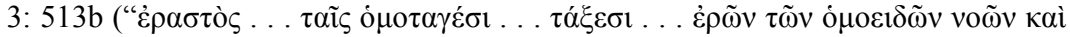

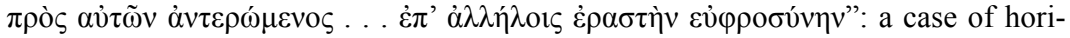
zontal eros, between beings of the same stratum, although the structure of a single stratum is another story; " $\alpha \dot{v} \tau \varepsilon \dot{\varepsilon} \rho \omega \varsigma$," as loving response, is used by Plato in his erotic dialogue, Phaedrus 222e1. Cf. Vasilakis 2014: 115, n. 74). Regarding the connection between hierarchy and love (in both directions) see also Riggs 2009, Terezis and Panagopoulos 2009, as well as Perl 2013. I agree with almost every point of Perl's, except for his view (ibid.: 24) that the metaphysics of hierarchy is more fully presented in the $D N$ than in $C H / E H$. $D N$ forms the starting, as well as focal, point of Menelaou 2017, too.

42 Cf. Vasilakis 2014: 234-248. That Socrates in only a "medium" entity, whereas Christ is perfect God (and man) is the basic difference between the Dionysian hierarchy and the Socratic providential/educational love with which Proclus deals in the Alcibiades ' Commentary. Cf. also Vasilakis 2017: 409-410, n. 13, while for the connection between Proclus and Dionysius in this respect see Pallis 2017: 288.

43 Cf. Drăgulin 1979. Since I do not read Romanian, what I know about this book I owe to Meyendorff 1980. It is to his credit that despite disliking Dionysius he wrote this sober review, and to the credit of Rorem that, although in Luibheid and Rorem 1987 there is almost no reference to any Orthodox scholar (or Byzantine Father), he included this valuable reference (ibid.: 198, n. 11; the reference in ibid.: 155, n. 47 to Louth 1981 must be from the time the latter was an Anglican priest).

44 Cf. DN III.2, Suchla 1990: 140.3-4; PG 3: 681a. Historical fiction is different to spiritual indebtedness.

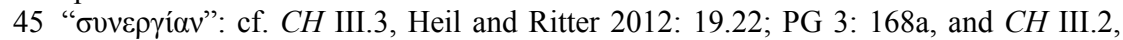

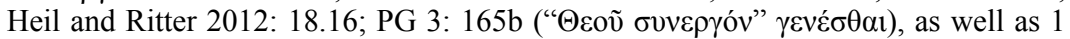
Cor 3:9. Cooperating with God means being in harmony with God's creation, hence in $\mathrm{CH}$ I.3, Heil and Ritter 2012: 9.9; PG 3: 124a, Dionysius calls the human hierar-

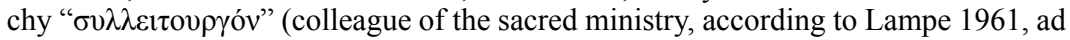
lem.) of the celestial one.

46 " $\theta$ เ $\sigma \tilde{\omega} \tau \alpha$ ”": cf. $C H$ II.1, Heil and Ritter 2012: 9.16; PG 3: 136d; $C H$ III.2, Heil and

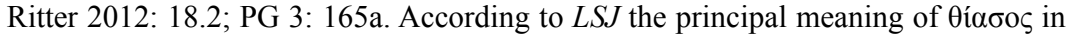
Classical Greek is that of a "Bacchic revel."

47 Dionysius, $C H$ III.2, Heil and Ritter 2012: 18.3-6; PG 3: 165a.

48 Although Dionysius' Greek has " $\theta \varepsilon \sigma \mu o u ́ \varsigma$ " here, the cognate " $\theta \varepsilon \dot{\varepsilon} \mu \varsigma$ " of Plato, Tim. 30a6-7 seems relevant, especially in light of what comes in my text. Cf. also Dionysius' use of the cognate " $\theta \varepsilon \mu 1 \tau$ óv" in $C H$ III.2, Heil and Ritter 2012: 18.5-7; PG 3: $165 \mathrm{a}$. 
49 Alternative translation, which does not betray the etymology, though: "superabundantly."

50 Cf. Tim. 29e1-3.

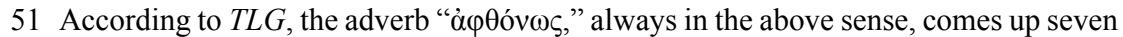
times in Proclus' works; see for instance, El. theol., prop. 122, 1.11 (Dodds 1963); Theol. Plat. 6: 23.2; In Alc. 90.23.

52 See another instance in Dionysius: EH II.3, Heil and Ritter 2012: 75.4-7; PG 3: 400b.

53 See $C H$ XIII.3, Heil and Ritter 2012: 46.1-5; PG 3: 301d, with the third definition of hierarchy in $C H$ III.3, Heil and Ritter 2012: 19.21-20.2; PG 3: 168a-b.

54 Another cognate of the previous passage's " $\theta \varepsilon \sigma \mu$ oi"; for the latter see also $E H$ V.4, Heil and Ritter 2012: 106.24-25; PG 3: 504c and the relevant entry in the short Dionysian lexicon included in Terezis and Petridou 2017: 110.

55 Or supernatural, as Dionysius adds in CH III.3, Heil and Ritter 2012: 19.23-20.1; PG 3: 168a; cf. an analogous move in Proclus, El. theol., prop. 122, 9.

56 Cf. $C H$ III.2, Heil and Ritter 2012: 18.11; PG 3: 165b, as well as Louth 1989: 67 and Ivanovic 2011: 40.

57 Its translation as "understanding" in order to denote a knowledge that is firmly grounded is justified by the fruitful scholarly debate about the use of the term in Plato and Aristotle. Cf. Burnyeat 2012.

58 See $C H$ III.3, Heil and Ritter 2012: 19.9-14; PG 3: 165d.

59 Dionysius, $C H$ III.3, Heil and Ritter 2012: 19.12-14; PG 3: 165d.

60 Dionysius, $\mathrm{CH}$ III.3, Heil and Ritter 2012: 19.19; PG 3: 168a; cf. also the con-

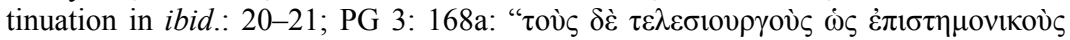

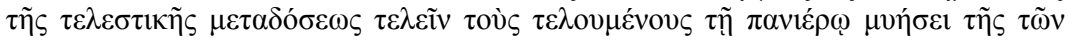

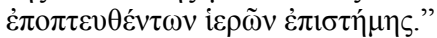

61 Here we can draw a parallel to the Cappadocian idea that theoretical knowledge of God (which should be acquired by the recipient in the hierarchical case) corresponds to virtuous practical action (in the mediator). Cf. Kobusch 2017: 164.

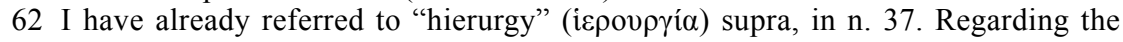
Dionysian notion of theurgy see e.g. EH III.5, Heil and Ritter 2012: 84.18 and 21; PG 3: 432b and EH IV.12, Heil and Ritter 2012: 103.2-4, 16-18 and 21-22; PG 3: 484d-485b with Stock 2008: 152-170; concerning its differences from pagan Neoplatonic theurgy see Louth 1986: 432-435. See also Burns 2004 with further bibliography, as well as a fine insistence on the person and activity of Christ as a central difference between Proclus and Dionysius (ibid.: 127-128, 132), which is of course a central aspect of Pavlos' contribution on Dionysian theurgy to this volume.

63 Cf. EH V.3, Heil and Ritter 2012: 106.17-22; PG 3: 504b-c.

64 For proponents see e.g. Vanneste 1959 from Roman Catholic side and archimandrite Sophrony 2016: passim. from the Orthodox one. (I thank Dimitrios Pallis for discussing with me this point and suggesting bibliography here and elsewhere.) Proponents of the experiential side of the Areopagite are for instance Lossky 1968 and Yannaras 2005, who gives a Palamite interpretation of the Areopagite (i.e. befitting saint Gregory Palamas' theology, 1296-1359), and attributes the intellectualist reading to Western/scholastic figures, such as Thomas Aquinas (1225-1274).

65 See for instance Revelation 4:4 and 8; 5:6; Golitzin 2013: 16-17; (Metropolitan Kallistos) Ware 2011: 233, speaking "of the Divine Liturgy as 'heaven in earth"”; Bradshaw 2015: especially n. 28 with further bibliography.

66 See e.g. $C H$ VII.1, Heil and Ritter 2012: 27.8-9; PG 3: 205b: "[T]he first of the heavenly hierarchies is sacredly performed by the most exalted substances" ( $\dot{\eta} \pi \rho \omega ́ \tau \eta \tau \tilde{\omega} v$

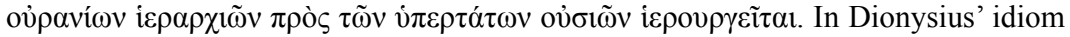
the agent is usually denoted by the $\pi \rho$ ó $\varsigma$ gen. construction, instead of the more common vं ó + gen.). If something is sacredly performed, then this would be a mystery of the Church, a sacred activity and rite; compare the formulations in $E H$ III, Heil and 
Ritter 2012: 80.5-6; PG 3: 425b; CH VI.1, Heil and Ritter 2012: 26.1-2 and 5-6; PG 3: 200c. See also supra, nn. 37, 62, 63.

67 Cf. Luibheid and Rorem 1987: 165, n.79 and the longer n.75, ibid.: 163.

68 Dionysius, $C H$ VII.3, Heil and Ritter 2012: 30.22-31.5; PG 3: 209c-d. The context relates to the first/highest celestial order.

69 See Andreopoulos forthcoming, which is on a par with the monastic reading of hieromonk (and now Archbishop Alexander) Golitzin 1994, one of Areopagite's most profound interpreters. See Newheiser 2010 for some critique, as well as the more recent contribution of Golitzin 2013: passim, e.g. 16, 17, 25, 28, 40, 44, 50.

70 Cf. Andreopoulos forthcoming: (4, 6); cf. also Pallis 2017: 297.

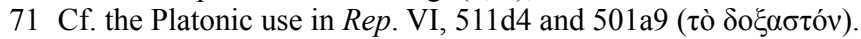

72 Cf. Andreopoulos forthcoming: (5).

73 Cf. Louth 1986: 438, speaking though only in the context of $E H$, and Ivanovic 2011: 42. Within this line of interpretation it has also been proposed that "Sacramental Theology" would be a better translation for the title of the work. Cf. Andreopoulos forthcoming: (3). Rorem 2015 has a totally different reading. For criticism of the latter see Golitzin 2013: xxxii, xxxvi, 34-36. For a history of the development of Christian Orthodox worship, mainly liturgical, see Rentel 2006.

74 In this way an understanding of intellectualist brand is subsumed in the ritual, i.e. liturgical, component mentioned above. For such a rich understanding of "understanding", see also infra, n. 77. Let us not forget that Christ is not only the Truth (" $\alpha \lambda \hat{\eta} \theta \varepsilon 1 \alpha "$ according to John 14:6), but also Love made flesh (cf. 1 John 4:8-9; cf. also in the list of $D N$ I.6, Suchla 1990: 118.11-119.1; PG 3: 596a-b). He is not a mere intellectual object of knowledge, but a Lover, who issues an erotic call to His beloved cosmos, becoming himself the Beloved (cf. 1 John 4:19). In this sense, one gets to know another person deeply, only when he/she genuinely loves her/him. It is in this much richer erotic framework that John speaks of knowledge, and I suggest that the same we should do for Dionysius, too (whether the noun in question is " $\gamma v \tilde{\omega} \sigma 1 \varsigma$ " or

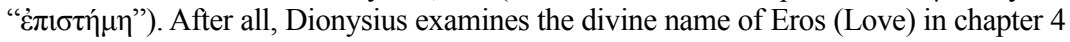
of $D N$, while he gets to "intellectual" names later, in chapter 7 .

75 Cf. DN III.2, Suchla 1990: 139.17-18 and 140.3-4; PG 3: 681a.

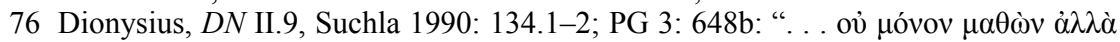

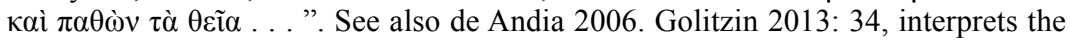
formula as " "suffering' the mystery of the Incarnation"; cf. also ibid.: 40 (on Moses). In any case, I take this formula as an apt manifestation of Dionysian "understanding."

77 There could be three more candidates here, but I will not discuss them: the "Legal" hierarchy, i.e. the hierarchy we find in the Old Testament which in linear (non-vertical) terms of time antedates the ecclesial hierarchy that was inaugurated with Christ's incarnation. See e.g. $E H$ V.1, Heil and Ritter 2012: 105.3-106.3; PG 3: 501b-504a; the internal hierarchy of soul from Ep. 8, 3-4, Heil and Ritter 2012: 182.3-184.2 (cf. CH X.3, Heil and Ritter 2012: 40.23-41.4; PG 3: 273c), reminiscent of the Platonic Republic's analogy between city and soul (compare however Golitzin 2013: 17-18, 21-24); finally, the ontological chain from soulless beings up to humans and angels, which we could call "cosmic hierarchy," though Dionysius himself does not apply the word in this way. See CH IV.1, Heil and Ritter 2012: 20.11-19; PG 3: 177c-d, and cf. for confirmation Biriukov 2015: 83-84.

78 Cf. Ivanovic 2011: 29, and Luibheid and Rorem 1987: 195, n. 2.

79 Dionysius, EH VI.5, Heil and Ritter 2012: 119.8-15; PG 3: 536d-537a.

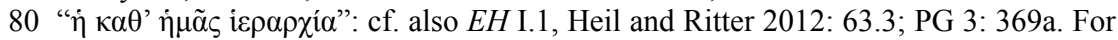
Golitzin 2013: 25 this is the "church at worship," i.e. liturgy; cf. also Golitzin 2003: 186.

81 Cf. e.g. $C H$ VIII.2, Heil and Ritter 2012: 35.21-25; PG 3: 241c.

82 An exceptional case where a plural is used for the human hierarchy, too. Cf. also Luibheid and Rorem 1987: 171, n. 100. 
83 Dionysius, $C H$ IX.2, Heil and Ritter 2012: 37.3-11; PG 3: 260a-b.

84 Dionysius was so fond of inventing names, starting with his own, that he did not take rest by interpreting biblical names of God in the $D N$, but went on to this project in his Hierarchies.

85 This ascription, which is Dionysius' coinage, too (cf. Louth 1986: 437), is frequently used in $C D$; see e.g. $E H$ I.5, Heil and Ritter 2012: 67.17; PG 3: 376d.

86 See a word-play in $C H$ VII.2, Heil and Ritter 2012: 29.19; PG 3: 208d. Dionysius liked linguistic jokes, too; in $C H$ II.2, Heil and Ritter 2012: 11.4; PG 3: 137d, the mention of the noun in the formula "o $\rho v \imath \theta \varepsilon i \alpha$ a $\alpha \varepsilon \lambda \alpha \rho \chi i \alpha$ " (principal flock of birds)

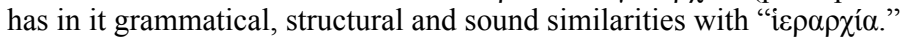

87 See $C H$ VII.2, Heil and Ritter 2012: 29.24; PG 3: 209a.

88 See $C H$ IV.3, Heil and Ritter 2012: 22.19; PG 3: 181a. Only in CH XI.2, Heil and Ritter 2012: 42.7-8; PG 3: 285a, does it not refer to God, but to the hierarchy in question, especially its order.

89 See $C H$ VIII.1, Heil and Ritter 2012: 33.22; PG 3: 240b.

90 In the same manner, due to being source of the characteristics of the angelic group

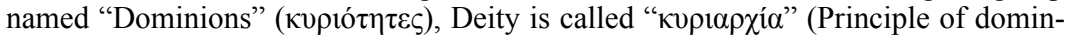
ion) in $\mathrm{CH}$ VIII.1, Heil and Ritter 2012: 33.4; PG 3: 237c.

91 See Ep. 9, 2, Heil and Ritter 2012: 200.5-8; PG 3: 1108d, Dodds 1963: prop. 65 and Vasilakis 2014: 210-212.

92 For the significance that Dionysius attaches to St John "the Divine," addressee of the last (10th) Epistle of $C D$, see Golitzin 2013: 1-6. See a complementary perspective in Vasilakis 2014: 247, n. 135 and Vasilakis 2017: 410, n. 13.

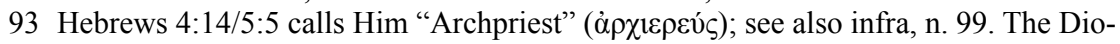
nysian passage to be cited has direct references to this Pauline text. Like with Dionysius I avoid calling its author pseudo-Paul; for this Epistle's authorship see Criswell 2013.

94 Dionysius, EH V.5, Heil and Ritter 2012: 112.8-15; PG 3: 512c-d. Cf. Hebrews 5:5-6 (my translation of the biblical excerpts).

95 Cf. $E H$ V.5, Heil and Ritter 2012: 107.16-17; PG 3: 505b. He is its principle, as already noted; cf. $E H$ I.1, Heil and Ritter 2012: 63.12-64.1; PG 3: 372a, and the full form in $E H$ I.2, Heil and Ritter 2012: 65.20-21; PG 3: 373b.

96 This could be an orthodox way towards understanding the supposedly infamous

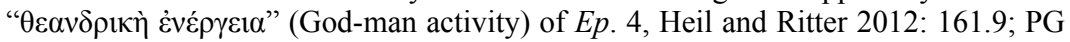
3: 1072c. See also the remarks by Golitzin 2013: 43-44.

97 Tsagdis unpublished makes many interesting connections with contemporary continental philosophy. Compare Dionysius' reception by Aquinas in Hankey 1997 and Hankey forthcoming, with the bibliography in $\mathrm{n} .1$.

98 There might be a word-play here between the terms hierarch and archpriest, since

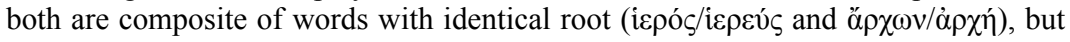
each time in the inverse order of composition.

99 So, also the hierarch functions as a specific image of Christ (cf. e.g. EH II.2, Heil and Ritter 2012: 70.2-3; PG 3: 393a) and both the angels and the theologians or hierarchs can be already called "gods" (cf. CH XII.3, 43.12-19; PG 3: 293b).

100 With regard to the hierarch see $C H$ XII.1, Heil and Ritter 2012: 42.15; PG 3: 292c; cf. EH VII.7, Heil and Ritter 2012: 127.16-18; PG 3: 561c, Mal 2:7, Rv e.g. 2:1 and 8. Regarding Christ see $C H$ IV.4, Heil and Ritter 2012: 24.1-4; PG 3: 181d. Cf. Isa 9:6.

101 See various examples in $C H$ VIII.2, Heil and Ritter 2012: 34.25-35.3; PG 3: 241a; CH XIII.3, Heil and Ritter 2012: 46.19-21; PG 3: 304b; CH XIII.4, Heil and Ritter 2012: 48.22-49.2; PG 3: 305c-d and ibid.: 49.8-10; PG 3: 308a.

102 For a philosophical approach to "angeletics," as has been termed, see Capurro and Holgate 2011, with a nice piece on Plotinus by Stamatellos 2011.

103 Perczel 2015: 218-219 notes that inserting between Paul and Dionysius the medium of another master, i.e. Hierotheus, is an "anomaly." Here we may consider 
that in the first sacrament to be described in $E H$ chapter 2, Baptism (or "divine

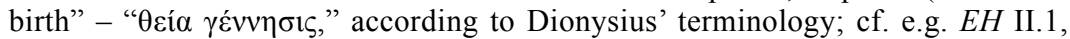
Heil and Ritter 2012: 69.7; PG 3: 392b, and Luibheid and Rorem 1987: 201, n. 21) we find this triple scheme again (especially ibid.: chapters 2 .II and III). The con-

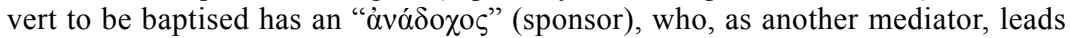
him, so to speak, to the Hierarch, symbolising the Church. This setting is an image of the hierarchy, when the person baptised is already a member, albeit the "lowest" one, of the Church. Yet again, the hierarch and generally the priestly order lead the way to God.

104 Cf. also CH XV.1, Heil and Ritter 2012: 50.13-51.1; PG 3: 328a, with Luibheid and Rorem 1987: 182, n. 126; 176, n. 116.

105 Thus, " $\varphi \imath \lambda o ́ \theta \varepsilon o v "$ (used only as adjective, not as noun, in the seven times it appears in $C D$ : cf. e.g. the ascription to Melchisedek in CH IX.3, Heil and Ritter 2012: 38.15 and 17; PG 3: 261a, mentioned supra) becomes the answer to God's " $\varphi 1 \lambda \alpha \nu \theta \rho \omega \pi i$ í." Note also that the supposed recipient of the main treatises of the Corpus $(D N / M T / C H / E H)$ is a priest called Timothy (Tupófos: the one who honours God, and therefore loves Him), like the recipient of two of Paul's Epistles (whose name has a resemblance with one of the main, even if absent, characters of the Symposium, Diotima: $\Delta$ totí $\mu \alpha$, i.e. the honour of Zeus).

\section{Bibliography}

\section{Primary sources}

\section{a. Editions}

Dodds, Eric R. (ed.) $\left(1963^{2}\right)$. Proclus, The Elements of Theology. Oxford: Clarendon Press. Heil, Günter and Ritter M. Adolf (eds.) (2012). Corpus Dionysiacum II. PTS. Vol. 67. Berlin/Boston: De Gruyter.

Saffrey, Henri-Dominique and Leendert G. Westerink (eds.) (1968-1997). Proclus, Théologie platonicienne. Vol. 6. Paris: Les Belles Lettres.

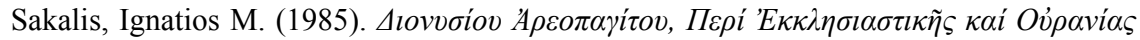

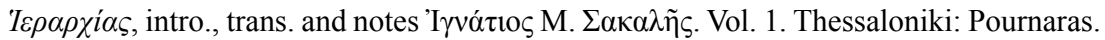

Suchla, Beate Regina (ed.) (1990). Corpus Dionysiacum I. Pseudo-Dionysius Areopagita, De Divinis Nominibus. PTS. Vol. 33. Berlin/New York: De Gruyter.

Westerink, Leendert G. (ed.) (1962²). Proclus, Commentary on the First Alcibiades. Amsterdam: North Holland Publishing.

\section{b. Translations}

Luibheid, Colm and Paul Rorem (1987). Pseudo-Dionysius: The Complete Works, trans. Colm Luibheid, foreword, notes and trans. collaboration by Paul Rorem, preface by René Roques, intro. Jaroslav Pelikan, Jean Leclercq, Karlfried Froehlich. New York/ Mahwah: Paulist Press.

\section{Scholarly literature}

Andreopoulos, Andreas (forthcoming). "A Defence for a Liturgical Reading of Dionysios the Areopagite." Studia Patristica. (The pagination in the references is that of the typescriptversion that was kindly sent to me). 
Arthur, Rosemary A. (2008). Pseudo-Dionysius as Polemicist: The Development and Purpose of the Angelic Hierarchy in Sixth Century Syria. London/New York: Routledge.

Biriukov, Dmitry (2015). "Hierarchies of Beings in Patristic Thought: Gregory of Nyssa and Dionysius the Areopagite." In The Ways of Byzantine Philosophy, ed. Mikonja Knežević, 71-88. Alhambra-California: Sebastian Press.

Bradshaw, David (2015). “The Divine Liturgy as Mystical Experience.” European Journal for Philosophy of Religion 7: 165-179.

Burns, Dylan (2004). "Proclus and the Theurgic Liturgy of Pseudo-Dionysius." Dionysius 22: 111-132.

Burnyeat, Myles F. (2012). “Aristotle on Understanding Knowledge.” In Explorations in Ancient and Modern Philosophy, ed. Myles F. Burnyeat. Vol. 2, 115-144. Cambridge: Cambridge University Press.

Capurro, Rafael and John Holgate (eds.) (2011). Messages and Messengers: Angeletics as an Approach to the Phenomenology of Communication. Munich: Wilhelm Fink.

Constas, Maximos (2017). "Maximus the Confessor, Dionysius the Areopagite, and the Transformation of Christian Neoplatonism." Analogia: The Pemptousia Journal for Theological Studies 2.1: 1-12.

Criswell, David (2013). Anonymous: Who Wrote the Epistle to the Hebrews? Dallas, TX: Fortress Adonai Press.

de Andia, Ysabel (1996). Henosis: L'union à Dieu chez Denys l'Aréopagite. Leiden/New York/Cologne: Brill.

(2006). "Pâtir les choses divines." In Denys l'Aréopagite. Tradition et metamorphoses, ed. Ysabel de Andia, 17-36. Paris: Vrin.

Drăgulin, Pr. Gheorghe I. (1979). "Eclesiologia tratatelor Areopagitice şi importanţa ei pentru ecumenismul contemporan (The Ecclesiology of the Areopagitic Treatises and Their Importance for Contemporary Ecumenism).” Doctoral thesis, Bucharest: Editura Institutului Biblic și de Misiune a Bisericii Ortodoxe Române.

Gavin, John S.J. (2008). "Maximus on the Incarnation as Key to Hierarchy in Church and Creation." Faith: Promoting a New Synthesis of Faith and Reason 40.6: 6a-10a.

Golitzin, Alexander (1994). Et introibo ad altare Dei: The Mystagogy of Dionysius Areopagita, with Special Reference to Its Predecessors in the Eastern Christian Tradition. Thessaloniki: Patriarchal Institute of Patristic Studies.

(2003). "Dionysius Areopagita: A Christian Mysticism?" Pro Ecclesia 12.2: $161-212$.

(2013). Mystagogy: A Monastic Reading of Dionysius Areopagita, ed. Bogdan G. Bucur. Collegeville, MN: Liturgical Press.

Hankey, Wayne (1997). "Dionysian Hierarchy in Thomas Aquinas: Tradition and Transformation." In Denys l'Aréopagite et sa postérité en Orient et en Occident. Actes du Colloque International Paris, 21-24 Septembre 1994, ed. Ysabel de Andia, 405-438. Paris: Institut d'Études Augustiniennes.

(forthcoming). "Providence and Hierarchy in Thomas Aquinas and the Neoplatonic Tradition." In The Question of Nobility: Aspects of Medieval and Renaissance Conceptualization of Man, ed. Andrea A. Robiglio. Leiden/New York: Brill.

Ivanovic, Filip (2011). "The Ecclesiology of Dionysius the Areopagite." International Journal for the Study of the Christian Church 11.1: 27-44.

(2017). "Union with and Likeness to God: Deification According to Dionysius the Areopagite." In Visions of God and Ideas on Deification in Patristic Thought, ed. Mark Edwards and Elena Ene D. Vasilescu, 118-157. London/New York: Routledge.

Knepper, Timothy D. (2014). Negating Negation: Against the Apophatic Abandonment of the Dionysian Corpus. Eugene, OR: Cascade Books. 
Kobusch, Theo (2017). “A New Way to God.” Studia Patristica 84.10: 157-164.

Lampe, Geoffrey W.H. (1961). A Patristic Greek Lexicon. Oxford: Clarendon Press.

Lossky, Vladimir (1930). "La notion des 'analogies' chez Denys le Pseudo-Aréopagite." Archives d'histoire doctrinale et littéraire du Moyen Age 5: 279-309.

- $\left(1968^{2}\right)$. The Mystical Theology of the Eastern Church, translated from French by members of the "Fellowship of St Alban and St Sergius." Cambridge: James Clarke and Co.

Loudovikos, Nicholas (2011). "Eikon and Mimesis Eucharistic Ecclesiology and the Ecclesial Ontology of Dialogical Reciprocity." International Journal for the Study of the Christian Church 11.2-3: 123-136.

Louth, Andrew (1981). The Origins of the Christian Mystical Tradition: From Plato to Denys. Oxford: Clarendon Press.

- (1986). "Pagan Theurgy and Christian Sacramentalism in Denys the Areopagite." The Journal of Theological Studies, New Series 37.2: 432-438.

- (1989). Denys the Areopagite. London/New York: Continuum.

Menelaou, Iakovos (2017). “An Analysis of Dionysius' Hierarchy in the Divine Names and His Other Works.” Journal of Religious Culture 228: 1-10.

Meyendorff, John (1980). "Review of Drăgulin 1979.” St. Vladimir's Theological Quarterly 24.1: 272.

Newheiser, David (2010). "Ambivalence in Dionysius the Areopagite: The Limitations of a Liturgical Reading.” Studia Patristica 48: 211-216.

O’Meara, Dominic J. (1975). Structures hiérarchiques dans la pensée de Plotin: Étude historique et interpretative. Leiden: Brill.

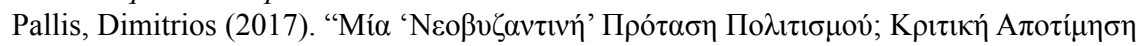
$\tau \eta \varsigma$ А

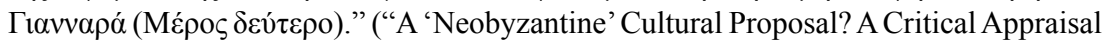
of the Assimilation of Areopagitic Apophaticism in the Early Thought of Christos Yannaras" [Part II]). Philosophein 16: 277-301.

Perczel, István (2015). "Dionysius the Areopagite." In The Wiley Blackwell Companion to Patristics, ed. Ken Parry, 211-225. Chichester, West Sussex: Wiley.

Perl, Eric D. (2007). Theophany: The Neoplatonic Philosophy of Dionysius the Areopagite. Albany, NY: State University of NY Press.

(2013). "Hierarchy and Love in St Dionysius the Areopagite." In Toward an Ecology of Transfiguration: Orthodox Christian Perspectives on Environment, Nature, and Creation, ed. John Chryssavgis and Bruce V. Foltz, 23-33. New York: Fordham University Press.

Rentel, Alexander (2006). "Byzantine and Slavic Orthodoxy." In The Oxford History of Christian Worship, ed. Geoffrey Wainwright and Karen W. Tucker, 254-306. Oxford: Oxford University Press.

Riggs, Timothy (2009). “Eros as Hierarchical Principle: A Re-Evaluation of Dionysius' Neoplatonism.” Dionysius 27: 71-96.

Rorem, Paul (2015). The Dionysian Mystical Theology. Minneapolis: Fortress Press.

Sophrony (Sakharov) (2016). Striving for Knowledge of God: Correspondence with David Balfour. Essex: Stavropegic Monastery of St John the Baptist.

Stamatellos, Giannis (2011). "Plotinus' Angeletics: A Neoplatonic Message Theory." In Messages and Messengers: Angeletics as an Approach to the Phenomenology of Communication, ed. Raphael Capurro and John Holgate, 125-134. Munich: Wilhelm Fink.

Stang, Charles M. (2012). "The Beginning and End of All Hierarchy." In The Open Body: Essays in Anglican Ecclesiology, ed. Zachary Guiliano and Charles M. Stang, 103-124. New York: Peter Lang. 
Stiglmayr, Josef (1898). "Über die Termini Hierarch und Hierarchie." Zeitschrift für Katholische Theologie 22.1: 180-187.

Stock, Wiebke-Marie (2008). Theurgisches Denken. Zur Kirchlichen Hierarchie des Dionysius Areopagita. Berlin/New York: Walter de Gruyter.

Terezis, Christos A. (2002). "Notizen zum Begriff 'Hierarchie' bei Proklos." Bochumer Philosophisches Jahrbuch für Antike und Mittelalter 7.1: 219-226.

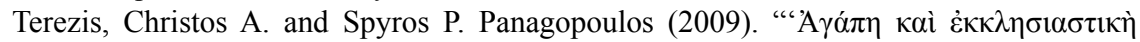

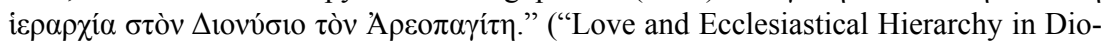

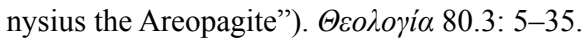

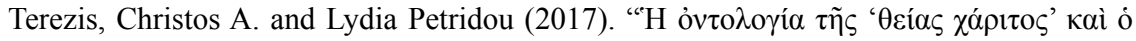

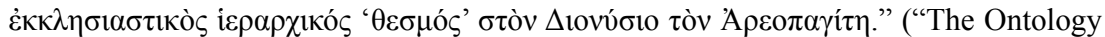
of the 'Divine Grace' and the Ecclesiastical Hierarchical 'Institution' in Dionysius the

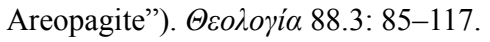

Tsagdis, Georgios (unpublished). "The Invention of Hierarchy in Pseudo-Dionysius." Read at the BSHP Annual Conference, 10/04/2015: York University.

Van den Berg, Robbert M. (2000). "Towards the Paternal Harbour: Proclean Theurgy and the Contemplation of the Forms." In Proclus et la Théologie Platonicienne. Actes du Colloque International de Louvain (13-16 Mai 1998). En l'honneur de H.-D. Saffrey et L.G. Westerink, ed. Alain-Philippe Segonds and Carlos Steel with the Help of Concetta Luna and A.F. Mettraux, 425-443. Leuven/Paris: Leuven University Press/Les Belles Lettres.

Vanneste, Jean S.I. (1959). Le Mystère de Dieu. Essai sur la structure rationelle de la doctrine mystique du Pseudo-Denys l'Aréopagite. Brussels: Desclée de Brouwer.

Vasilakis, Dimitrios A. (2014). "Neoplatonic Love: The Metaphysics of Eros in Plotinus, Proclus and the Pseudo-Dionysius.” Unpublished Ph.D. diss., London: King's College. (2017). "Dionysius versus Proclus on Undefiled Providence and Its Byzantine Echoes in Nicholas of Methone." Studia Patristica 96.22: 407-418.

Ware, Kallistos (2011). "Sobornost and Eucharistic Ecclesiology: Aleksei Khomiakov and His Successors." International Journal for the Study of the Christian Church 11.2-3: 216-235.

Wear, Sarah Klitenic and John Dillon (2007). Dionysius the Areopagite and the Neoplatonist Tradition: Despoiling the Hellenes. Aldershot/Burlington, VT: Ashgate.

Yannaras, Christos (2005). On the Absence and Unknowability of God: Heidegger and the Areopagite, trans. Haralambos Ventis, ed. and intro. Andrew Louth. London: T. and T. Clark. 
this represents an innovative attempt to leap over the logical constraints of the genus-species-individual relationship and establish commonality on a different metaphysical basis. And Maximus' originality consists in the identification of this metaphysical foundation with the Christian theory of the creation of the world.

\section{Notes}

* I would like to thank the editors for the kind invitation to contribute to this volume and for their precious feedback. I am also thankful to the series editors and the anonymous reviewers for their comments on my chapter, and to the audience of the International Workshop in Oslo on the Philosophy of Late Antiquity (December 2016) for a first reaction to my work.

1 For more on immanent realism, see Erismann 2011a.

2 See Zachhuber 2013: 425-470.

3 For a recent account of Maximus' life and work, see Allen and Neil 2015.

4 See, for instance, Erismann 2015 and Tollefsen 2015.

5 See Gerson 2004.

6 See Lloyd 1962.

7 Porphyry, Isag. 1.10-15; Barnes 2003: 3.

8 For Porphyry's theory of the "individual," see Chiaradonna 2000.

9 For further details, see Ammonius, In Porphyrii Isagogen 10-20.

10 See Lloyd 1981.

11 See Zachhuber 2013 and Erismann 2015.

12 I am indebted to Zachhuber 2013 for this section of the chapter.

13 Traditionally, that work figured among Basil's letters, but recent scholarship established its paternity in Gregory of Nyssa. See, for details, Zachhuber 2003.

14 Basil, Ep. 38.2.19-26; 1.82.

15 Basil, Ep. 214.4.9-15; 3.205; Zachhuber 2013: 437.

16 See, for instance, Zachhuber 2013: 428-436 on the Basil vs. Apollinarius debate over the idea that divine substance cannot be a pre-existent genus participated in by the divine persons.

17 "For species - and still more, genera - gather the many items into a single nature; whereas the individuals or singulars, in contrary fashion, always divide the one into a plurality. For by sharing in the species the many men are one man, and by the individuals the one and common man is several - for the singular is always divisive whereas the common is collective and unificatory" (Porphyry, Isag. 6, 19-25; Barnes 2003: 7).

18 Gregory of Nyssa, Ad Ablabium, GNO 3, t. 1, 40.24-41, 12; Zachhuber 2013: 446-447.

19 On this interpretation of Porphyry, see Lloyd 1990: 49-53.

20 For further details, see Erismann 2014a.

21 Gregory of Nyssa, Ad Ablabium, 53.7-15; Schaff 1886: 2.5, 335.

22 See Erismann 2008: 51-66.

23 In this respect, see Aristotle's definition of substance as an individual in the Categories: "that which is called a substance most strictly, primarily, and most of all - is that which is neither said of a subject nor in a subject, e.g. the individual man or the individual horse" (Aristotle, Cat. 2a13; Barnes 1984: 4).

24 Zachhuber 2013: 458-461.

25 For a comprehensive analysis of the theses of immanent realism, see Erismann 2011a.

26 For further details, see Grillmeier and Hainthaler 1995.

27 Lebon 1951: 425-580.

28 See Erismann 2011b: 81.

29 On Maximus' opposite view, which is supportive of the use of number "two" in Christology, see Mateiescu 2017b. 


\section{Sebastian Mateiescu}

30 See Mateiescu 2018.

31 On Philoponus' Tritheism, see Lang 2001.

32 For a similar account of Philoponus' use of philosophy in his theological arguments, see Erismann 2014b: 143-160.

33 Philoponus, Arbit. 21-22, Lang 2001: 191. For illustration, some Greek correspondents to some key concepts have been inserted as they were preserved in John of Damascus, Liber de haeresibus 5.52.

34 Philoponus, In Cat. 67, 31-34; Sirkel et al. 2015: 104.

35 Philoponus, In Cat. 58, 19-21. Sirkel et al. 2015: 95.

36 This does not mean that "man" is not irrational as well, but it is only meant to exclude the possibility that this property can describe the essence of "man".

37 Simplicius, In Cat. 83.1, 13-15; de Haas and Fleet 2001: 24.

38 However, Simplicius elsewhere (In Cat. 80, 1-10) seems to suggest the idea that what is immanent is still predicated of individuals in virtue of its "likeness to the transcendent [universal]."

39 See, for further details, Mateiescu 2018: 94-102 .

40 Philoponus, In Cat. 58, 19-21.

41 Philoponus, Arbit. 45, Lang 2001: 214.

42 For details, see Törönen 2007: 11-35, and Roueché 1980.

43 See, for instance, Maximus, Amb. Io. 16, 17 and 22.

44 Maximus, Ep. 12, PG 91: 469a-b. See also Törönen 2007: 89.

45 Porphyry, Isag. 3, 9-12.

46 Maximus, Amb. Th. 2, PG 91: 1037c-d.

47 Philoponus, Arbit. 32, Lang 2001: 199.

48 Maximus, Amb. Io. 7, PG 91: 1069b.

49 Maximus, $A m b$. Th. 5, PG 91: 1048a-b.

50 Maximus, $A m b$. Io. 10, PG 91: $1177 \mathrm{c}$.

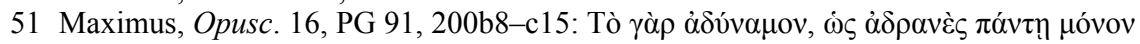

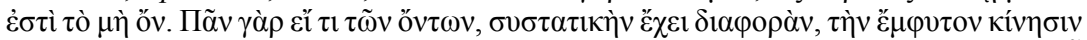

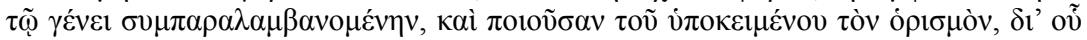

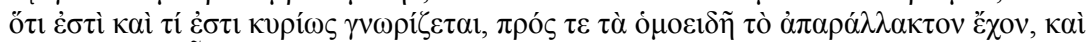

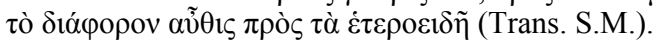

52 As noted by an anonymous reviewer for this chapter, Maximus' approach here is tantamount to imposing an ontological and immanent taxonomical order, rather than constructing the argument from logical grounds. This method, however, has the virtue of showing us how key terms in logic (e.g. differentia) are metaphysically laden and how this, in itself, has the force to lead to different logical conclusions. In Maximus' view reported in this paper, this logical side of the argument corresponds to predicating existence "in" two natures about Christ.

53 Maximus, Amb. Th. 5, PG 91: 1048a-b; Constas 2014: 33.

54 Idem.

55 Maximus, Amb. Io. 41, PG 91: 1312c-e.

56 Maximus, Amb. Io. 41, PG 91: 1312c-d.

57 Maximus, Amb. Th. 5, PG 91:1049c-d.

58 Maximus, Amb. Th. 5, PG 91: 1048a-b; Constas 2014: 33

59 On the importance of Dionysius to Maximus' thought, see Louth 2006: 19-33.

60 Dionysius, EH II.1, Heil and Ritter 2012: 69.9-12; PG 3: 392b; Parker 1897: 54.

61 Plato, Soph. 247d8-e4.

62 See, for details, Beere 2009: 33-64.

63 As the series editors have rightly commented on an earlier draft of this chapter, there have been eventually many other channels (such as possibly Iamblichus with the traid being-dunamis-mind or Proclus' with being-life-mind) through which the philosophical account of dunamis has influenced the Christian thought. For an overview of dunamis in several such Neoplatonic contexts, which includes Dionysius, see Romano and Cardullo 1996. As concerns their echo in Maximus, see more recently 
Lauritzen 2012 who (unconvincingly, in my opinion) connects Maximus' view of energeia with that of Proclus. Rather, it seems that Plotinus' theory of the nous as being "in actuality all particular intellects and potentially each of them" (Enn. 6.2.20), an argument that bears important relevance for the issue of universals viz. genus and species (see Lloyd 1956) anticipates well Maximus' theory of immanent realism as based on differentia as dunamis. Certainly, further work is needed in this direction, which needs to move beyond the quest for terminological similarities between Neoplatonic concepts and Christian notions into a more comprehensive analysis in terms of the rationale and argumentative strategy for their employment.

64 Maximus, Ep. 12, PG 91: 473c-d.

65 See, for instance, Beere 2009: 294.

66 Maximus, Amb. Th. 5, PG 91: 1052c; Constas 2014: 43.

67 Maximus, Amb. Io. 20, PG 91: 1237b; Constas 2014: 411 (translation modified).

68 Maximus, Opusc. 1, PG 91, 33b7-12.

69 Maximus, Amb. Io. 41, PG 91: 1312c.

70 On the principle of traditional logic that the differentia must come "from outside" the genus, see Lloyd 1962.

71 Maximus, Ep. 13, PG 91: 517a-d. See, for further details, Mateiescu 2017a.

\section{Bibliography}

\section{Primary sources}

\section{a. Editions}

Busse, Adolfus (ed.) (1891). Ammonii In Porphyrii Isagogen sive V Voces. CAG. Berlin: Reimer.

(ed.) (1898). Philoponi in Aristotelis Categorias Commentarium. CAG. Berlin: Reimer.

Constas, Nicholas (ed. and trans.) (2014). Maximos the Confessor, on Difficulties in the Church Fathers: The Ambigua. Vols. 1 and 2. Dumbarton Oaks Medieval Library 28-29. Cambridge, MA: Harvard University Press.

Courtonne, Yves (ed. and trans.) (1957-1961). Basile de Césarée, Correspondance. Tome 1-3. Paris: Les Belles Lettres.

Heil, Günter and Adolf M. Ritter (eds.) (2012). Corpus Dionysiacum II. Berlin/Boston: De Gruyter.

Kotter, Bonifatius (ed.) (1981). Die Schriften des Johannes von Damaskos IV. Liber de Haeresibus: Opera Polemica. Berlin: De Gruyter.

Migne, Jacques-Paul (ed.) (1857-1866). Maximi Confessoris Opera Omnia. PG. Vols. 90-91. Paris: Imprimerie Catholique.

\section{b. Translations}

Barnes, Jonathan (ed.) (1984). The Complete Works of Aristotle I-II. Princeton: Princeton University Press.

- (2003). Porphyry, Introduction, translation and commentary Jonathan Barnes. Oxford: Clarendon Press.

Cooper, John M. (ed.) (1997). Plato, Complete Works. Indianapolis: Hackett.

Haas, Frans A. J. and Barrie Fleet (trans.) (2001). Simplicius, On Aristotle's Categories 5-6. Ithaca: Cornell University Press.

Lang, Uwe Michael (2001). John Philoponus and the Controversies over Chalcedon in the Sixth Century: A Study and Translation of the Arbiter. Leuven: Peeters. 


\section{Sebastian Mateiescu}

Parker, John (trans.) (1897). The Works of Dionysius the Areopagite. Oxford: James Parker and Co.

Schaff, Philip (ed.) (1886-1890). A Select Library of the Nicene and Post-Nicene Fathers of the Christian Church. Buffalo: The Christian Literature Co.

Sirkel, Riin, Martin Tweedale and John Harris (trans.) (2015). Philoponus, on Aristotle Categories 1-5. London/New York: Bloomsbury.

\section{Scholarly literature}

Allen, Pauline and Bronwen Neil (eds.) (2015). The Oxford Handbook of Maximus the Confessor. Oxford: Oxford University Press.

Beere, Jonathan (2009). Doing and Being: An Interpretation of Aristotle's Metaphysics Theta. Cambridge: Cambridge University Press.

Chiaradonna, Riccardo (2000). "La Teoria dell'individuo in Porfirio e l'I $\Delta \mathrm{I} \Omega \Sigma$ ПOION Stoico." Elenchos 21: 303-331.

Erismann, Christophe (2008). "L'individualité expliquée par les accidents: remarques sur la Destinée 'chrétienne' de Porphyre." In Compléments de Substance: Études sur les propriétés accidentelles offertes à Alain de Libera, ed. Christophe Erismann and Alexandrine Schniewind, 5166. Paris: Vrin.

(2011a). L'Homme Commun: La genèse du réalisme ontologique durant le haut Moyen Âge. Paris: Vrin.

(2011b). "Non est natura sine persona: The Issue of Uninstantiated Universals from Late Antiquity to the Early Middle Ages." In Methods and Methodologies: Aristotelian Logic East and West, 500-1500. Investigating Medieval Philosophy 2, ed. Margaret Cameron and John Marenbon, 75-91. Leiden/Boston: Brill.

(2014a). "Catachrestic Plural Forms: Gregory of Nyssa and Theodore Abū Qurrah on Naming and Counting Essences." British Journal for the History of Philosophy 22.1: $39-59$.

(2014b). "John Philoponus on Individuality and Particularity." In Individuality in Late Antiquity, ed. Alexis Torrance and Johannes Zachhuber, 143-160. Farnham: Ashgate Publishing.

(2015). "Maximus the Confessor on the Logical Dimension of the Structure of Reality." In The Architecture of the Cosmos: St Maximus the Confessor: New Perspectives, ed. Antoine Lévy OP, Pauli Annala, Olli Hallamaa and Tuomo Lankila, with the collaboration of Diane Kaley, 51-70. Helsinki: Luther Agricola Society.

Gerson, Lloyd P. (2004). "Platonism and the Invention of the Problem of Universals." Archiv für Geschichte der Philosophie 86: 233-256.

Grillmeier, Alois and Theresia Hainthaler (1995). Christ in Christian Tradition, Vol. 2, Part 2, the Church of Constantinople in the Sixth Century. London: Mowbrays/Louisville, KY: Westminster John Knox.

Lauritzen, Frederick (2012). "Pagan Energies in Maximus the Confessor." Greek, Roman, and Byzantine Studies 52: 226-239.

Lebon, Joseph (1951). "La Christologie du monophysisme Syrien.” In Das Konzil von Chalkedon, ed. Alois Grillmeier and Heinrich Bacht 3 vols., 425-580. Würzburg: Echter Verlag.

Lloyd, Anthony C. (1956). "Neo-Platonic Logic and Aristotelian Logic II." Phronesis 1.2: 146-160.

(1962). "Genus, Species and Ordered Series in Aristotle." Phronesis 7.1: 67-90.

(1981). Form and Universal in Aristotle. Liverpool: Francis Cairns. 
(1990). The Anatomy of Neoplatonism. Oxford: Clarendon Press.

Louth, Andrew (2006). Maximus the Confessor. London/New York: Routledge.

Mateiescu, Sebastian (2017a). “Union without Confusion': Nemesius of Emesa and Maximus the Confessor on the Christological Implications of the Relationship between Soul and Body." Analogia: The Pemptousia Journal for Theological Studies 2.1: $125-139$.

(2017b). "Counting Natures and Hypostases: St Maximus the Confessor on the Role of Number in Christology." Studia Patristica 89: 63-79.

(2018). "John Philoponus and the Interpretation of the Differentia in the Aftermath of Chalcedon.” In Aristotle in Byzantium, ed. Mikonja Knežević. Los Angeles, CA: Sebastian Press/Podgorica: Center for Hellenic Studies, 83-123.

Romano, Francesco and Loredana R. Cardullo (eds.) (1996). Dunamis nel neoplatonismo: atti del II colloquio internazionale del Centro di ricerca sul neoplatonismo, Università degli studi di Catania, 6-8 ottobre 1994. Firenze: La nuova Italia.

Roueché, Mossman (1980). "A Middle Byzantine Handbook of Logic Terminology.” Jahrbuch der Österreichischen Byzantinistik 29: 71-98.

Tollefsen, Torstein T. (2015). "The Concept of the Universal in the Philosophy of St Maximus." In Architecture of the Cosmos: St Maximus the Confessor: New Perspectives, ed. Antoine Lévy OP, Pauli Annala, Olli Hallamaa and Tuomo Lankila, with the collaboration of Diane Kaley, 70-93. Helsinki: Luther Agricola Society.

Törönen, Melchisedec (2007). Union and Distinction in the Thought of St Maximus the Confessor. Oxford: Oxford University Press.

Zachhuber, Johannes (2003). "Nochmals: Der '38. Brief” des Basilius von Cäsarea als Werk des Gregor von Nyssa." ZAC: 73-90.

(2013). "Universals in the Greek Church Fathers." In Universals in Ancient Philosophy, ed. Ricardo Chiaradonna and Gabriele Galluzzo, 425-470. Pisa: Edizioni Della Normale. 
We can enjoy an identity with God that exceeds participation only because God himself is more than a mere essence or energy. Christ revealed as much in person. His ecstasy as and into us invites ours as and into him. As the Apostle said, we shall become "one flesh" (Col 1:18; Eph 5:30-31). ${ }^{75}$

\section{Conclusion}

I have sought to demonstrate that and how the logics of perichōrēsis and Neoplatonic participation differ. perichōeessis's trinitarian origins brand it with three crucial marks: [1] there is an ineffable identity of two entities; [2] the two thus identified penetrate each other completely; [3] and yet even in this actual interpenetration they preserve their respective modal integrities perfectly intact. The Christological application adds a fourth, more stunning feature: [4] that the three prior marks can characterise even a vertical perichōrēsis between naturally superior and inferior modes of existence. That Maximus dares apply vertical perichōrēsis to the creature's deified state - its full return to God - shows that he does not think its logic confined to the Christ event but rather indicative of the God-world relation itself.

Whether this view evacuates the historical Incarnation of its primacy, or on the contrary proves that event so primary that it can incorporate the very particularity of all events remains an open question for systematic and philosophical theology. Less open, I think, is the exegetical observation that Maximus conceives perichoretic logic as surpassing (and thus not simply negating) the logic of Neoplatonic participation, and that he envisions the former as ultimately governing the latter. How and why he might have come to such a conviction what, I mean, were the precise influences and historical circumstances that could have occasioned such a profound view of the God-world relation - I leave for another study.

\section{Notes}

1 Von Balthasar 2003: 15-18.

2 Sherwood 1964: 435-436.

3 Perl 1991: esp. ch. 6; Tollefsen 2008 and 2012.

4 Lévy 2006, for instance.

5 Portaru 2012.

6 Larchet 1996: 600-602; Tollefsen 2001 criticises Larchet, but does not to my mind add much more than what Larchet himself already admitted, namely that participation stresses "la distance qui subsiste entre la nature de l'homme divinisé et la nature divine elle-même" (600).

7 So Portaru 2012: 296, offers this working definition: "the relation between the One and the many, existence and its principle and how the connection between them is made. This is, I think, the most general and open philosophical understanding of participation."

8 Portaru 2012: 317.

9 So Siorvanes 1996: 72: "participation ( $\mu \varepsilon \varepsilon \varepsilon \xi \xi \varsigma)$ emphasises that an inferior cannot possess a superior entire"; see too infra, "Christological application."

10 Origen, Princ. 1.3.3-4, 1.4.4-5, 2.9.2, 4.4.1. 
11 Balás 1975: 263, notes that Origen conceives the Son as receiving all from the Father by participation, and yet, because the Son's attributes are the Father's own (e.g.

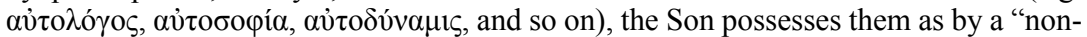
participated possession."

12 Origen, Comm. in Io. 2.17, GCS IV: 54.

13 Origen, Comm. in Io. 2.18, GCS IV: 54, Heine 1989: 99. Here Origen proves similar to later Neoplatonists like Proclus, who also wavers over the exact relation between the second and highest levels of entities. Proclus, El. theol. prop. 114, denies that his henads (=the gods) "participate" the One, though they are hypostatically distinct from It (i.e. they are self-subsistent).

14 Balás 1975: 265, who provides Justinian's subordinationist-tinged rendering of Princ. 1.3.8.

15 Gregory of Nazianzus, Oratio 31.14. Even Evagrius of Pontus (d. 399), whose legacy would later suffer from its Origenist leanings, makes sure to deny that the Son is either "like" or "unlike" the Father - for either implies a difference in quality, and that a difference in nature; cf. his On the Faith 9.

16 Basil the Great, Ep. 214, PG 32: 789a-b; so too at Amb. Io. 23.4.

17 See Zachhuber 2015 on the tensions in this Cappadocian "classical theory," especially in Gregory of Nyssa.

18 Harrison 1991: 59-60; cf. Ps.-Cyril, De Sacrosancta Trinitate 10, PG 77: 1144b, and John of Damascus, De fide orthodoxa 1.8 .

19 Maximus, Amb. Th. 1.3, modified.

20 Maximus, Ep. 15, PG 91: 549c-d.

21 Maximus, Amb. Th. 1.3, modified.

22 Maximus, Car. 2.29, Sherwood 1955: 158.

23 Maximus, Car. 2.29, Sherwood 1955: 158.

24 Maximus, Th. oec. 2.1, Salés 2015: 106-107.

25 Maximus, $Q$. Thal. 8.

26 Cf. Maximus, Amb. Io. 10.39, Amb. Io. 67.10, Q. Thal. 28.5.

27 Maximus, Or. dom. 2, CCSG 23: 31-32.

28 Maximus, Or. dom. 4, CCSG 23: 40-41.

29 Maximus, Or. dom. 4, CCSG 23: 54.

30 Maximus, Or. dom. 4, CCSG 23: 52 (and 54): "[The Jewish error] does not see what God would be if he had no part with the Word and Spirit, nor how he would be God in having part with them as if they were accidents, by a participation close to that of

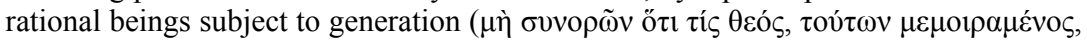

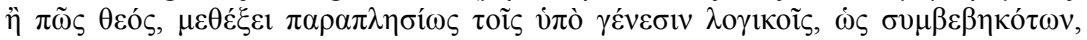

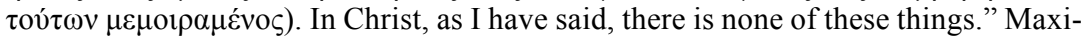
mus here combines two kinds of "participation" into one error - the more vertical variety (Reason participated by rational beings) and the more horizontal (accidents participating in a subject). It is tempting to label these as (Neo)Platonic and Aristotelian, respectively.

31 Dionysius, Ep. $4=A m b . T h .5 .1$.

32 Maximus, Amb. Th. 4.8, 5.24, passim.

33 So Maximus, Ep. 15; PG 91: 552c, which says hypostatic identity establishes "mutual

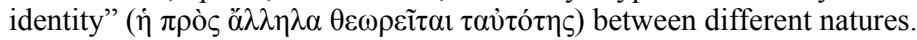

34 Maximus, $A m b$. Th. 5.11, modified.

35 On how the monenergist answer naturally arose from emphases in Neochalcedonian Christology itself (of which Maximus was partisan), see Uthemann 1997: 408.

36 Maximus, Opusc. 5, PG 91: 64a-65a, my translation.

37 An important inspiration for Maximus derives, of course, from the Christological use of the term at Gregory of Nazianzus, Epistle 101, SC 208: 48 (translation from Harrison 1991: 55, slightly modified): "Just as the natures are mixed, so also the names pass reciprocally $(\pi \varepsilon \rho \iota \omega \rho \circ v \sigma \tilde{\nu} v)$ into each other by the principle of natural co-affinity 


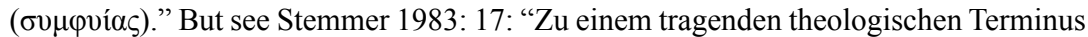
wird $\pi \varepsilon \rho \iota \omega \rho \varepsilon \tilde{v} v$ erst bei Maximus Confessor im 7. Jahrhundert."

38 Cf. Maximus, Car. 3.29, Ceresa-Gastaldo 156-158, where Maximus faults Greek philosophy precisely for conceiving creation as the variegated modal (qualitative) permutation of a single essence. Maximus's critique is not just metaphysical but Christological.

39 A subtle point Maximus makes, for instance, before Pyrrhus, who was himself quite stunned by it: "PYRRHUS: There is nothing, then, which the natures and natural properties have in common [Koเvóv]? MAXIMUS: Nothing, save only the hypostasis of these same natures. For, just in this way a hypostasis was the very same, unconfusedly,

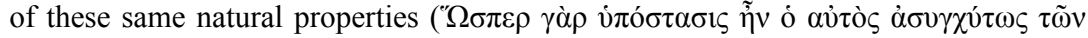

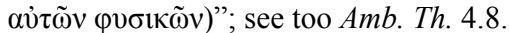

40 Wood 2018: 87-89.

41 It is not as if "the Son" or "Paul" or any person qua person bears natural qualities. A person (or hypostasis) as such possesses such qualities in whatever nature it bears, but cannot be reduced to them (Amb. Io. 17.5). If, then, a hypostasis is a positive reality that is not reducible to nature (its power, mode, properties, acts - in a word, its $\log o s$ ), then it need not impinge upon any aspect of nature when it instantiates it. So when Christ instantiates both created and uncreated natures in his very person, the concrete positivity he $i s$ need not in any way qualify either nature as such. Indeed the very fact that his hypostasis is both and yet diminishes neither is the concrete condition for the possibility of their total, real, undiminished preservation as identical to one another.

42 Dionysius, Ep. 4.

43 Maximus, $A m b$. Th. 5.17, slightly modified.

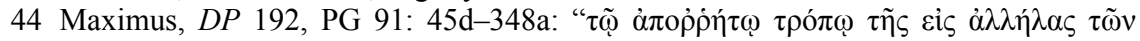

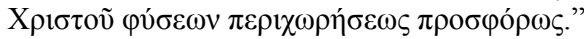

45 Maximus, $A m b$. Th. 5.14, slightly modified.

46 E.g. Stemmer 1983: 10-14.

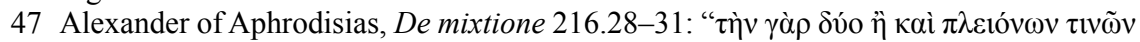

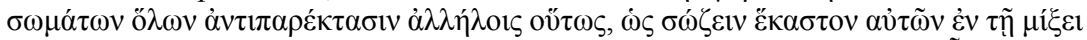

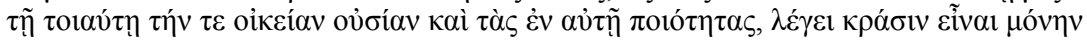
$\tau \tilde{\omega} \nu \mu i \xi \varepsilon \varepsilon \omega . "$

48 Proclus, In Parm., Cousin 754, and El. theol. prop. 176 (on intellectual forms in Intel-

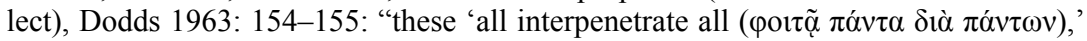

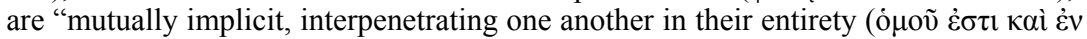

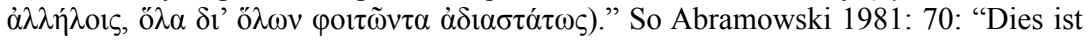
also die 'geziemende' Weise, von Einheit auf der Ebene des Geistigen zu sprechen."

49 Plato himself had registered this possibility as a marvel quite beyond participation's reach; cf. Parm. $129 \mathrm{~b}-\mathrm{c}$.

50 Gersh 1978: 27-44.

51 Plato, Parm. 131b-c (the problem of the Sail Cloth); Plotinus, Enn. VI.4-5 (basically a commentary on the Parm., on the One's undiminished omnipresence to all things, even to body). Cf. the very useful introduction to Enn. VI.4-5, in Emilsson and Strange 2015: 17-44, and Lloyd 1998: 98-110.

52 Proclus, El. theol. prop. 2; Dodds 1963: 3.

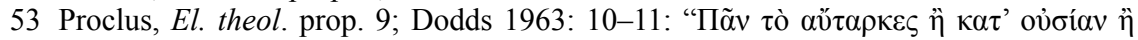

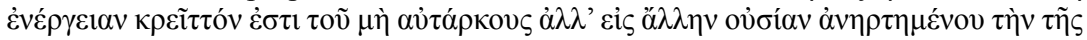
$\tau \varepsilon \lambda \varepsilon i o ́ \tau \eta \tau o \zeta \alpha i \tau i ́ \alpha . "$

54 Proclus, El. theol. prop. 18, Dodds 1963: 20-21. So arises Proclus's famous three

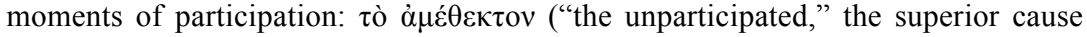
in its proper mode), $\tau$ ò $\mu \varepsilon \tau \varepsilon \chi o ́ \mu \varepsilon v o v$ ("the participated," the whole presence of the superior cause in the effect according to the effect's proper mode), $\tau$ ò $\mu \varepsilon \tau \varepsilon \dot{\varepsilon} \chi 0 v$ ("the participating," the effect qua distinct/proceeded from what it has identical to its 
superior cause); cf. Proclus, El. theol. props. 23-24, Dodds 1963: 26-29. Cf. too Gersh 1978: 150-151, for the necessary "vertical" and "horizontal" orders of existence (hypostases).

55 Proclus, El. theol. props. 75, 77, 78; cf. Iamblichus, De myst. I.18; Dionysius, DN 5.2. I refer here to an idea already developed in Plotinus, that vertical causation consists in the limitation of a higher, interior act by (or in the mode of) a lower power. See Gurtler 2009.

56 Iamblichus, De myst. I.19 Proclus, El. theol., props. 66-74.

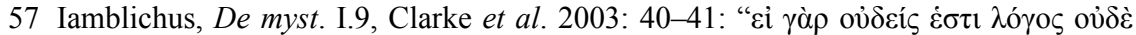

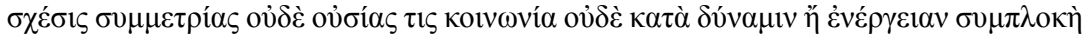

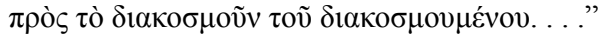

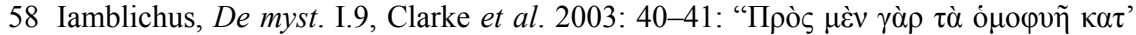

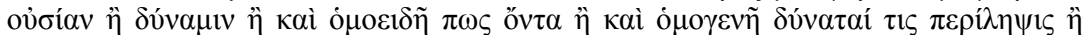

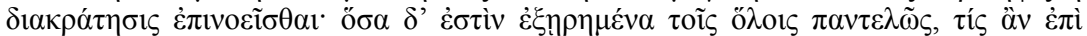

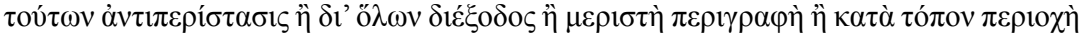

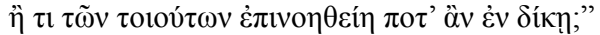

59 Dionysius, DN 2.6; Suchla 1990: 130.

60 So Garrigues 1982: 178-179.

61 Maximus, Amb. Io. 7.12.

62 Maximus, Amb. Io. 7. 22. See Thunberg 1995: 32-33, and Larchet 1996: 376-382.

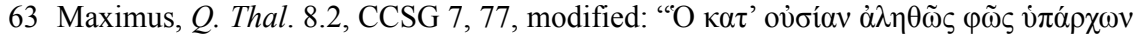

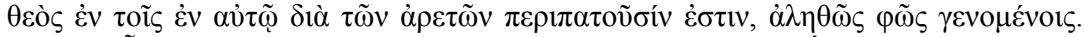

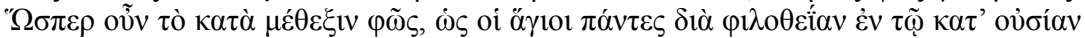

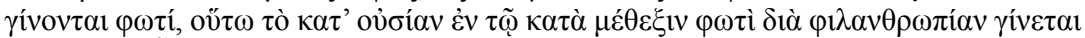

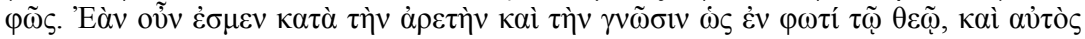

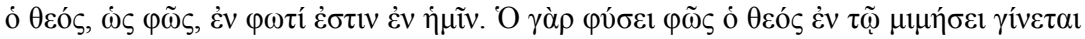

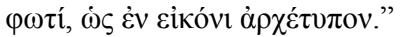

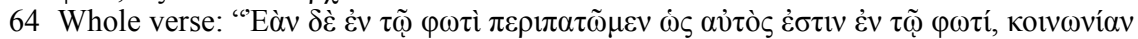

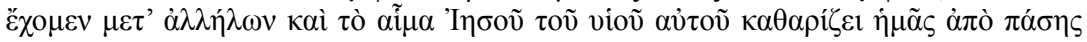

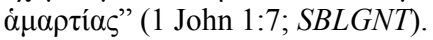

65 Maximus, Amb. Io. 41.5; Amb. Io. 48.7; Amb. Io. 53.3; Q. Thal. 40.8.

66 Nor is it, say, an abbreviated version of Proclus's unparticipated-participableparticipated triad (cf. El. theol. props. 23-24), for at least two reasons. The first and most obvious is that those technical terms do not appear in this passage. But second and more importantly, the logic does not either, since for Proclus the "unparticipated" term is precisely what is not in the participated because it is "prior to the many" (prop.

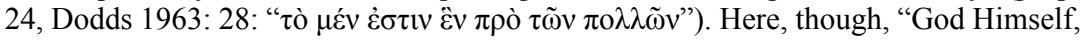
as light, is in us who are light." It is true that we never become identical to the divine essence (cf. infra, n. 73), but the Christian God is not simply an essence. This God is rather an essence that is tri-hypostatic, so that the second hypostasis can himself be the non-natural mediator of the divine essence to those who are essentially not God. A better candidate for Maximus's potential use of Proclus's triad is Th. oec. 1.49, PG 90, 1101 (and really 1.48-50 as a whole), but see the careful qualifications of Greig 2017: 144-147, esp. the suggestion that Maximus's "eternal works," which are not selfsubsistent like Proclus's participated terms, could "constitute a new ontological category for participated entities" $(148, \mathrm{n}$. 26). In other words, the transition from the cause's transcendent power (as unparticipated) to the effect's immanent power (as participated by the participant) does not operate as Proclus's triad must, even if the triadic structure itself persists in Maximus. That makes sense if the transition - indeed the procession comes through a divine hypostasis rather than a higher nature's modal limitation.

67 Gen 1:26-27. So Clement of Alexandria, Pr. 9.87; Evagrius, Letter to Melania 62, Letter to Anatolius 18.61; Diadochus of Photice, De perfectione spirituali 89, PG 65, $1203 \mathrm{c}-\mathrm{d}$ (Latin). 
68 Maximus, Car. 3.25; Amb. Io. 7.21; cf. Q. Thal. 53.3 and 6.

69 Maximus, Amb. Io. 21.15, PG 91: 1253d, my modifications and emphasis: "Tò $\delta \dot{\varepsilon}$

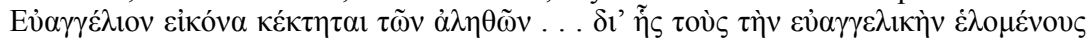

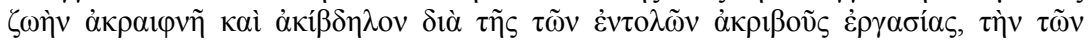

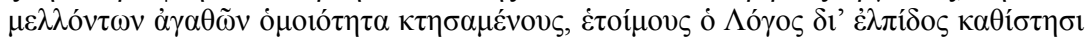

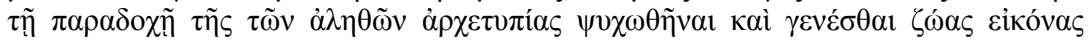

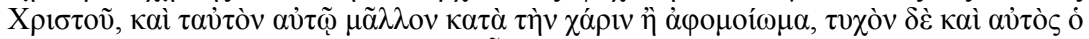

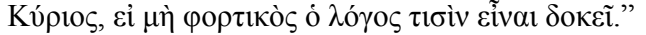

70 Aristotle, Pol. 1453b11, for instance, which Ayroulet also correlates with the metaphysics of first and second ousia at Cat. 2a 11-23; so Ayroulet 2013: 42: "Dans le platonisme, les Idées archétypales existent en soi et précèdent dans l'existence les images qui en sont les copies, que ce soit dans le monde sensible ou dans l'art qui imite le sensible. Chez Aristote, au contraire, il semble que le prototype n'existe pas en tant que les mais seulement dans la $\mu$ í $\eta$ $\sigma \varsigma \varsigma$ actualisée dans l'image." He says Aristotle's view implies "une simultanéité existentielle entre le modèle et l'image" (77), and applies this insight to Maximus later $(148,296)$.

71 Dionysius, EH 1.3, Heil and Ritter 1991: 66, 11.12-13, my translation: "i $\delta \dot{\varepsilon} \theta \dot{\varepsilon} \omega \sigma 1 \varsigma$

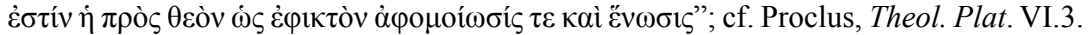

72 Maximus, Myst. 24, CCSG 69, 58; Q. Thal. 59.8, CCSG 22, 53; Q. Thal. 25.5; Amb. Io. 41.5, passim.

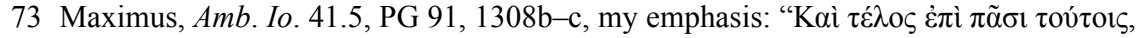

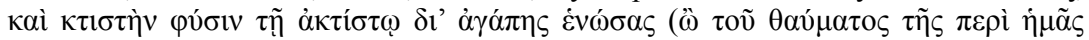

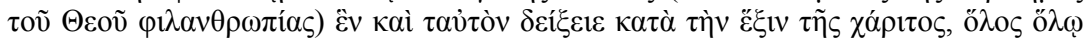

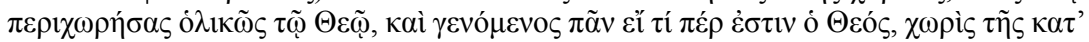

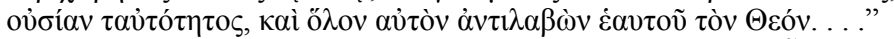

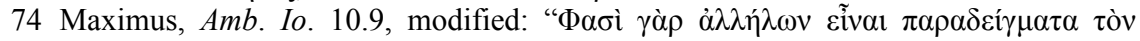

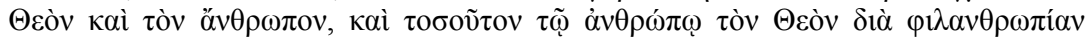

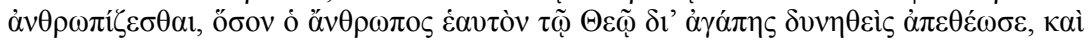

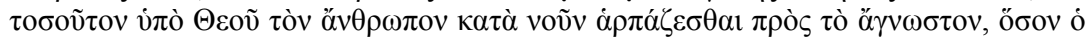

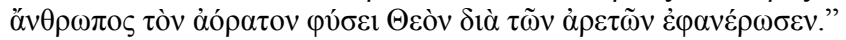

75 Maximus, Myst. 24, CCSG 69, 59-60.

\section{Bibliography}

\section{Primary sources}

\section{a. Editions}

Armstrong, Arthur H. (ed. and trans.) (1987). Plotinus, Ennead VI. LCL. Vol. 445. Cambridge, MA: Harvard University Press.

Boudignon, Christian (ed.) (2011). Mystagogia. CCSG. Vol. 69. Turnhout: Brepols.

Ceresa-Gastaldo, Aldo (ed.) (1963). Massimo Confessore: Capitoli sulla Carità. Verba seniorum. Vol. 3. Rome: Editrice Studium.

Constas, Nicholas (ed. and trans.) (2014). Maximos the Confessor, on Difficulties in the Church Fathers: The Ambigua. Vols. 1 and 2. Dumbarton Oaks Medieval Library 28-29. Cambridge, MA: Harvard University Press.

Cooke, Harold P. (trans.) (1938). Aristotle: The Organon. LCL. Vol. 1. Cambridge, MA: Harvard University Press.

Dodds, Eric R. (ed. and trans.) (1963). The Elements of Theology. 2nd edition. Oxford: Oxford University Press. 


\section{Jordan Daniel Wood}

Cousin, Victor (ed.) (1864). "Procli Commentarium in Platonis Parmenidem." In Procli Opera Inedita. Paris: Durand.

Görgemanns, Herwig and Heinrich Karpp (eds.) (1992). Origenes Vier Bücher von den Prinzipien. Texte zur Forschung. Vol. 24. Darmstadt: Wissenschaftliche Buchgesellschaft.

Heil, Günther and Adolf Martin Ritter (eds.) (1991). Corpus Dionysiacum II. PseudoDionysius Areopagita, De Coelesti hierarchia, De ecclesiastica hierarchia, De mystica theologia, Epistulae. PTS. Vol. 36. Berlin/Boston: De Gruyter.

Jourjon, Maurice (ed.) (1974). Lettres théologiques [de] Grégoire de Nazianze. SC. Vol. 208. Paris: Le Cerf.

Kotter, Bonifatius (ed.) (1969-1988). Die Schriften des Johannes von Damaskos. PTS. Vol. 17. Berlin: De Gruyter.

Laga, Carlos and Carlos Steel (eds.) (1980). Quaestiones ad Thalassium I. CCSG. Vol. 7. Turnhout: Brepols. (1990). Quaestiones ad Thalassium II. CCSG. Vol. 22. Turnhout: Brepols.

Marcovich, Miroslav (ed.) (1995). Clementis Alexandrini Protrepticus. Leiden: Brill.

Migne, Jacques-Paul (ed.) (1875). Opera Omnia. Patrologiae cursus completus, seu Bibliotheca universalis, integra, uniformis, commoda, oeconomica omnium SS patrum, doctorum scriptorumque ecclesiasticorum: Series Graeca. Vols. 65, 77, 90-91. Paris: Imprimerie Catholique.

Suchla, Beate Regina (ed.) (1990). Corpus Dionysiacum. PTS. Vols. 33, 36, and 62. Berlin/ Boston: De Gruyter.

Todd, Robert B. (ed.) (1976). Alexander of Aphrodisias on Stoic Physics: A Study of the De Mixtione with Preliminary Essays, Text, Translation and Commentary. Philosophia antiqua. Vol. 28. Leiden: Brill.

Van Deun, Peter (ed.) (1991). Opuscula exegetica duo [Expositio in Psalmum LIX. Expositio orationis dominicae]. CCSG. Vol. 23. Turnhout: Brepols.

\section{b. Translations}

Berthold, George C. (trans.) (1985). Selected Writings. Classics of Western Spirituality, intro. Jaroslav Pelikan. Mahwah: Paulist Press.

Casiday, Augustine M. (trans.) (2006). “On the Faith.” In Evagrius Ponticus. New York, NY: Routledge.

Clarke, Emma C., John M. Dillon and Jackson P. Hershbell (eds. and trans.) (2003). Iamblichus: On the Mysteries. Atlanta, GA: Society of Biblical Literature.

Constas, Fr. Maximos (trans.) (2018). On Difficulties in Sacred Scripture: Responses to Thalassios. Fathers of the Church. Vol. 136. Washington, DC: Catholic University of America Press.

Emilsson, Eyjólfur Kjalar and Steven Keith Strange (eds. and trans.) (2015). Plotinus, Ennead VI.4 and VI.5: On the Presence of Being, One and the Same, Everywhere as a Whole. Las Vegas/Zurich/Athens: Parmenides Publishing.

Heine, Ronald (trans.) (1989). Origen: Commentary on the Gospel According to John, Books 1-10. Fathers of the Church. Vol. 80. Washington, DC: Catholic University of America Press.

Hermann, Arnold and Sylvana Chrysakopoulou (trans.) (2010). Plato's Parmenides: Text, Translation and Introductory Essay. Las Vegas/Zurich/Athens: Parmenides Publishing.

Parmentier, Martin. (1985). "Evagrius of Pontus 'Letter to Melania' I." Bijdragen, tijdschrift voor filosofie en theologie 46: 2-38. 
Salés, Luis (trans.) (2015). Two Hundred Chapters on Theology: St. Maximus the Confessor. Popular Patristics Series. Vol. 53. Yonkers, NY: St. Vladimir's Seminary Press.

Sherwood, Polycarp O.S.B. (trans.) (1955). St. Maximus the Confessor: The Ascetic Life, the Four Centuries on Charity. Ancient Christian Writers. Vol. 21. New York, NY: The Newman Press.

Williams, Frederick and Lionel Wickham (trans.) (2002). St. Gregory of Nazianzus: On God and Christ: The Five Theological Orations and Two Letters to Cledonius. Popular Patristics Series. Vol. 23. Crestwood, NY: St. Vladimir's Seminary Press.

\section{Scholarly literature}

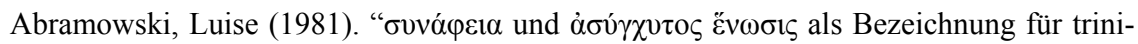
tarische und christologische Einheit.” In Drei christologische Untersuchungen, 63-109. Berlin: De Gruyter.

Ayroulet, Elie (2013). De l'image à l'Image: Réflexions sur un concept clef de la doctrine de la divinisation de Saint Maxime le Confesseur. Rome: Institutum Patristicum Augustinianum.

Balás, David L. (1975). “The Idea of Participation in the Structure of Origen's Thought: Christian Transposition of a Theme of the Platonic Tradition." In Origeniana: Premier colloque international des études origéniennes, ed. Henri Crouzel, Gennaro Lomiento and Josep Rius-Camps, 257-275. Bari: Istituto di letteratura cristiana antica.

Garrigues, Juan-Miguel (1982). "Le dessein d'adoption du Créateur dans son rapport au Fils d'après s. Maxime le Confesseur." In Maximus Confessor: Actes du Symposium sur Maxime le Confesseur, ed. Felix Heinzer and Christoph Schönborn, 173-192. Fribourg: Éditions universitaires.

Gersh, Stephen (1978). From Iamblichus to Eriugena: An Investigation into the Prehistory and Evolution of the Pseudo-Dionysian Tradition. Leiden: Brill.

Greig, Jonathan (2017). "Proclus' Doctrine of Participation in Maximus the Confessor's Centuries of Theology I.48-50." Studia Patristica 75: 137-148.

Gurtler, Gary M. (2009). "Plotinus on the Limitation of Act by Potency." The Saint Anselm Journal 7: 1-15.

Harrison, Verna (1991). "Perichoresis in the Greek Fathers." St. Vladimir's Theological Quarterly 35: 53-65.

Larchet, Jean-Claude (1996). La divinisation de l'homme selon saint Maxime le Confesseur. Paris: Le Cerf.

Lévy, Antoine O.P. (2006). Le créé et l'incréé: Maxime le Confesseur et Thomas d'Aquin. Paris: Vrin.

Lloyd, Antony C. (1998). The Anatomy of Neoplatonism. Oxford: Oxford University Press.

Perl, Eric D. (1991). "Methexis: Creation, Incarnation, and Deification in Saint Maximus Confessor." Unpublished Ph.D. diss., Yale.

Portaru, Marius (2012). "The Vocabulary of Participation in the Works of Saint Maximus the Confessor." In Naboth's Vineyard, ed. Octavian Gordon and Alexandru Mihaila, 295-317. Cluj-Napoca: Presa Universitara Clujeana.

Sherwood, Polycarp O.S.B. (1964). "Survey of Recent Work on St. Maximus the Confessor." Traditio 20: 428-437.

Siorvanes, Lucas (1996). Proclus: Neo-Platonic Philosophy and Science. Edinburgh: Edinburgh University Press. 
Stemmer, Peter (1983). "PERICHORESE: Zur Geschichte eines Begriffs.” Archiv für Begriffsgeschichte 27: 9-55.

Thunberg, Lars (1995). Microcosm and Mediator: The Theological Anthropology of Maximus the Confessor. 2nd edition. Chicago: Open Court.

Tollefsen, Torstein T. (2001). "Did St Maximus the Confessor Have a Concept of Participation?" Studia Patristica 37: 618-625.

(2008). The Christocentric Cosmology of St Maximus the Confessor. Oxford: Oxford University Press.

(2012). Activity and Participation in Late Antique and Early Christian Thought. Oxford: Oxford University Press.

Uthemann, Karl-Heinz (1997). "Der Neuchalkedonismus als Vorbereitung des Monotheletismus: Ein Beitrag zum eigentlichen Anliegen des Neuchalkedonismus." Studia Patristica 29: 373-413.

Von Balthasar, Hans Urs (2003/1964'). Cosmic Liturgy: The Universe According to Maximus the Confessor. 2nd edition, trans. Brian E. Daley. S.J. San Francisco: Ignatius Press.

Wood, Jordan Daniel (2018). "Creation Is Incarnation: The Metaphysical Peculiarity of the Logoi in Maximus Confessor." Modern Theology 34.1: 82-102.

Zachhuber, Johannes (2015). "Christology after Chalcedon and the Transformation of the Philosophical Tradition: Reflections on a Neglected Topic." In The Ways of Byzantine Philosophy, ed. Mikonja Knezevic, 98-106. Alhambra: Sebastian Press. 
as what we can and cannot know belongs to a discussion of natures and causation it is much more a look into the past at how we came to be and the limitations of our nature. To talk of knowledge for Maximus, is to talk inescapably of relationship, love, freedom, and will - God is a who and can be known personally. For Proclus, these are ultimately all concepts that are incompatible with the oneness, simplicity, impassibility, and immovability of the One. Not only then is there a fundamental incompatibility between the philosophical positions of Proclus and Maximus on knowledge, but the very nature of the validity of such a comparison is called into question when their terminology and conceptions of the divine itself are so radically different.

\section{Notes}

1 Bathrellos 2013.

2 For a discussion of this in relation to Dionysius, see Pavlos' chapter on Theurgy in Dionysius the Areopagite, and Vasilakis' On the Meaning of Hierarchy in Dionysius the Areopagite, in this volume.

3 Proclus, El. theol. prop. 6. Hereafter the proposition number is used directly in the text.

4 Proclus, El. theol. prop. 50; Dodds 1963: 49.

5 Bathrellos 2013: 119.

6 E.g. Ps 90:2; Ps 102:27; Deut 6:4; Deut 33:27; Num 23:19; Isa 40:28.

7 Maximus, Th. oec. I.1, PG 90: 1084a; Berthold 1985: 129. Cf. also a passage very similar to Proclus' in identifying multiplicity as contrary to the simplicity of God (Th. oec. I.83, PG 90: 1118a-c). It is worth noting however, that a partner chapter opens the second century, clearly intended to mirror I.1, in which Maximus describes God as "entirely monad an entirely triad" and gives an extended section on the unity of the Trinity: Th. oec. II.1, PG 90: 1124d-1125c.

8 Maximus, Th. oec. I.10, PG 90: 1085d-1088a; Berthold 1985: 130.

9 Bathrellos 2013: 123-124.

10 Maximus, Amb. Th. 1.3, PG 91: 1036c; Louth 1996: 170.

11 Maximus, Amb. Io. 7.24, PG 91: 1085b; Constas 2014: 109. Although following this part of the sentence, Maximus goes on to say that God knows creatures according to His will, which, as we will come on to, is very different to Proclus' position.

12 Bathrellos 2013: 124.

13 Dodds 1963: 264. Dodds points to the passages: Plato, Leg. 903e, and Plotinus, Enn. IV.3.13 and 24.

14 When talking here and elsewhere about any deity "not willing" for Proclus, I mean that the activity has not been consciously willed, and that it occurs by necessity of nature. I do not mean that the activity is occurring against the will of the divine.

15 Tollefsen argues that for Proclus, although the cosmos has a first cause, it does not have a beginning in time, and thus the cosmos should not strictly be considered to have a beginning at all. See Tollefsen's chapter Proclus, Philoponus, and Maximus: The Paradigm of the World and Temporal Beginning, in this volume (p. 101).

16 Maximus, Amb. Io. 7.24, PG 91: 1085b-c; Constas 2014: 109.

17 Proclus tells us in prop. 167 that the Nous knows itself as one, and not as the multiple intelligences that it causes.

18 Maximus' use (Amb. Io. 7.24, PG 91: 1085a) of the word $\pi \rho 0 o p \iota \sigma \mu o$ (predeterminations), comes from Dionysius, $D N$ V.8, Suchla 1990: 188.8; PG 3: 824c.

19 Bathrellos 2013: 122-123.

20 God willing creation into being has providential importance not only for the reasons discussed here and below, but also because each creature is willed into being at their apportioned time, in accordance with the logoi intended for them. On this, see 
Tollefsen's chapter Proclus, Philoponus, and Maximus: The Paradigm of the World and Temporal Beginning, in this volume (p. 105).

21 Bathrellos 2013: 123.

22 Maximus, Th. oec. I.70, PG 90: 1110a; cf. 1 Cor 13:12. Here Maximus is likely building on the eschatological passage of Dionysius, DN I.4, Suchla 1990: 114.7-115.5; PG 3: $592 \mathrm{c}$.

23 Maximus, Amb. Io. 7.12-15, PG 91: 1077a-d; Constas 2014: 93.

24 Maximus, Amb. Io. 7.25, PG 91: 1088a; Bathrellos 2013: 124.

25 See Mateiescu's chapter The Doctrine of Immanent Realism in Maximus the Confessor, in this volume.

26 Maximus, Amb. Io. 7.29, PG 91: 1089c.

27 Maximus, Myst. ch. 5; Berthold 1985: 192.

28 Maximus, Amb. Io. 7.28, PG 91: 1089b; Constas 2014: 115. See also the passage quoted earlier from Maximus, Amb. Io. 7.12-14, PG 91: 1077a-b.

29 Blowers 1992: 162.

30 Maximus, $Q$. Thal., CCSG 22: 65.544-547.

31 Mitralexis 2014: 149.

32 Maximus Amb. Io. 7.9, PG 91: 1073b.

33 Maximus, Myst. ch. 23 and 24; for a discussion on the tension between acquiring divine virtue by free will and by grace in Maximus, see my doctoral thesis "Chapter 4: From Physical to Ethical in the Cosmos of St Maximus" (Brown Dewhurst 2017: 129-164).

34 It is the created order that proceeds from the Nous that we are in particular interested in, but we can to a certain extent refer to the One in this context also, since the One is the origin of all lesser deities, and does not "create" these by an act of will, but by its own good nature. Cf. Chlup 2012: 62-63.

35 Proclus, El. theol. prop. 122; Dodds 1963: 109.

36 Whilst this proposition specifically concerns the Henads, which are clearly distinct from the One (props. 21 and 116), Proclus in prop. 122 is defending "all that is divine"

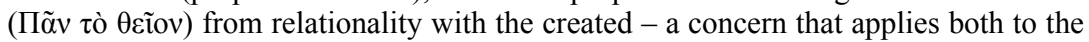
Henads and the One. Proclus also talks about the providence of the One in his De decem dubitationibus circa providentiam (Boese 1960: 4.4-25.)

37 Eg. See Maximus, Car. I.23-32, PG 90: 965a-968a.

38 Chlup 2012: 50.

39 Eg. Proclus, El. theol. prop. 8; Cf. Chlup 2012: 50-51.

40 Maximus, Th. oec. I.31, PG 90: 1093d-1096a; Berthold 1985: 134.

41 In passages like Th. oec. I.7, PG 90: 1085b we can see Maximus using a similar language to Proclus and calling God above all relation. However, this should be understood as referring to a difference between the unknowable divine nature and created nature. Relation with God becomes possible through Christ and the Spirit. Hence how we are able to participate in God at all when he is imparticipable. As I will come on to later, kataphatic and apophatic statements are not contradictory for Maximus, but necessary for describing the complexity of the relationship between God and His creation.

42 Maximus, Th. oec. II.36, PG 90: 1098a-b; Berthold 1985: 155.

43 According to Chlup, the innovation in thinking of the One in this way was a crucial step made by Plotinus, since prior to him, most Platonists were happy to talk of the Nous as the highest reality. Chlup 2012: 49.

44 Both in terms of referring to our reasoning faculties, and in terms of coming to know the logoi.

45 Natural contemplation is one of the stages of ascetic prayer Maximus adopts from Evagrios; it involves contemplating the logoi of creatures which are God's will for all things within all things. Cf. Louth 1996: 35-37.

46 Louth 1997: 42. 
47 Gregory Palamas, The Triads. The distinction between essence and energies allows for an understanding of God-in-Godself as beyond all comprehension (essence), whilst allowing for real encounter with God through His activity in the world (energies). God's energies truly are Him and thus to participate in them is to participate in God (since natures are known by their activity), but they do not circumscribe God's essence. God's essence is transcendent, whilst His energies are His imminent presence in the world.

48 Maximus, Myst. ch. 5; Berthold 1985: 192.

49 Maximus, Th. oec. I.9, PG 90: 1085c-d; Berthold 1985: 130.

50 Maximus, Amb. Io. 7.10-11, PG 91: 1076a-b.

51 Blowers 1992: 158-159.

\section{Bibliography}

\section{Primary sources}

\section{a. Editions}

Boese, Helmut (1960). "De decem dubitationibus circa providentiam.” In Procli Diadochi tria opuscula, 5-108. Berlin: De Gruyter.

Cantarella, Raffaele (ed.) (1931). "Mystagogia." In Massimo Confessore, La mistagogia ed altri scriti, 122-214. Florence: Testi Cristiani.

Dodds, Eric R. (ed.) $\left(1963^{2}\right)$. Proclus, The Elements of Theology. Oxford: Clarendon Press.

Laga, Carlos and Carlos Steel (eds.) (1980). Maximi Confessoris Ad Thalassium. CCSG. Vol. 22. Turnhout: Brepols.

Migne, Jacques-Paul (ed.) (1857). Dionysii Areopagitae, De Divinis Nominibus. PG. Vol. 3, cols. 586-996. Paris: Imprimerie Catholique.

(1865a). Maximi Confessoris Ambigua Liber sive de variis difficilibus locis SS. Dionysii Areopagitae et Gregorii Theologi. PG. Vol. 91, cols. 1031-1418. Paris: Imprimerie Catholique.

(1865b). Maximi Confessoris Capita de Charitate. PG. Vol. 90, cols. 959-1082. Paris: Imprimerie Catholique.

- (1865c). Maximi Confessoris Capita theologica et oeconomica. PG. Vol. 90, cols. 1083-1461. Paris: Imprimerie Catholique.

Suchla, Beate Regina (ed.) (1990). Corpus Dionysiacum I. Pseudo-Dionysius Areopagita, De Divinis Nominibus. PTS. Vol. 33. Berlin/New York: De Gruyter.

\section{b. Translations}

Berthold, George (trans.) (1985). Maximus the Confessor, Selected Writings. London: SPCK.

Constas, Nicholas (trans.) (2014). Maximus the Confessor, on Difficulties in the Church Fathers: The Ambigua. Vol. 1. Cambridge, MA: Harvard University Press.

Gendle, Nicholas (trans.) (1983). Gregory Palamas, The Triads. New Jersey: Paulist Press. Louth, Andrew (trans.) (1996). Maximus the Confessor. London: Routledge.

\section{Scholarly literature}

Bathrellos, Demetrios (2013). "Neo-Platonism and Maximus the Confessor on the Knowledge of God." In Studia Patristica Col. LVIII. Vol. 6: Neoplatonism and Patristics, ed. Markus Vinzent, 117-126. Leuven: Peeters. 
Blowers, Paul (1992). "Maximus the Confessor, Gregory of Nyssa, and the Concept of 'Perpetual Progress'." Vigiliae Christianae 46: 151-171.

Brown Dewhurst, Emma (2017). "Revolution in the Microcosm: Love and Virtue in the Cosmological Ethics of St Maximus the Confessor." Ph.D. diss., Durham.

Chlup, Radek (2012). Proclus: An Introduction. Cambridge: Cambridge University Press.

Louth, Andrew (1996). Maximus the Confessor. London: Routledge.

(1997). "Apophatic Theology and the Liturgy in St Maximos the Confessor." In Wisdom of the Byzantine Church: Evagrios of Pontos and Maximos the Confessor, 34-45. Columbia: University of Missouri.

Mitralexis, Sotiris (2014). Ever-Moving Repose: The Notion of Time in Maximus the Confessor's Philosophy through the Perspective of a Relational Ontology. Berlin: Deutschen Akademischen Austauschdienstes. Subsequently also published as Mitralexis, Sotiris (2018). Ever-Moving Repose: A Contemporary Reading of Maximus the Confessor's Theory of Time. Cambridge: James Clarke \& Co. 
Although a more in-depth study of the two lists of virtues is needed, I would submit that the Plotinian-Porphyrian teaching on the degrees of virtue is very likely the direct source of inspiration for the Pontic father.

Equally important is the possible connection between Plotinus, Porphyry, and Evagrius regarding the concept of "freedom from passion" ( $\dot{\alpha} \pi \dot{\alpha} \theta \varepsilon 1 \alpha)$. It has been customary since the studies of Antoine Guillaumont to explain the Evagrian term $\dot{\alpha} \pi \alpha \dot{\theta} \theta \varepsilon 1 \alpha$ as a very clear example of Stoic influence on his thought. ${ }^{50}$ In this case too, rather than searching for Stoic antecedents, I would suggest comparing Evagrius' use of the term with the extensive treatment of $\dot{\alpha} \pi \alpha \dot{\theta} \theta \varepsilon 1 \alpha$ in Plotinus' Enneads (esp. Enn. I.2. and III.6.) and in Porphyry's works.

From the comparison offered above between Evagrius' and Porphyry's theories, it has become clear that the two authors explain the formation of passions within the framework of Platonic psychology and of Platonic and Aristotelian epistemology and ethics. Consequently, it should be possible to explain freedom from passions in the exact same framework (and not on the basis of Stoic philosophy). To mention only one example, in Enn. I.2.5, 22-32, Plotinus likens the relationship between the irrational and the rational parts in a purified or "impassible" soul to a person who "lives next door to a sage" and gradually becomes like him. This comparison only makes sense in the framework of Plato's tripartite psychology, in which the "reasoning" of the two lower parts of the soul can be persuaded - by the mere presence of the purified reason - to follow their "master." This view of $\dot{\alpha} \pi \alpha \dot{\theta} \theta \varepsilon ı \alpha$, which differs in key points from Stoic impassibility, appears to be much closer to Evagrius' own Christian understanding of freedom from passions. This and all the points of comparison discussed in this chapter (perception, the origin of passions, the role of memory, opinion and imagination, the degrees of virtue, etc.) strongly suggest that a thorough re-evaluation of Evagrius' complex relationship with Stoicism and Late Antique Platonism is needed.

\section{Notes}

1 I wish to thank the organisers of the workshop "Platonism and Christian Thought in Late Antiquity" (Oslo, December 1-3, 2016) and the editors of this volume for the opportunity to present the results of my research. I am especially grateful to Prof. Eyólfur Kjalar Emilsson (Oslo) and to Michael Krewet (Berlin) for their useful comments on an earlier draft of this chapter.

2 I have used the following abbreviations for Evagrius' works: Cogit. = De malignis cogitationibus, ed. Géhin, Guillaumont and Guillaumont 1998; Disc. = Capita cic auctoribus discipulis Euagrii, ed. Géhin 2007; Eulog. = Tractatus ad Eulogium, ed. Fogielman 2017; Gnost. = Gnosticus, ed. Guillaumont and Guillaumont 1989; $K G=$ Kephalaia Gnostika, ed. Guillaumont 1958; Oct. Spir. = De octo spiritibus malitiae (PG 79: 1145-1164); Or. = De oratione, ed. Géhin 2017; Pract. $=$ Practicus, ed. Guillaumont and Guillaumont 1971; Schol. Iob = Scholia in Iob, ed. Hagedorn and Hagedorn 1994-2000; Schol. Prov. = Scholia in Prouerbia, ed. Géhin 1987; Schol. Ps. $=$ Scholia in Psalmos, ed. Pitra 1876-1891.

3 See, above all, von Balthasar 1961-1969: 1, 256-273, 352-267.

4 See the numerous studies of Father Gabriel Bunge (most recently: Bunge 2004, 2010). Among the recent monographs which argue for the orthodox Christian character of Evagrius' thought, one could mention Dysinger 2005, Corrigan 2009, and Casiday 2013. 
5 See Joest 1993; Tobon 2010.

6 Hieronymus, Epistula 133; PL 22: 1151.

7 Guillaumont and Guillaumont 1971: 100; Guillaumont 2004; Sorabji 2000: 357-371. See also Knuuttila 2004: 140-144.

8 Following Aristotle, EN X.7.1-3, 1177a12-27. See e.g. Porphyry, Sent. 32; Dillon, in Brisson 2005: 812. Evagrius, Or. 35 and 86, where Evagrius connects intellection and contemplation with pure prayer.

9 Porphyry, De abst. I.30.6-7; Clark 2000: 42.

10 In De abst. I.30.2 and in Sent. 4 Porphyry similarly speaks about an inclination ( $\dot{\rho} \circ \pi \eta$ ) towards bodies generated by the intelligible as a secondary power (Brisson 2005: 387).

11 Porphyry, De abst. I.29.4; Clark 2000: 41-42.

12 Porphyry, De abst. I.31.1; Clark 2000: 43, modified.

13 Géhin 2012.

14 Bunge 1989 has rightly stressed the need to interpret this expression within its Christian context. For the purpose of this study, I will however focus on its evident links with Porphyry.

15 Evagrius, Or. 110; Sinkewicz 2003: 205, modified.

16 Aristotle, EN X.7.9, 1178a 6-7.

17 For an in-depth discussion of Evagrius' anthropology and the role of the nous, see Tobon 2010: 15-89.

18 Guillaumont and Guillaumont 1971: 618-621.

19 Porphyry, Sent. 8-9; Dillon, in Brisson 2005: 796-797.

20 Evagrius, Pract. 52; Sinkewicz 2003: 106-107.

21 See e.g. Plotinus, Enn. I.1.1-4.

22 Porphyry, De abst. I.33, 2-6; Clark 2000: 43-44, slightly modified.

23 Porphyry, Comm. in Ptol. Harm.; Düring 1932: 13.19-14.14. For an English translation of the passage, see Barker 2015: 88-91. On the epistemology of the passage, see Tarrant 1993: 108-147; Chase 2010.

24 While older scholarship insisted on the "passive-receptive" nature of perception in Aristotle, new studies emphasise more and more the "active" nature of $\alpha$ il $\sigma \theta \eta \sigma 1 \varsigma$ in Aristotle's philosophy. For a recent overview, see Corcilius 2014. Two pioneering studies in this sense are Ebert 1983 and Bernard 1988. A comprehensive study on the nature of emotions in Aristotle, which fully takes into account Aristotle's epistemology and theory of perception, is offered by Krewet 2011.

25 Aristotle, EN X.4.4, $1174 \mathrm{~b} 14$.

26 Aristotle, EN X.4.8, 1174b31-33.

27 Porphyry, Sent. 1; Dillon, in Brisson 2005: 798.

28 Porphyry, De abst., I.34.7; Clark 2000: 44.

29 Cf. also Aristotle, EN II.5.1-2, 1105b21-24: "By passions I mean desire, anger, fear, confidence, envy, joy, friendship, hatred, longing, jealousy, pity, and in general that which is accompanied by pleasure and pain". See also Plato, Tim. 42a-b.

30 For a thorough discussion of envy ( $\varphi$ Oóvo $)$ ), see Plato, Phileb. 48b-50a.

31 Evagrius, Eulog. 23; Sinkewicz 2003: 49, modified.

32 Evagrius, Pract. 35; Sinkewicz 2003: 104. The importance of these passages for Evagrius' teaching on passions has already been pointed out by Antoine Guillaumont 2004: 208-209, and Monica Tobon 2010: 144.

33 Evagrius, Pract. 4; Sinkewicz 2003: 97.

34 Evagrius, Oct. Spir. 11, PG 79: 1156d. See Tobon 2010: 143.

35 See e.g. Evagrius, Schol. Prov. 4 (Géhin 1987: 94); Schol. Iob 9.32-33 (Hagedorn and Hagedorn 1994-2000: 2, 104-105). For the question of authorship of the Scholia in Iob, see Casiday 2006: 123-124, 224.

36 Evagrius, Schol. Ps. (Pitra 1876-1891: 3, 234), cf. KG I.36 (Guillaumont 1958: 32-35), $K G$ II.83 (Hausherr 1939: 230). See further Alexander, De anima liber cum mantissa 39.4-5, Themistius, Paraphrasis in libros Aristotelis de anima 78.10-11. 


\section{Adrian Pirtea}

37 Evagrius, Pract. 34; Sinkewicz 2003: 103.

38 Evagrius, Cogit. 2; Sinkewicz 2003: 154.

39 Sorabji 2000: 343-356.

40 For a discussion of Seneca's concept of emotions, see Krewet 2013: 133-140.

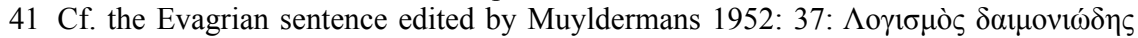

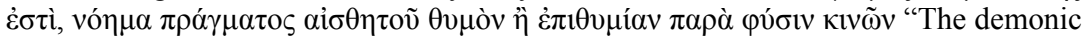
thought is the mental representation of a sensible object which moves the irascible or the appetitive (part) against nature."

42 Evagrius, Pract. 74-75; Sinkewicz 2003: 110.

43 Gibbons 2015.

44 See Aristotle, EN, II.1, 1103a14-1103b25, and Krewet 2013: 174-181.

45 See Porphyry, De abst. I.29.5-6; Evagrius, Gnost. 45.

46 On this topic, see Dillon 1983, Thiel 2001. I thank Wolfgang Hoyer for this reference.

47 Porphyry, Sent. 32; Dillon, in Brisson 2005: 810-812.

48 Guillaumont and Guillaumont 1971: 680-689; Guillaumont and Guillaumont 1989: $172-177$.

49 Guillaumont and Guillaumont 1989: 175.

50 Guillaumont and Guillaumont 1971: 100.

\section{Bibliography}

\section{Primary sources}

\section{a. Editions}

Barker, Andrew (ed.) (2015). Porphyry's Commentary on Ptolemy's Harmonics: A Greek Text and an Annotated Translation. Cambridge: Cambridge University Press.

Basore, John W. (ed.) (1928). L. Annaeus Seneca, Moral Essays, vol. 1: De Providentia, de Constantia, de Ira, de Clementia. Cambridge, MA: Heinemann.

Bouffartigue, Jean and Michel Patillon (eds.) (1977-1995). Porphyre, De l'abstinence. Paris: Les Belles Lettres.

Brisson, Luc (ed.) (2005). Porphyre: Sentences. Études d'introduction, texte grec et trad. française, commentaire par UPR $76 d u$ CNRS. Paris: Vrin.

Bruns, Ivo (ed.) (1887). Alexandri Aphrodisiensis praeter Commentaria scripta minora: De anima liber cum mantissa (CAG, Suppl. II/1). Berlin: Reimer.

Burnet, John (ed.) (1900-1907). Platonis Opera. Oxford: Oxford University Press.

Bywater, Ingram (ed.) (1894). Aristotle's Ethica Nicomachea. Oxford: Clarendon Press.

Düring, Ingemar (ed.) (1932). Tyrius Porphyrius, Kommentar zur Harmonielehre des Ptolemaios. Göteborg: Elander.

Fogielman, Charles-Antoine (ed.) (2017). Évagre le Pontique, À Euloge: Les vices opposés aux vertus. Paris: Le Cerf.

Géhin, Paul (ed.) (1987). Évagre le Pontique, Scholies aux Proverbes. Paris: Le Cerf. (2007). Évagre le Pontique, Chapitres des disciples d'Évagre. Paris: Le Cerf. (2017). Évagre le Pontique, Chapitres sur la prière. Paris: Le Cerf.

Géhin, Paul, Claire Guillaumont and Antoine Guillaumont (eds.) (1998). Évagre le Pontique: Sur les pensées. Paris: Le Cerf.

Guillaumont, Antoine (ed.) (1958). Les six centuries des 'Kephalaia gnostica': Édition critique de la version syriaque commune et édition d'une nouvelle version syriaque, intégrale, avec une double traduction française. Paris: Firmin-Didot.

Guillaumont, Antoine and Claire Guillaumont (eds.) (1971). Évagre le Pontique, Traité pratique, ou Le Moine. Paris: Le Cerf. 
(1989). Évagre le Pontique, Le gnostique. Paris: Le Cerf.

Hagedorn, Ursula and Dieter Hagedorn (eds.) (1994-2000). Die älteren griechischen Katenen zu Hiob. Berlin: De Gruyter.

Heinze, Richard (ed.) (1899). "Themistii in libros Aristotelis de anima paraphrasis." In CAG. Vol. 3. Berlin: Reimer.

Henry, Paul and Hans-Rudolf Schwyzer (eds.) (1951-1973). Plotini Opera. Paris: Brouwer/ Bruxelles: Éd. Universelle.

Migne, Jacques-Paul (ed.) (1845). Patrologiae Cursus Completus Series Latina, Tomus XXII: Sancti Eusebii Hieronymii Opera Omnia. Paris: Imprimerie Catholique.

Muyldermans, Joseph (ed.) (1952). Evagriana Syriaca: Textes inédits du British Museum et de la Vaticane, édités et traduits. Louvain: Publications Universitaires/ Institut Orientaliste.

Pitra, Jean-Baptiste (ed.) (1876-1891). Analecta Sacra (et classica) Spicilegio Solesmensi parata. Paris: Jouby and Roger.

\section{b. Translations}

Clark, Gillian (trans.) (2000). Porphyry, on Abstinence from Killing Animals. London: Duckworth.

Sinkewicz, Robert E. (trans.) (2003). Evagrius of Pontus, the Greek Ascetic Corpus. Oxford: Oxford University Press.

\section{Scholarly literature}

Bernard, Wolfgang (1988). Rezeptivität und Spontaneität der Wahrnehmung bei Aristoteles. Versuch einer Bestimmung der spontanen Erkenntnisleistung der Wahrnehmung bei Aristoteles in Abgrenzung gegen die rezeptive Auslegung der Sinnlichkeit bei Descartes und Kant. Baden-Baden: Verlag Valentin Koerner.

Bunge, Gabriel (1989). "Nach dem Intellekt Leben: Zum sog. 'Intellektualismus' der evagrianischen Spiritualität." In Simandron: Der Wachklopfer; Gedenkschrift für Klaus Gamber (1919-1989), ed. Wilhelm Nyssen, 95-109. Köln: Luthe-Verlag.

(2004). Akedia: Die geistliche Lehre des Evagrios Pontikos vom Überdruss. Würzburg: Der Christliche Osten.

(2010). 'In Geist und Wahrheit': Studien zu den 153 Kapiteln Über das Gebet des Evagrios Pontikos. Bonn: Borengässer.

Casiday, Augustine (2006). Evagrius Ponticus. London/New York: Routledge.

(2013). Reconstructing the Theology of Evagrius Ponticus: Beyond Heresy. Cambridge: Cambridge University Press.

Chase, Michael (2010). "Porphyry on the Cognitive Process." Ancient Philosophy 30: 383-405.

(2018). "Porphyry." In Brill's Companion to the Reception of Plato in Antiquity, ed. Harold Tarrant, Danielle A. Layne, Dirk Baltzly and François Renaud, 336-350. Leiden: Brill.

Corcilius, Klaus (2014). "Activity, Passivity, and Perceptual Discrimination in Aristotle." In Active Perception in the History of Philosophy: From Plato to Modern Philosophy, ed. José F. Silva and Mikko Yrjönsuuri, 31-53. Cham/Heidelberg/New York/Dordrecht/ London: Springer.

Corrigan, Kevin (2009). Evagrius and Gregory: Mind, Soul, and Body in the 4th Century. Farnham/Burlington: Ashgate. 
Dillon, John (1983). "Plotinus, Philo and Origen on the Grades of Virtue." In Platonismus und Christentum. Festschrift für Heinrich Dörrie, ed. Horst-Dieter Blume and Friedhelm Mann, 92-105. Münster: Aschendorff.

Dysinger, Luke (2005). Psalmody and Prayer in the Writings of Evagrius Ponticus. Oxford: Oxford University Press.

Ebert, Theodor (1983). "Aristotle on What Is Done in Perceiving." Zeitschrift für Philosophische Forschung 37: 181-198.

Géhin, Paul (2012). “À propos d'une expression des Chapitres sur la prière d'Évagre: 'Vis selon l'intellect'." In Byzantine Theology and Its Philosophical Background, ed. Antonio Rigo, 17-31. Turnhout: Brepols.

Gibbons, Kathleen (2015). "Passions, Pleasures, and Perceptions: Rethinking Evagrius Ponticus on Mental Representation." Zeitschrift für Antike und Christentum 19.2: 297-330.

Guillaumont, Antoine (2004). Un philosophe au désert: Évagre le Pontique. Paris: Vrin.

Hausherr, Irenée (1939). "Nouveaux fragments grecs d'Évagre le Pontique." Orientalia Christiana Periodica 5: 229-233.

Joest, Christoph (1993). "Die Bedeutung von Akedia und Apatheia bei Evagrios Pontikos." Studia Monastica 35.1: 7-53.

Knuuttila, Simo (2004). Emotions in Ancient and Medieval Philosophy. Oxford: Clarendon Press.

Krewet, Michael (2011). Die Theorie der Gefühle bei Aristoteles. Heidelberg: Universitätsverlag Winter.

- (2013). Die stoische Theorie der Gefühle: Ihre Aporien, ihre Wirkmacht. Heidelberg: Universitätsverlag Winter.

Ramelli, Ilaria (2018). "From Origen to Evagrius." In Brill's Companion to the Reception of Plato in Antiquity, ed. Harold Tarrant, Danielle A. Layne, Dirk Baltzly and François Renaud, 271-291. Leiden: Brill.

Sorabji, Richard (2000). Emotion and Peace of Mind: From Stoic Agitation to Christian Temptation: The Gifford Lectures. Oxford: Oxford University Press.

Tarrant, Harold (1993). Thrasyllan Platonism. Ithaca/London: Cornell University Press.

Thiel, Rainer (2001). "Philosophie als Bemühung um Sterben und Tod. Tugendlehre und Suizidproblematik bei Platon und den Neuplatonikern." Antike und Abendland 47: 21-40.

Tobon, Monica (2010). "Apatheia in the Teachings of Evagrius Ponticus." PhD dissertation, London: University College London.

Von Balthasar, Hans Urs (1961-1969). Herrlichkeit: Eine theologische Ästhetik. Einsiedeln: Johannes Verlag. 


\section{Tomas Ekenberg}

One thing is clear. Happiness is not simply bodily pleasure. If an Epicurean were to suggest that pleasure is exclusively the result of satisfaction of bodily desires, then of course Augustine thinks there are other, nobler kinds of pleasure. ${ }^{19}$ There are higher and better kinds of joy. But Augustine and Epicurus both agree that happiness is, from the human point of view, a state of mind. And happiness is, for humans, the ultimate end and the best and highest and most valuable good.

Hence, to the extent that Augustine is - let's say - a "classical" eudaimonist, he is more Epicurean than Stoic. All things considered he is of course neither, but a Christian eudaimonist. In placing Augustine in the Epicurean camp we have had to bracket the other-worldly aspects of Augustine's philosophy. Now if I am right, then a careful, unambiguous assessment of Augustine's position must take into account our own stance on those fundamental issues, which underpin his entire take on moral philosophy. If we place ourselves among the believers, then what Augustine lays out is simply and straightforwardly an (or perhaps "the") eudaimonist Christian ethics. If not, his mature position is best described as that of a confused and mistaken Epicurean. In any case, his view is eudaimonist.

The temptation for an interpreter who applies the perspective of the non-believer is to over-emphasise Augustine's downgrading of pleasure, or physical pleasure in particular. Paired with the assumption that such "contempt of the flesh" should put him in stark opposition with hedonism (an assumption which, treated with care, is correct) leads to the defective conclusion that he must favor some version of the Stoic notion of the supreme and intrinsic value of virtue. Whereas from Augustine's own perspective, the Stoic view is deficient in precisely the same way as the Epicurean: "It may be supposed that the Stoics live 'by the rule of the spirit,' because they place man's highest good in the mind; and what is man's mind, but spirit? But in fact both [Epicureans and Stoics] live 'by the rule of the flesh,' as divine Scripture uses the expression." ${ }^{20}$ Happiness is the sole ultimate goal of moral action and life. The task of the moral philosopher is the elucidation of the principles or conditions of the happy life. The Stoic collapses the two concepts of happiness and virtue completely. Being virtuous is being happy. For the Epicurean, virtue, and happiness - i.e. pleasure or well-being - are distinct, and the former is a means to the latter. For Augustine too, virtue is a means, but happiness is the direct and unmediated communion with God, a relationship which is identical to a state of perfect bliss.

\section{Notes}

1 Wolterstorff 2014.

2 Tornau 2015. See also Rist 2015, where Wolterstorff's interpretation is critically assessed. A comprehensive overview of Augustine's ethics can be found in Kent 2001.

3 This is not to claim that Augustine considered all kinds of self-serving behavior morally unproblematic or morally indifferent. There are different kinds of self-love, the mature Augustine explains. Among these, only some are consistent with moral motivation, whereas others are clearly pathological and evil. See e.g. O'Donovan's careful discussion in his 1980 .

4 Frede 2011 argued that Augustine's notion of the will in De libero arbitrio can be more or less directly traced back especially to Stoic antecedents. Consequently, 
Augustine's moral-psychological outlook as a whole should be seen as closely related to that of earlier, pagan philosophers. For a detailed study of Augustine's engagement with Stoic ideas also in his mature works, see Byers 2011.

5 Augustine, Lib. arb. 1.12.25 (CCSL 29, 227): "Voluntas, qua adpetimus recte honesteque uiuere et ad summam sapientiam peruenire."

6 For critique of the interpretation that Augustine's own conception of moral progress is consonant with the Neoplatonists' notion of ascent, see Williams 2002 and King 2014. I return to the issue of Augustine's relation to Stoic ethics below.

7 See e.g. Augustine, Trin. 13.4.7 (CCSL 50A, 390-391) for the claim that all human beings will to be happy - and should so will - in the context of Augustine's mature approach to ethics.

8 Annas 1995: 36-42.

9 Annas 1995: 45.

10 Wolterstorff 2014: 48-49.

11 Augustine, Conf. 10.22.32 (CCSL 27, 172), quoted in Wolterstorff 2014: 52. The translation is by R. S. Pine-Coffin in Augustine, Confessions (London: Penguin, 1984, reprint of 1961). "Absit, domine, absit a corde serui tui, qui confitetur tibi, absit, ut, quocumque gaudio gaudeam, beatum me putem. Est enim gaudium, quod non datur impiis, sed eis, qui te gratis colunt, quorum gaudium tu ipse es. Et ipsa est beata uita, gaudere ad te, de te, propter te: ipsa est et non est altera. Qui autem aliam putant esse, aliud sectantur gaudium neque ipsum uerum. Ab aliqua tamen imagine gaudii uoluntas eorum non auertitur."

12 Augustine, Lib. arb. 1.13.29 (CCSL 29, 230-231). “A. Hanc igitur uoluntatem si bona itidem uoluntate diligamus atque amplectamur rebusque omnibus, quas retinere non quia uolumus possumus, anteponamus, consequenter illae uirtutes, ut ratio docuit, animum nostrum incolent, quas habere id ipsum est recte honesteque uiuere. Ex quo conficitur ut, quisquis recte honesteque uult uiuere, si id se uelle prae fugacibus bonis uelit, adsequatur tantam rem tanta facilitate, ut nihil aliud ei quam ipsum uelle sit habere quod uoluit. E. Vere tibi dico, uix me contineo quin exclamem laetitia, repente mihi oborto tam magno et tam in facili constituto bono. A. Atqui hoc ipsum gaudium quod huius boni adeptione gignitur, cum tranquille et quiete atque constanter erigit animum, beata uita dicitur; nisi tu putas aliud esse beate uiuere quam ueris bonis certisque gaudere."

13 For an illuminating discussion of different ancient approaches to the relation between happiness and time (and so between ethics and the conception of a life as a whole), see Emilsson 2015.

14 Augustine, Conf. 6.16.26 (CCSL 27, 90). "Nec me reuocabat a profundiore uoluptatum carnalium gurgite nisi metus mortis et futuri iudicii tui, qui per uarias quidem opiniones, numquam tamen recessit de pectore meo. Et disputabam cum amicis meis Alypio et Nebridio de finibus bonorum et malorum Epicurum accepturum fuisse palmam in animo meo, nisi ego credidissem post mortem restare animae vitam et tractus meritorum, quod Epicurus credere noluit."

15 Ibid. (CCSL 27, 90-91). "[I]ta demersus et caecus cogitare non possem lumen honestatis et gratis amplectendae pulchritudinis, quam non uidet oculus carnis, et uidetur ex intimo." As it turns out, the relation between the physical or bodily aspect of a human being and Augustine's Pauline notion of the flesh is a tricky matter. I return to this issue below, in the concluding remarks.

16 Augustine, Conf. 6.16.26 (CCSL 27, 90) "Et quaerebam, si essemus inmortales et in perpetua corporis uoluptate sine ullo amissionis terrore uiueremus, cur non essemus beati aut quid aliud quaereremus."

17 "And further, how will that opinion be true, which has been so tried, and sifted, and thoroughly strained, and is so certain, viz. that all men will to be blessed, if they themselves who are already blessed neither will nor do not will to be blessed? Or if they will it, as truth proclaims, as nature constrains, in which indeed the supremely good and 
unchangeably blessed Creator has implanted that will: if, I say, they will to be blessed who are blessed, certainly they do not will to be not blessed. But if they do not will not to be blessed, without doubt they do not will to be annihilated and perish in regard to their blessedness. But they cannot be blessed except they are alive; therefore they do not will so to perish in regard to their life. Therefore, whoever are either truly blessed or desire to be so, will to be immortal. But he does not live blessedly who has not that which he wills. Therefore it follows that in no way can life be truly blessed unless it be eternal." (See CCSL 50A, 397-398.).

18 See Trin. 13.7.10 (CCSL 50A, 395).

19 Is there, though, any reason to think that the special kind of pleasure which Epicureans pursue - the pleasure that is identified with the absence of all pain - is there any reason to call this pleasure a pleasure of the body? Of this I am not convinced.

20 Augustine, Civ. Dei 14.2 (CCSL 48, 415). "Stoicis autem, qui summum bonum hominis in animo ponunt, secundum spiritum uiuere, quia et hominis animus quid est nisi spiritus? Sed sicut loquitur scriptura diuina, secundum carnem uiuere utrique monstrantur." Trans. Bettenson 2004.

\section{Bibliography}

\section{Primary sources}

\section{a. Editions}

Dombart, Bernhard and Alfons Kalb (eds.) (1955). Sancti Aurelii Augustini De civitate Dei. CCSL. Vols. 47-48. Turnhout: Brepols.

Green, William M. (ed.) (1970). Sancti Aurelii Augustini De libero arbitrio. CCSL. Vol. 29. Turnhout: Brepols.

King, Peter (ed. and trans.) (2010). Augustine, on the Free Choice of the Will, on Grace and Free Choice, and Other Writings. Cambridge: Cambridge University Press.

Mountain, William John and Frater Glorie (eds.) (1968). Sancti Aurelii Augustini De trinitate libri XV. CCSL. Vols. 50-50A. Turnhout: Brepols.

O'Donnell, James J. (1992). Confessions. Latin Text and Commentary. 3 vols. Oxford: Clarendon Press.

Verheijen, Luc (ed.) (1981). Sancti Aurelii Augustini Confessionum libri XII. CCSL. Vol. 27. Turnhout: Brepols.

\section{b. Translations}

Bettenson, Henry (trans.) (2004). Augustine of Hippo, City of God. New York: Penguin.

Hill, Edmund (trans.) (2012). Saint Augustine, the Trinity (De trinitate). 2nd edition. Hyde Park, NY: New City Press.

Pine-Coffin, Richard Sydney (trans.) (1984). Saint Augustine, Confessions. London: Penguin.

Sheed, Francis Joseph (trans.) (1993). Augustine, Confessions. Indianapolis/Cambridge: Hackett Publishing Company.

\section{Scholarly literature}

Annas, Julia (1995). The Morality of Happiness. Oxford: Oxford University Press.

Byers, Sarah Catherine (2011). Perception, Sensibility, and Moral Motivation in Augustine: A Stoic-Platonic Synthesis. Cambridge: Cambridge University Press. 
Emilsson, Eyjólfur K. (2015). “Ancient Philosophers on Happiness and Time.” In The Quest for the Good Life: Ancient Philosophers on Happiness, ed. Øyvind Rabbås, Eyjólfur K. Emilsson, Hallvard Fossheim and Miira Tuominen, 222-240. Oxford: Oxford University Press.

Frede, Michael (2011). A Free Will: Origins of the Notion in Ancient Thought. Berkeley: University of California Press.

Kent, Bonnie (2001). “Augustine's Ethics.” In The Cambridge Companion to Augustine, ed. Eleonor Stump and Norman Kretzmann, 206-234. Cambridge: Cambridge University Press.

King, Peter (2014). “Augustine's Anti-Platonist Ascents.” In Augustine's Confessions: Philosophy in Autobiography, ed. William E. Mann, 6-27. Oxford: Oxford University Press.

O’Donovan, Oliver (1980). The Problem of Self-Love in St. Augustine. Eugene, OR: Wipf \& Stock Publishers.

Rist, John (1999). "Moral Motivation in Plato, Plotinus, Augustine, and Ourselves." In Plato and Platonism, ed. Johannes M. Van Ophuijsen, 261-277. Washington, DC: Catholic University of America Press.

- (2015). Review of William Mann (ed.), Augustine's Confessions: Philosophy in Autobiography. Notre Dame Philosophical Reviews. URL: https:/ndpr.nd.edu/news/ augustine-s-confessions-philosophy-in-autobiography/

Tornau, Christian (2015). “Happiness in this Life?" In The Quest for the Good Life: Ancient Philosophers on Happiness, ed. Øyvind Rabbås, Eyjólfur K. Emilsson, Hallvard Fossheim and Miira Tuominen, 265-280. Oxford: Oxford University Press.

Williams, Thomas (2002). "Augustine vs Plotinus: The Uniqueness of the Vision at Ostia." In Medieval Philosophy and the Classical Tradition in Islam, Judaism, and Christianity, ed. John Inglis, 169-179. New York: Curzon Press.

Wolterstorff, Nicholas (2014). "Happiness in Augustine's Confessions." In Augustine's Confessions: Philosophy in Autobiography, ed. William E. Mann, 46-70. Oxford: Oxford University Press. 